Portland State University

PDXScholar

\title{
Making Room for Roses: the 1911 Relocation of the Multnomah County Poor Farm
}

Kira Helene Lesley

Portland State University

Follow this and additional works at: https://pdxscholar.library.pdx.edu/open_access_etds

Part of the History Commons

Let us know how access to this document benefits you.

\section{Recommended Citation}

Lesley, Kira Helene, "Making Room for Roses: the 1911 Relocation of the Multnomah County Poor Farm" (2018). Dissertations and Theses. Paper 4355.

https://doi.org/10.15760/etd.6248

This Thesis is brought to you for free and open access. It has been accepted for inclusion in Dissertations and Theses by an authorized administrator of PDXScholar. Please contact us if we can make this document more accessible: pdxscholar@pdx.edu. 
Making Room for Roses: The 1911 Relocation of the Multnomah County Poor Farm

\author{
by \\ Kira Helene Lesley
}

A thesis submitted in partial fulfillment of the

requirements for the degree of

Master of Arts

in

History

Thesis Committee:

Catherine McNeur, Chair

Katrine Barber

David Johnson

Carl Abbott

Portland State University

2018 
(C) 2018 Kira Lesley 


\begin{abstract}
From 1868 to 1911, the Multnomah County Poor Farm off Canyon Road in the Tualatin Hills housed indigent and sick residents of Portland and surrounding areas. In 1911, county officials relocated the Poor Farm from the West Hills flanking Portland to the far eastern portion of the county. Subsequently, the site hosted a municipal golf course and is currently home to the Oregon Zoo and Hoyt Arboretum. With no physical presence left, the original Poor Farm was quickly forgotten, and the reasons for its relocation have been obscured by the passage of time. Occasional references to the farm in newspapers and blogs retell the same story, that county authorities relocated the farm after a 1910 visit by charity organizations revealed atrocious living conditions. In reality, the county had begun scouting land for the new farm two years prior to the charity visit and ensuing newspaper exposé. ${ }^{1}$
\end{abstract}

Conditions at the farm in 1910 may have been bad, but the relocation was not a product of altruism alone. More important was Portland's striving for greatness in the opening of the twentieth century. The early 1900s were heady times for West Coast cities, and as the century opened, Portland was still the largest city in the Northwest and the regional hub for shipping and commerce. A massive development boom, coupled with Progressive-Era reforms around parks and public health, worked to reshape the face of Portland's physical landscape. As the city grew and local boosters sought to promote

1 "Proposals Invited," in Special Notices, Oregonian, April 28, 1909; "Poor Farm on East Side," Oregonian. July 9, 1908. The Oregonian reported that the county commissioners were looking for a new poor farm location in 1908. The newspaper also ran an announcement in April 1909 that the county would soon begin accepting bids for the Poor Farm land on Canyon Road in June 1909. The indictment by visiting charity groups did not occur until November of 1910, more than a year after the county began advertising for bids. 
its image as a prosperous and beautiful metropolis, some leading Portlanders began to see the Poor Farm as a blight on their city. With land becoming more expensive and less available, Portlanders contested who had the right to which parcels and for which purposes. Real estate, public health, and general development fervor combined to make the Poor Farm land seem undeserving of its location. As Portland looked towards its future, Portlanders' desire to create a great city resulted in the displacement of the Poor Farm and its inhabitants to the county's physical and psychological fringes. 


\section{Dedication}

This work is dedicated to the inhabitants of the Multnomah County Poor Farm and Hospital, in solidarity with the forgotten peoples of the world. 


\section{Acknowledgements}

I would like to acknowledge the hard-working, dedicated professors and staff of the Portland State University History Department. Professor David Johnson encouraged me to pursue this topic, as well as other ideas and paths of historical inquiry that I did not intend to follow. His classes, his support, and his conversation, have invigorated my academic life for several years. Professor Catherine McNeur has been a source of inspiration and motivation since taking over from Professor Johnson as my thesis advisor. I have always known I could count on her for help and guidance. She has been an engaged advisor who is ready and willing to help with everything from suggesting pertinent resources and further readings to signing and submitting paperwork for me when I let it get down to the wire. In addition, Professor McNeur has helped me improve my writing, working with me on brevity and structure. I respect and have learned tremendously from her insistence on high quality writing.

I would also like to acknowledge Professor Garrison for being an engaged and responsive chair, in addition to an excellent professor. He always works to support students and I have benefitted greatly from his help with scholarship applications, paperwork, and all those practical details that are so important to successful completion of a degree. The same is true for Jeff Brown and Andrea Janda, who have both been kind, courteous and patient with my multitudinous questions over my years at Portland State.

I would also like to acknowledge the other professors I have had in the PSU History department, all of whom sparked my interest in a different facet of the discipline: Professor James Grehan, whose classes in Middle East history gave me a new perspective 
on issues I had studied as a Religious Studies major before transferring to PSU and informed my understanding of current politics, Professor Patricia Schechter, whose classes made me realize how interested I was in the theory and practice of public history, and Professor Katrine Barber, whose excitement for Oregon history and doing the work of public history are contagious. In addition, Dr. Jennifer Schuberth was an exceptional professor and a source of support inside and outside academia. I would also like to acknowledge the late Professor Ann Fulton, who, in addition to being an excellent professor, extended compassion and kindness at a very difficult time in my life. Last but not least, I would like to thank my family. My grandparents, Peter and Helen Stavrakis, enriched my life with stories of their experiences as refugees from the Soviet Union. My grandmother Hazel Lange was a legend for her tours of small western towns, and she passed on to me her love of this region. My mother and father nourished my interest in history by exposing my sister and me to new places, when they could have left us at home. Exploring Oregon ghost towns has left an especially deep impression on me. My sister Elena has always provided an aspirational example of a scholar in my eyes, someone who is brave, compassionate, and altruistic. As the older sister, she has been the trailblazer, and she is generous enough to share her experience and knowledge with me.

Finally, my partner Annie is my biggest source of support. She is my partner in every sense of the word, and she has heard me talk about this research, and attended more of my presentations, than anyone. Annie's unflinching belief in my abilities, and her love, have given me motivation to keep working through challenges and blessings. God 
willing, I look forward to encountering many more of both, together with her. 
Table of Contents
Abstract
i-ii.
Dedication
iii.
Acknowledgements
iv-vi.
List of Figures
viii.
Introduction: Forgotten Bones
$1-3$.
Chapter One: The Deserving Poor Revisited
Chapter Two: Parks, Poverty, and Public Good
$30-49$.
Chapter Three: The Boom Years
$50-74$
Chapter Four: Paupers, Lepers and the Pest House
75-103.
Epilogue
104-108.
Archival Sources
109-110.
Bibliography
111-114. 


\section{List of Figures}

Figure 1. Multnomah County Poor Farm on Canyon Road, Rear View _.. page 10

Figure 2. Multnomah County Poor Farm on Canyon Road, Front View $\ldots$ page 15

Figure 3. Olmsted Plan for a System of Parks and Boulevards, as envisioned by The Oregonian, June 12, 1904

. . page 40

Figure 4. Contour Map of Sliding Lands Near Poor Farm and City Park

.. p page 41

Figure 5. Portland Blue Map with Olmsted Sketches

.. p page 42

Figure 6. Portland Blue Map with Olmsted Sketches, Enlarged Section

.. p page 43

Figure 7. Photo from Portland Heights, 1903

... page 59

Figure 8. Real Estate Development Map of Portland, 1889

... page 61

Figure 9. "Portland Residences"

... page 64

Figure 10. "In Portland Gardens"

... page 65

Figure 11. Portland Heights Advertisement, 1909

... page 66

Figure 12. View of Southwest Portland from Portland Heights, c. 1885

... page 66

Figure 13. Group of Residence on Portland Heights c. 1892

... page 67

Figure 14. Aerial Photo of Portland's West Hills (1939)

... page 71

Figure 15. Chinese Leper Known as Wong Suey

.. page 76

Figure 16. Wong Suey’s Home

.. p page 77

Figure 17. Visiting Nurse Association Tubercular Tent

... page 95

Figure 18. TB Ward at the Poor Farm, c. 1907

.. p page 96 


\section{Introduction: Forgotten Bones}

In 2013, major renovations at the Oregon Zoo dug up a surprising discovery: human remains from nine people. Contractors excavating for a major construction project came across bones, as well as some personal items and the outline of a coffin.

Construction came to a halt while the state archeologist was called in. After a detailed site excavation, the archeological team determined the remains belonged to deceased inhabitants of the Multnomah County Poor Farm that used to occupy the site. The remains were then re-interred in a ceremony at an undisclosed location on the Washington Park grounds. ${ }^{1}$

The human remains need not have been surprising: the Poor Farm occupied that site for over forty years, from 1868 to 1911, and contemporaneous newspaper and government records are full of references to the institution. In fact, the 2013 event was not the first time bones were found at the zoo. Reports of bodies and artifacts surfacing date from 2008, the 1970s and the 1950s. By the time the 2013 construction was underway, zoo employees had warned construction crews that such a discovery was possible. But in 1956, when the zoo first moved to this location, no one seems to have considered the possibility. When human remains first turned up, the local newspaper reported: "Records show that the 200 acres now designated for the new zoo was the site of the Multnomah County Poor Farm from 1868 to 1911. Apparently the area was also used as a potter's field — a place for burial of unidentified or unclaimed bodies." ${ }^{2}$ The fact that the people involved in building the new zoo had to search the records to determine

\footnotetext{
${ }^{1}$ Katy Muldoon, "Human Remains of Nine Found During Oregon Zoo Construction Work," Oregonian, September 6, 2013.

2 "Recovery of Bones Reopens State History," Oregonian, June 20, 1956.
} 
where the bones might have come from indicates that the Poor Farm's existence at that location was not widely known forty-some years after its relocation. The relationship of the Poor Farm to the surrounding city was such that it has been forgotten, again and again.

As the records showed, the first Multnomah County Poor Farm opened in the Tualatin Hills, more commonly known as the West Hills, flanking Portland's downtown in 1868. It remained there for over four decades, until, in 1911, the county opened a new facility in the eastern part of the county. The relocation coincided with a time of massive boosterism and deliberate image creation among leading Portlanders. One result of these efforts was a successful campaign to establish Portland as “The Rose City.” Citizens planted thousands of rose plants in preparation for the 1905 Lewis and Clark World's Fair, and the annual festival was officially established in 1907. Ten years later, the International Rose Test Garden opened in Washington Park, near the old Poor Farm land. ${ }^{3}$

In the mind of early-twentieth century boosters, Portland was to be a prosperous, beautiful city, free from the problems of the older eastern cities. ${ }^{4}$ But a crucial component of Portland's positioning itself as a fresh, clean city, with none of the perceived material and moral decay of older urban areas, was exclusion. Promoters built on a legacy of exclusion, including the Oregon Black Exclusion Laws and the Donation Land Claim

\footnotetext{
${ }^{3}$ Erika Weisensee, "Portland Rose Festival," in Oregon Encyclopedia (updated October 6, 2017) https://oregonencyclopedia.org/.

${ }^{4}$ Kimbark MacColl, The Shaping of a City: Business and Politics in Portland, Oregon, 1885 to 1915 (Portland, OR: The Georgian Press, 1976).
} 
Act. ${ }^{5}$ Portland, some boosters felt, would be free from racial strife because this history of exclusionary laws had kept numbers of non-whites low. ${ }^{6}$ It would be free from immigrant-filled tenement slums because local groups would attempt to keep out immigrants they considered less desirable, and architects would largely avoid the tenement model. ${ }^{7}$ And it would be free from visible destitution, because after 1911, the Poor Farm was more than twelve miles outside the city limits.

${ }^{5}$ Darrell Millner, "Blacks in Oregon," in Oregon Encyclopedia (updated September 11, 2017) https://oregonencyclopedia.org/. Oregon's black exclusion laws gave the state a reputation as anti-black that kept Black migration to the territory, and subsequently to the state, low.

Greg Nokes, "Black Exclusion Laws," in Oregon Encyclopedia (September 12, 2017) https://oregonencyclopedia.org/. After the passage of the Fourteenth Amendment in 1866, African Americans were eligible to acquire property through the Homestead Act under federal law. However, Oregon law prohibited African Americans from owning property in the state. Although the federal law technically trumped state law, Oregon's reputation as hostile to Black Americans continued to discourage migration for decades. For those African Americans who did emigrate to Oregon, their success usually depended on their associations and their socioeconomic status on arrival.

${ }^{6}$ David Horowitz, "Social Morality and Personal Revitalization: Oregon's Ku Klux Klan in the 1920s," Oregon Historical Quarterly 90, no. 4 (Winter 1989): 369. Horowitz described the Ku Klux Klan's successful 1920s recruitment efforts in Oregon. The Klan in Oregon focused their efforts on prohibiting land ownership by Japanese farmers and orchard workers and by fighting against supposed dominance of Catholics and foreign-born politicians. Klan activity in Oregon did not focus on Blacks because there were so few Blacks in the state.

${ }^{7}$ Charles Gould, "Portland Italians: 1880-1920" Oregon Historical Quarterly 77, no. 3 (1976): 243-244. Gould described the racial hierarchy promoted by the Oregon Board of Commission. Created in 1871, the Board of Commission tried to recruit immigrants to Oregon, but primarily those of white, northern European descent. In 1913, the successor commission encouraged immigrant groups and societies to advertise Oregon to their kin. Their efforts focused first and foremost on Germans and Scandinavians.

The journalist Ray Stannard Baker in 1903 called Portland's inhabitants (as well as those of other Northwestern cities) "to a singular degree pure American. . these far-Western cities give on the impression of being intensely American: I mean Anglo-Saxon." Ray Stannard Baker, "The Great Northwest," Century Illustrated Monthly Magazine 65 N-AP (1902-1903), https://www.hathitrust.org/.

Ed Teague, "The Apartment Building in Portland: 1900-1930: An Introductory Survey," (lecture, Architectural Heritage Center, Portland, Oregon. November 5, 2016.) "Apartment Building" as a category first appeared in the Portland City Directory in 1904. Although Portland had its share of hotels and lodging houses prior to 1904, it was not until the early twentieth century that apartment living became a respectable option. Even then, many developers in the Portland region, trying to create space between their buildings and the feared tenement slum, built apartment houses that looked like large single-family dwellings. 


\section{Chapter One: The Deserving Poor Revisited}

When Gabriel Roche decided to leave the Multnomah County Poor Farm, he was

74 years old and had been living there for two years. Roche was born around 1826 in St.

Malo, Brittany, France. He came to Portland in 1857 but did not settle. In 1866, he was

working at the North Portland Sawmill and boarding at the New Columbian Hotel. ${ }^{1}$

Roche seems to have traveled around Oregon and California in search of work, but told the local newspaper he returned to Portland in 1898, penniless. He was admitted to the County Poor Farm, where he gave his occupation as "lumberman" and his religion as "Roman Catholic."” The record keeper listed his disease as "destitution."3

Two years later, in December of 1900, Roche left because, in his words, "they have not used me well up there. ${ }^{4}$ He said he could no longer stand the inadequate food and superintendent's poor labor management. The superintendent made him pitch hay alone, a job which Roche believed required at least three men. When he refused to pitch hay any longer, they sent him to work in the woods. As he was taking his dinner with him to his work site, an argument broke out. Roche complained that, "officials refused to give me butter for the bread" and, "the coffee was like dishwash." Further, he said, most of his meals consisted of potatoes, and the skimpy servings of meat were too tough for him to

${ }^{1}$ Portland Directory for 1866 (Portland, OR: S. J. McCormick, 1866): 71.

${ }^{2}$ Admissions Ledger of the Multnomah County Poor Farm and Hospital. Vol I (1900-1904), Multnomah County Archives, Portland, OR; “Because Steak was Tough,” Oregonian, December 18, 1900.

3 Admissions Ledger of the Multnomah County Poor Farm and Hospital. Vol I (1900-1904), Entry Date June 1, 1900. Entry Number 37, Multnomah County Archives, Portland, OR.

Starting in 1900, the institution used bound ledger books with printed template entries that staff filled in by hand. Thus the record-keeper did not write the word "disease," he simply filled in that line. It was not until several years later that the new ledgers changed the wording to say "reason for admission," rather than "disease." Still, the fact that these early record-keepers chose to list conditions such as "destitution," and "malingering" in the disease category might be telling of how they thought of impoverished people.

4 "Because Steak was Tough," Oregonian, December 18, 1900. 
eat due to his bad teeth. ${ }^{5}$ Roche told a reporter for the local newspaper that the Poor Farm's mismanagement had actually cost them money: he claimed the county had hired men to haul lumber and to work on a road near the farm, work he could have done for free. The Poor Farm officials disagreed with Roche's version of events. The institution's ledger listed the reason for discharge as "refused to work." Despite his disdain for the place, Roche lived at the Poor Farm off and on until his death in October 1911, just before the Farm's relocation. ${ }^{7}$

The Oregonian story on Roche from 1900 revealed something of society's attitude toward men like him. The headline: "Because Steak was Tough: After Two Years' Stay Gabriel Roche Leaves the Poor Farm," made light of the man's struggles. The headline, as well as the skeptical tone the reporter took, implied that Roche was an entitled county dependent. He was turned into an amusement at best and a pariah at worst. The insistence that Roche perform work, and that he obey the rules of those providing aid, exemplified American attitudes toward the poor and poor relief.

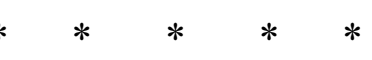

Poor relief in America has, since its inception, relied on dividing the poor into two

\footnotetext{
5 “Because Steak was Tough," Oregonian, December 18, 1900.

${ }^{6}$ Admissions Ledger of the Multnomah County Poor Farm and Hospital. Vols I-II (1900-1908). Multnomah County Archives, Portland, OR; "Because Steak was Tough," Oregonian, December 18, 1900.

${ }^{7}$ Oregon Death Index 1903-1920 reprinted on Ancestry.com; Portland City Directory, Portland, OR: R. L. Polk, 1901. (also 1903, 1907, 1908, 1909) reprinted on Ancestry.com; U.S. City Directories, 1822-1995 reprinted on Ancestry.com. The City Directories for 1907 and 1908 listed Roche as a resident of the County Hospital, while the directories for 1901, 1903, and 1909 listed him as a resident of the Poor Farm.
} 
factions: the deserving and the undeserving. How society, and especially authorities, categorized needy, determined whether they were entitled to aid, either public or private.

Factors such as gender, age, physical and mental ability, marriage status, residence, and

behavior, all contributed to society's recognition of a person as deserving or undeserving.

While poor relief scholars have examined the American impulse to categorize the needy, the effect of the worthy versus unworthy approach to poor relief on the physical landscape of American cities remains under-explored.

Historical scholarship on poor relief flourished during the 1960s and 70s, spurred by the post-World War II social science fascination with cultural explanations for poverty. ${ }^{8}$ Most scholars of the poor during this period took a sweeping approach to

\footnotetext{
${ }^{8}$ Oscar Lewis, Five Families: Mexican Case Studies in the Culture of Poverty (New York: Basic Books, 1959); Michael Harrington, The Other America: Poverty in America (New York: Simon and Schuster, 1962); William Trattner, From Poor Law to Welfare State: A History of Social Welfare in America (New York: The Free Press, 1994); Michael Katz, In the Shadow of the Poorhouse: A Social History of Welfare in America (New York: Basic Books, 1986); Pimpare, Stephen. The New Victorians: Poverty, Politics and Propoganda in Two Gilded Ages (New York: The New Press, 2004).

The academic concept of a "culture of poverty" was introduced in 1959 by anthropologist Oscar Lewis in his book, Five Families: Mexican Case Studies in the Culture of Poverty. Michael Harrington popularized the idea of a culture of poverty in the United States with his 1962 exploration of poverty in America, The Other America, which argued that poverty was entrenched in American society. Just over a decade later, William Trattner's From Poor Law to Welfare State became the most influential synthesis of poor relief in America history. Then in 1983, Michael B. Katz published In the Shadow of the Poorhouse, which remains the definitive history of the legacy of the American poorhouse system. Most social historians of the 1960s-80s acknowledged the following broad eras of American poor relief: 1) The Colonial Era, in which each township was responsible for the care of its poor and applicants for aid were usually boarded in a household, the head of which received a stipend. 2) The move toward institutionalization, which sought to consolidate resources and functioned in growing urban areas where the colonial model was not feasible. This period began in the late eighteenth century and reached its peak in the mid-nineteenth century. 3) The Organized Charity movement, which sought to coordinate the efforts of various charities and thus reduce waste. This movement also saw the rise of so-called "friendly visitors," who were meant to instruct poor people in values that would lift them out of poverty. The Organized Charity movement flourished in the late nineteenth century and arguably was also responsible for an overall reduction in charitable giving. 4) The rise of the welfare state beginning in the Progressive Era and epitomized by the New Deal. At the time many of these historians were writing, the de-institutionalization movement, 1990s welfare reform, and other reductions in safety net programs had not yet occurred. More recent historians, however, such as Stephen Pimpare, do address these developments of the late twentieth and early twenty-first centuries. In The New Victorians, Pimpare drew parallels between the wealth inequality gap of the Gilded Age and that of the 1990s and 2000s.
} 
poverty and relief efforts. Even while acknowledging that myriad variations at local, state, and regional levels were always fundamental to America's poor relief practices, they nevertheless highlighted major trends in ideology around, and implementation of, poor relief measures.

In recent years, historians have returned to poverty and poor relief scholarship, often taking a case study approach. Both the synthesis approach and the narrower studies of individual cities help historians understand Americans' relationship to poverty and efforts at relief. My research takes a case study approach while incorporating broader historical trends outlined by synthesis scholars of poor relief. ${ }^{9}$ In addition, I will draw on the scholarship of urbanists and environmental historians to examine the relationship between poor relief and land use. By tracking the development of a 202-acre plot of land in Multnomah County, Oregon, it is possible to see how the American impulse to distinguish deserving from underserving poor played out, quite literally, on the ground.

\section{Early Multnomah County Poor Relief}

Poor relief in the Oregon during the territorial period initially followed the old colonial practice of boarding the indigent in private homes, but within a few years, Multnomah County leaders decided to create an institution to house the poor. Journals of the Board of County Commissioners for Multnomah County showed that in the 1850s, the Court generally administered relief in piecemeal fashion. ${ }^{10}$ Individuals would petition

\footnotetext{
${ }^{9}$ For example, Katz, Trattner, and in the twenty-first century, Stephen Pimpare.

${ }^{10}$ Sharon Nesbit and Tim Hills. Vintage Edgefield: A History of the Multnomah County Poor Farm and McMenamins Edgefield (Portland, OR: McMenamins, 1995): 3. Five years prior to statehood, in 1854, the Oregon territorial legislature put counties in charge of caring for the destitute.
} 
the Court for aid, and their petitions could be granted or denied. When granted, aid could take the form of a one-time payment for food or rent, a fuel subsidy, or a recurring stipend, which was usually reserved for widowed or significantly disabled applicants. In some cases, especially those involving children, the court might find a private household in which to board them. In exchange for providing room and board to the indigent person or children, a private citizen received a stipend from the county. ${ }^{11}$ On April 3, 1855, H. W. Clayton presented a bill for boarding Henry Marshall, "an insane man," for twentythree days at the cost of one dollar per day. After hearing from another man that Marshall had been a resident of the county for at least twelve months, the county commissioners ordered that Clayton be paid fifteen dollars. ${ }^{12}$ On July 5 of the same year, Hiram Smith presented a bill for boarding Mrs. Kimberly, another "insane pauper," and providing her with clothes. The commissioners rejected this claim, saying it was not their

${ }^{11}$ A vast body of literature exists relating to the practice of boarding the poor. This practice in America originated in colonial times, when the primary form of aid was so-called out-relief, that is, aid given outside of an institution. Out-relief took three general forms: boarding with a family, in-kind assistance, or auctioning off of a needy person, for labor, to a wealthier citizen. In the Northern colonies, boarding of an indigent person with another household was the predominant method. For an examination of such boarding see: Geoffrey Guest, "The Boarding of the Dependent Poor in Colonial America," Social Service Review 63 no. 1 (1989): 92-112, http://www.jstor.org.proxy.lib.pdx.edu/stable/30012002. Guest argues that the family unit was the primary vehicle of relief during this period.

For more examination of colonial out-relief, also see Ruth Wallis Herndon, "'Who Died an Expence to This Town:' Poor Relief in Eighteenth-Century Rhode Island," In Down and Out in Early America, edited by Billy G. Smith, 135-162 (University Park, Pennsylvania: Pennsylvania State University Press, 2004). Herndon traced the ill fortune of a woman who sought relief in Rhode Island during the colonial era. She demonstrated the process through which a person acquired aid, or was rejected from aid, during this era. Herndon also described "warning out," a practice whereby town leaders determined that an applicant did not belong to their town. This meant rejecting the applicant's plea for aid, prohibiting them from begging in town, and barring them from applying for relief in the future. Also see Trattner's second chapter, "Colonial America" in From Poor Law to Welfare State. Trattner charged that while colonial poor relief was astoundingly generous to those for whom the community took responsibility, the practice completely neglected those poor whom the community rejected.

${ }^{12}$ Journal of the Board of County Commissioners of Multnomah County, entry for April 3, 1855, Multnomah County Archives, Portland, OR. 
jurisdiction. ${ }^{13}$ This case-by-case approach, alongside aid from churches, was typical of poor relief efforts in the years leading up to, and just after, Oregon's gaining statehood in 1859.

In 1862, only ten years after Portland was founded, Multnomah County dabbled in institutionalizing the poor, when county leaders contracted out care of some indigent residents to James C. Hawthorne and Abram Loryea, who ran the Oregon Hospital for the Insane. In order to be admitted to the hospital, applicants needed a written order from the county judge. ${ }^{14}$ Others continued to board in the homes of private citizens, and out-relief continued too. In 1867, the county furnished Charles Frizette with a wooden leg for 161 dollars so he could earn a living, "it appearing to the court that said Frizettte will be able to do so." ${ }^{.15}$ Here again is the American belief that people should work to support themselves whenever possible. Further, Hawthorne's hospital was expensive, and leaders soon sought a cheaper method of administering poor relief. At the same time, Portland's population surged. ${ }^{16}$ Feeling that the need was too large to determine petitions on a caseby-case basis, the county purchased land for a poor farm in 1868 from the land claim of

${ }^{13}$ Journal of the Board of County Commissioners of Multnomah County, entry for July 5, 1855, Multnomah County Archives, Portland, OR. The commissioners may have determined that Mrs. Kimberly was not a resident of Multnomah County, and therefore not entitled to aid. It is unclear how she came to be living with Mr. Smith.

${ }^{14}$ Journal of the Board of County Commissioners of Multnomah County, entry for February 10, 1865, Multnomah County Archives, Portland, OR. The terms of the contract also seemed to imply that the court could compel someone to go the hospital for a set period of time. In 1862, the Oregon Hospital for the Insane ran multiple advertisements in The Oregonian, claiming that all indigents would be paid for at state expense. It is unclear whether this applied to people of sound mind and body who were impoverished, or only to those who were deemed insane, lame, or idiotic. Meanwhile, throughout the 1860s, the Journal of the Board of County Commissioners continued to record payments made to individual citizens for boarding paupers.

${ }^{15}$ Journal of the Board of County Commissioners of Multnomah County, entry for June 30, 1867, Multnomah County Archives, Portland, OR.

${ }^{16}$ Between 1860 and 1870 , the population of Portland and the surrounding area grew from 2,874 to 8,293 . In the same period, the population of Multnomah County grew from 4,150 to 11,510. Nesbit, Vintage Edgefield 3. 
early Portland investor Stephen Coffin. The county bought the 202 acres on Canyon Road for $\$ 4,000 .^{17}$

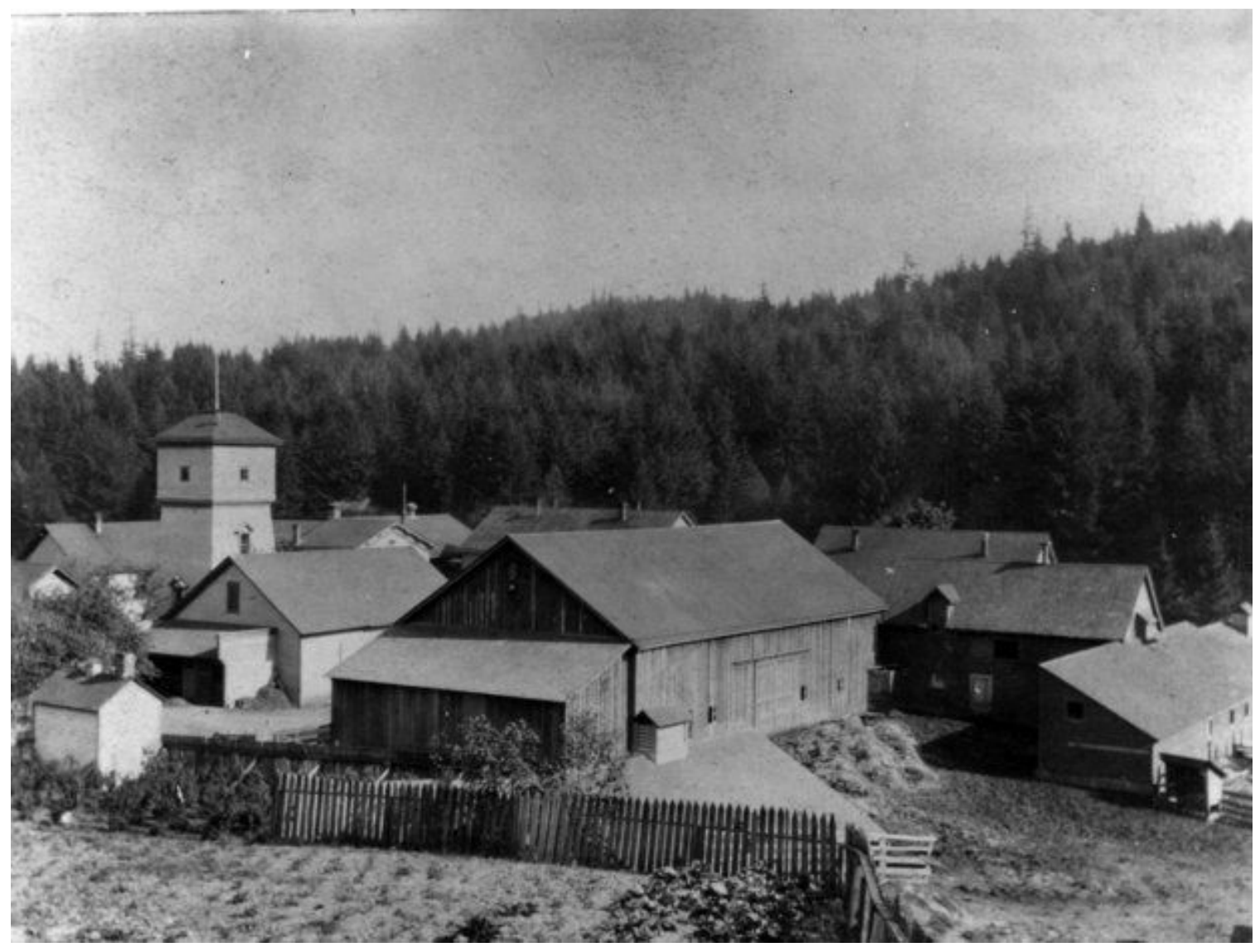

Figure 1. Multnomah County Poor Farm on Canyon Road, Rear View, c. 1907 The first Multnomah County Poor Farm on Canyon Road. The author believes this photo shows the "back" of the Farm, with Canyon Road located between the outcropping of buildings and the forested area. [Courtesy of Oregon Historical Society, neg 0121251]

In establishing a poor farm, the county commissioners were following the national movement toward institutionalization. The alternative, out-relief, referred to aid administered outside of an institutional setting, including everything from firewood and grocery allowances to boarding and residence with a fellow town member, and, in rare

${ }^{17}$ Journal of the Board of County Commissioners of Multnomah County, entry for June 4, 1868. Multnomah County Archives, Portland, OR. 
cases, cash assistance. ${ }^{18}$ In older, more populous cities, the movement toward institutionalization of criminals, the insane, the sick, and the indigent coincided with the rise of the market economy in the $1820 \mathrm{~s}-1840 \mathrm{~s} .{ }^{19}$ But in many cases, handouts of food or cash persisted alongside institutional aid. With the rise of the organized charity movement in the late nineteenth century, out-relief increasingly came under attack from reformers who believed that poor people needed to be removed from their patterns and routines. Reformers of the organized charity movement generally favored less aid of monetary value and more instruction in personal and spiritual values. They believed that cultivating the proper lifestyle would help uplift impoverished people from their fallen, undeserving state. Providing these people with subsistence would only encourage them to continue living a lifestyle devoid of virtue. In order to make themselves worthy recipients of aid, poor people had to be willing to change — and reformers believed this change was best affected in an institutional setting. Partially through the efforts of the organized charity movement, during the late nineteenth century, government at every level moved toward indoor, institutional, relief only. ${ }^{20}$

Supporters of the new Multnomah County Poor Farm cheered the good it would do for the paupers - and the county's pocketbooks. A letter to the editor of The

\footnotetext{
${ }^{18}$ For an in-depth explanation of the movement to end out-relief in cities, see Michael B. Katz, In the Shadow of the Poor House (1986).

${ }^{19}$ Mimi Abramovitz, Regulating the Lives of Women: Social Welfare and Policy from Colonial Times to the Present (Boston: South End Press, 1988): 144-150. Abramovitz attributed the reform of colonial poor laws to a new explanation of poverty that accompanied the market economy: poverty was no longer an accepted, perhaps even divinely ordained, part of the natural order but the result of individuals' failure to discipline their lives and their labor.

${ }^{20}$ For discussions of the efforts to abolish out-relief, see Stephen Pimpare, The New Victorians (2004), Michael B. Katz, In the Shadow of the Poorhouse (1986) and William Trattner, From Poor Law to Welfare State (1994). For a structural, Marxist-leaning discussion of the move toward institutions as instruments of reform, see Mimi Abramovitz, Regulating the Lives of Women (1984).
} 
Oregonian wrote in 1868 of the proposed changes to the county's poor relief: "It is believed that under a different system the pauper expenses of the county can be greatly decreased. It is certain that the present system encourages unworthy persons to make themselves a county charge." Furthermore, the letter continued, "persons who are ruined by dissipation and debauchery, who have lost all honorable ambition" had easily gained admission to the Hawthorne hospital, because the proprietors were paid per patient and therefore incentivized to maintain a lax admissions policy. ${ }^{21}$ The new farm, it seemed, would apply a more rigorous standard to parsing the deserving from the undeserving.

Some locals also believed the country setting would benefit the paupers because physical work in the outdoors would instill the virtue needed for these unfortunates to pull themselves out of poverty. Government records and newspaper editorials showed no coherent plan for teaching the Poor Farm residents skills; rather, the system rested on the vague idea that discipline, cleanliness, and sobriety, as enforced at the institution, would allow the healthy residents to make a go of it on the outside. Further, access to fresh air would help the sick. The farm was, from its inception, a de facto hospital, and many descriptions of the facility praised the invigorating nature of the country air.

Perhaps even more compelling than the potential benefits to the future residents was the price: the commissioners paid about twenty dollars per acre for the Poor Farm land. By comparison, three years later, the city of Portland paid eight hundred dollars per

21 "Maintenance of the Poor," Oregonian, June 27, 1868. Bitter political party rivalries also played a role in the conversation around creating a poor farm. Dr. Hawthorne was affiliated with the Democratic Party, which, in 1868, was still reeling from its association with the Confederacy during the Civil War. The Oregonian and its publisher, Thomas Dryer, were staunchly Republican. For more information, see "The Oregonian" entry by Harry Stein in the Oregon Encyclopedia. Harry Stein, "The Oregonian," in Oregon Encyclopedia (updated October 2, 2017) https://oregonencyclopedia.org/. 
acre for the plot just west of the city that would become City Park. ${ }^{22}$ Furthermore, while the Poor Farm land boasted a view of mountains and river, the dearth of accessible roads rendered much of the West Hills marginal land, not ready for development. The low cost, high-altitude, and considerable distance from the city made the location a reasonable one in the eyes of the county commissioners.

People gained admission to the Poor Farm through a variety of means. Sometimes residents in need directly asked the county for admission to the Poor Farm, sometimes they applied for another form of aid but were offered only the Poor Farm, and sometimes they were sent there to get them off the streets. The latter was especially true for those charged with nonviolent offenses, such as vagrancy. While the number of residents climbed over the decades from 1868 to 1911 , the ratio of men to women always remained high. One possible reason for the gender imbalance is that the county commissioners liked to keep children out of the farm if possible, and they were more likely to grant outrelief to widows and mothers than to unattached men. At times, however, infants and children were admitted with their mothers.

In the early years, reports from the Hillside Poor Farm were positive. ${ }^{23}$ In 1873 , staff from The Oregonian visited the farm alongside the county commissioners. The

${ }^{22}$ E. Kimbark MacColl, The Shaping of a City: Business and Politics in Portland, Oregon, 18851915 (Portland, OR: printed by the author, 1976).

${ }^{23}$ The Poor Farm's official title was the Multnomah County Poor Farm, both at the original location and at the second location in Troutdale. Both locations also developed unofficial names. The original location in the West Hills came to be known as the Hillside Farm, but it is unclear whether this happened during the farm's existence or after. The second location came to be known as Edgefield, though this name was not used during the farm's lifetime; rather, Edgefield was the name of a nursing home that occupied the space after the farm closed. The McMenamins brothers kept the name Edgefield when they purchased the property and turned it into a restaurant, brewery, and concert venue in 1990. For clarity, and despite the anachronism, this paper will at times use the terms Hillside Farm and Edgefield Farm to refer to the original West Hills location and the later Troutdale location respectively. 
newspaper described the cheery surroundings and exemplary management. "One glance at the neat and handsome building with its fresh coat of paint, as it stands on an elevated point of land, surrounded by green gardens and a fruitful orchard, at once invites the eye and pleases the fancy," the author wrote. The article continued, "These agreeably pleasant surroundings are well calculated to instantly dispel all ideas of gloom, want, disease and sadness, which even the name of the place would cause one to naturally associate in the mind." 24 The simple name, "poor farm," conjured images of wretchedness for this observer.

Reports of the grand jury from the 1870s reflected the hope that the Poor Farm would become self-supporting. ${ }^{25}$ The juries generally praised the superintendent's management and wrote favorably of the sale of farm produce. A notable exception to the positive reports came in March 1876, when the grand jury stated that the land was unsuitable for farming. Referring to the tree-covered hills on the property, the report said the expense of clearing the land so as to make it "only a tolerable farm" would be far too high, and further, the property was "altogether too burdensome and expensive for the county." ${ }^{26}$ The grand jury may have been right, as the farm never became self-supporting. This report was one of the earliest recorded complaints about the Poor Farm, but it would not be the last.

\footnotetext{
24 “The County Poor Farm," Oregonian, July 21, 1873.

${ }^{25}$ The grand jury in this context was not investigating a criminal case. Rather, the grand jury was a regularly-convened group of citizens whose responsibility it was to visit the public institutions, including the Poor Farm, the jail, orphanages, etc., and ensure they were being run properly.

26 "Report of the Grand Jury," Oregonian, March 9, 1876.
} 


\section{Increasing Scrutiny: the 1870s-1890s}

Beginning in the late nineteenth century, the picture at the county farm looked less rosy. The Multnomah County Poor Farm seemed to work impressively well for its first two decades and subsequently began to attract criticism. ${ }^{27}$ During the 1880 s and 1890s, The Oregonian often referred to the grounds as crowded, particularly during winter months. At the same time, for much of the institution's existence, the buildings only occupied a portion of the county land. Rather than relocate the farm, county officials continued to build and expand on the same plot. But once the luster became tarnished, and especially as the ranks of the poor continued to swell, Portlanders questioned the utility of the farm as an antidote to pauperism.

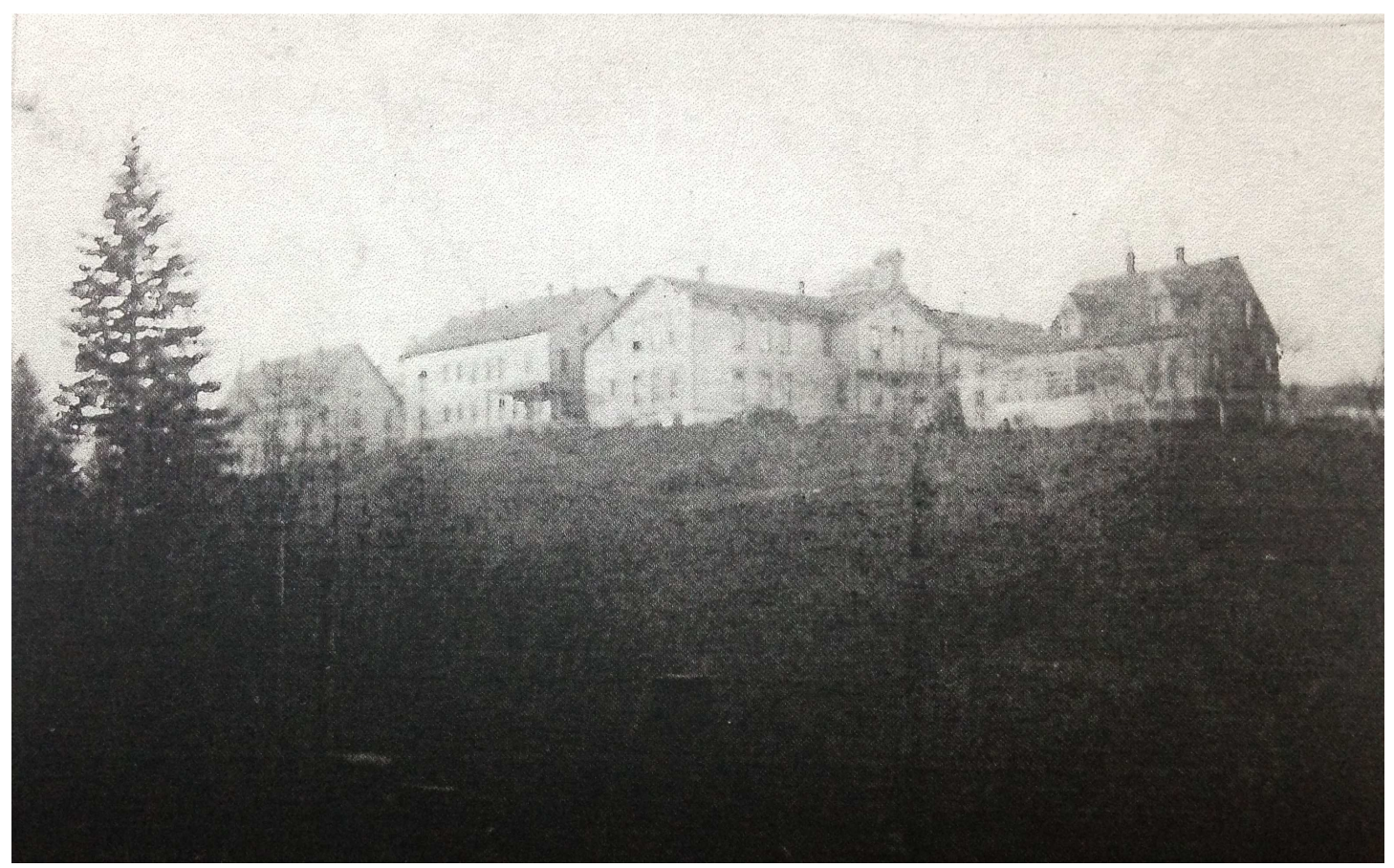

27 The Multnomah County Poor Farm's operations followed an arc laid out by Michael Katz. According to Katz's analysis, most cities that built poorhouses reported a decrease in pauperism at first, but after two or three decades, the workhouses and poor farms became less productive. Most of Katz's examples of this phenomenon were east of the Mississippi and began several decades prior to the establishment of the Multnomah County Poor Farm. Nevertheless, the similar arc implies that the structure of the system, rather than shared geography or time period, dictated the poor farm's development. 
Figure 2 (previous page). Multnomah County Poor Farm on Canyon Road, Front View. This image is c. 1907. Comparison to a 1908-1909 Sanborn map indicates the buildings may be, from left to right, the poor house, men's ward of hospital, main hospital building, and superintendent's house. [Courtesy of Oregon Historical Society]

As early as 1877 , The Oregonian began publishing editorials and letters to the editor from citizens who felt the Poor Farm land could be put to better use. These articles always reflected the opinion, sometimes implied and sometimes explicitly stated, that the 200-acre parcel was "too good" for public welfare. They also usually expressed concern for the inmates, and the idea that their needs would be better served elsewhere. In a bombastic letter to the editor in 1877 , one citizen insisted that numerous complaints against the Poor Farm warranted a closer investigation and suggested in addition that the land be sold. "Now, in the name of these forsaken inmates of the Poor Farm, I raise my voice in their defense," wrote the anonymous PUBLIC WELFARE. ${ }^{28}$ The solution, according to PUBLIC WELFARE, would be to contract care of the poor out to the lowest bidder (which was actually the status quo prior to the farm's creation) and use the land for something else.

Throughout the 1880s, occupancy at the Poor Farm crept upward, though the total number remained relatively low throughout the decade. In November 1879 , the farm reported twenty-two inmates. During the month, 14 more were admitted and ten discharged, bringing the total count to 26 , of whom five were born in China, one in Prussia, eight in other American states, and one each in England, Scotland, and Australia. The following year, the county enlarged the main building, increasing capacity. ${ }^{29}$ Of the

28 "The County Poor Farm," letter to the editor, Oregonian, March 12, 1877.

29 "City," Oregonian, August 18, 1880. 
new construction, an 1882 grand jury noted: "A new house, roomy and commodious, has been constructed, in which a number of families can be accommodated at less cost to the county than on the present plan of paying rents to poor families in the city. But so far no family has accepted the offer, preferring the city and want to plenty and comfort at the poor farm." 30 The remarks about paying rent to poor families indicated that out-relief was still taking place and that most families preferred it to institutionalization.

A turning point in the Poor Farm's development came in 1885, as squabbles broke out over treatment of the poor. The Oregonian had long supported Robert Cleghorn, who served as superintendent of the farm from 1870 to 1885 . In Cleghorn's final year, the newspaper ran a report detailing the expenses of the farm and implying that the superintendent did not spend enough money per pauper. Cleghorn, it claimed, made over $\$ 1,000$ per year, but the output for each pauper was less than four cents per day. The report lent credence to claims by inmates that good food was scarce. ${ }^{31}$ Throughout the year, the grand juries, newspaper reporters, and county commissioners put forth conflicting accounts of the farm's state of affairs. Finally, in December 1885, The Oregonian confirmed the grand jury's accusations of inadequate and neglectful conditions. The paper quoted the grand jury report: "We find at the poor farm sixteen inmates, of which three are sick. These sick people are confined in an upstairs portion of the old building. A part that is not suitable for a sick person from its structure and lack of warmth, and from the fact that the building is so constructed that there are large cracks through which the wind blows and exposes the patients unnecessarily to drafts of cold

\footnotetext{
30 Ibid.

31 "Cost of Keeping the Poor," Oregonian, October 8, 1885, page 3.
} 
air." 32 In response to the uproar, the county expanded and updated the buildings.

Since its early years, the Multnomah County Poor Farm functioned as both a boarding house and hospital. The attempt to serve the sick, the poor, and the aged in the same institution was the rule for American poor relief, rather than the exception. One of the fundamental contradictions in the history of American poor relief is the effort to treat both the deserving and undeserving poor by the same means. Across the country, poor houses and poor farms were meant to be places of refuge for those deemed worthy of society's help, such as amputees and the elderly. At the same time, officials attempted to construct infrastructures that would be unappealing enough to deter the "unworthy," such as able-bodied men, scammers, and the intemperate, from taking advantage of the government's generosity.

These competing impulses: to deter and reward, to rehabilitate and to confine, were so incompatible that poorhouses and poor farms failed to accomplish either objective. ${ }^{33}$ In Multnomah County, one such contradiction was that the poor were supposed to labor on the farm for their room and board, but most of the residents were too sick or too old to perform heavy physical labor. An investigation of the superintendents' reports over the decades shows that the farm often hired laborers because there were not enough able-bodied adults to work the land. Ironically, an ablebodied adult, especially a man, would not be considered a worthy recipient of public aid.

32 "Grand Jury Report: Poor Farm Management at Last is Condemned," Oregonian, December 10, 1885 , page 2 .

${ }^{33}$ Michael Katz wrote extensively about the incompatible impulses embedded in American poor relief. Katz argued in both In the Shadow of the Poorhouse (1986) and The Undeserving Poor (1989), that the inability of an institution to serve as both a place of refuge and a deterrent made the poor house an ineffective system. 
When Cleghorn's successor, Superintendent McBride, was criticized in 1893 for not requiring his inmates to perform more labor, he responded that his population was unfit to do it. He argued that the farm housed fifty old men, ranging from sixty to ninety years, and that the young men housed there were unable to work due to disability or illness. His rebuttal was published in The Oregonian, where he wrote that the County Court granted admission to the farm "only to those who are not able to work, and to the old and destitute." ${ }^{34}$ He continued: "Because a man is disabled so that he cannot work is no reason that he should be called a filthy sluggard." Superintendent McBride's words reflected the belief that people who cannot perform work, because of their age or because they are "broken down with all sorts of ailments," are deserving of relief and goodwill. ${ }^{35}$ The farm could not retain an adequate supply of labor, McBride argued, because the long-term residents were disabled and as for the short-timers, as soon as they were healthy enough to work they would "get up and skip out." 36 The few that remained and were capable of the heavy labor necessary to run a farm and maintain a household could not be expected to do the laboring and cooking required to feed eighty or ninety people, McBride persisted. The situation would only worsen, as the panic of 1893 and subsequent depression led to decreased employment for thousands of Oregon laborers. ${ }^{37}$

Even as the population of the Poor Farm continued to increase, reports of the grand jury remained generally positive throughout the institution's tenure in the West

34 “The Poor Farm. Superintendent McBride Replies to the Grand Jury,” Oregonian, August 8, 1893.

35 Ibid.

${ }^{36}$ Ibid.

${ }^{37}$ Michael Munk, "Coxey’s Army," in Oregon Encyclopedia, (updated September 20, 2017) https://oregonencyclopedia.org/ 
Hills. ${ }^{38}$ In 1895 , with the country still in a depression, a charity report described the farm as "pleasantly located" on Canyon Road in a "healthful" setting. The report also noted that of the approximately one hundred residents of the farm and hospital, all "received good care and attention.” The report praised the economy with which the residents were kept, lauded Portlanders' generosity, and bemoaned the "indiscriminate begging" that they believed arrived with the transcontinental railroad. ${ }^{39}$ The charity approved of the care administered at the Poor Farm, but did not approve of all those who received it.

Portlanders welcomed the national rail connection and the increased business and economic opportunities the improved infrastructure brought, but they also complained that the increasing population bred pauperism. An article from 1899 lamented that "as the country fills up with people, the pauper element increases." The Multnomah County Poor Farm at that time held 54 inmates -47 men and seven women. The use of the term "inmates" to refer to the inhabitants connotes a criminality regarding their situations as people who could not support themselves. All seven of the women had been "deserted by profligate husbands, leaving them penniless and in broken health." The superintendent said every person in his charge is "afflicted with one disease or another" and mostly "they belong to the uneducated class." The article continued: "in almost all instances their misfortune may be traced to the use of liquor." ${ }^{40}$ It is unclear whether this commentary on the poor farm population came from the superintendent or the journalist editorializing, though it seems to be the latter. The article belied the author's belief that pauperism was

\footnotetext{
${ }^{38}$ Reports of the grand jury relating to the second Poor Farm location are beyond the scope of this thesis.

39 “Generous Portland,” Oregonian, January 1, 1895.

40 "Multnomah's Sick Paupers: Superintendent McBride Says It is as Orderly as a Well Regulated Household," Oregonian, December 7.
} 
caused by both a societal and personal failing: overpopulation and alcohol use.

\section{The Floating Men Scare}

The anxiety that late-nineteenth-century Portlanders expressed about the increasing population centered on the transient male laborer. From the 1880s through the 1920s, Portland hosted a large pool of uneducated migratory laborers, mostly young men, seeking employment in logging and agriculture. In the closing decades of the nineteenth century, development of railroad networks around the state connected Portland to the coastal timber forests, the rich orchards of the Columbia River Gorge, and the wheat fields of central and eastern Oregon. The state's booming agriculture stirred visions of greatness. But for the thousands of men who supplied the labor needed to harvest the natural resources, the end of the season came abruptly. The Poor Farm population swelled in winter as the seasonal employment dried up. ${ }^{41}$

During the 1890s, the public conversation around poor relief revealed increasing anxiety about the "floating men" and scammers. The conservative-leaning Oregonian frequently featured articles questioning the worthiness of applicants for aid. A January 1890 article illustrated this trend. The author of this humorous, but critical, piece, described a young "stout and able-bodied" man who came before the county court asking for admission to the Poor Farm. When the judge asked him what had happened to the

${ }^{41}$ For a discussion of Portland's floating labor population, see Marin Elizabeth Aurand, "The Floating Men: Portland and the Hobo Menace, 1890-1915" (master's thesis, Portland State University, 2016), http://pdxscholar.library.pdx.edu/open_access_etds/2400/. Aurand writes that "the growth of transient labor created a narrative antithesis within the city. This temporary labor force was necessary to sustain Portland's wealth but operated outside of the Portland mythology." Aurand, "The Floating Men," (2015): 3. 
money he saved from working, he replied that he had two little brothers to support, and that his father had been dead for seventeen years. At that point, the judge became even more skeptical, wondering just how "little" his brothers could be if their father had been dead so long (no one seems to have considered that they may have been half-brothers or step-brothers). The article mockingly described the young man's sick, coughing act ("it was forced") and scoffed that the truth was, "he wanted to get out of the snow." ${ }^{42}$ Despite questioning the applicant's motives and story, the judge did allow him admission to the Poor Farm. The author did not go so far as to say the young man should be denied housing, but the story's purpose was to discredit the applicant, relegating him to the ranks of the undeserving. In such cases, meager aid might be offered—with admonishment.

The same article, in describing the winter uptick in applications for assistance at the county board of charity office, cautioned: "While many of the applicants are deserving of sympathy and assistance, there are a great many more who are not." The paper went on to describe the deceit these undeserving poor foisted on honest citizens: they were "professional dead-beats and imposters, who have reduced the art of piousfaced beggary, to a science. They have studied effect in manners, posture, voice, etc. until they have become expert actors in their profession." ${ }^{43}$ The newspaper writers, representing conservative Portland voices, showed little sympathy to those they considered undeserving. It seemed the railroad brought in not only wheat and fruits, but also scammers and tramps.

A letter to the editor of that same year suggested the city could save money by

42 “Under Cross Fire,” Oregonian, January 19, 1890, page 7.

43 Ibid. 
setting the paupers to work and rounding up men from the streets. The anonymous author wrote: "The superintendent of streets and sprinklers should keep the streets clean, do away with the men, do away with the poor farm, and make the paupers look after the fire department." 44 The city at the time had not developed an effective garbage management system, and newspaper articles and reports from the health authorities frequently mentioned the refuse problem. The author of this letter simultaneously nodded to the men on the streets, some of whom were probably employed inconsistently and others permanently unemployed, and the trash issue, implying that the men were, in fact, part of the refuse problem.

For those Portlanders aligned with the politics of The Oregonian, lack of employment was not a legitimate cause of poverty. Those who were seasonally employed could have managed their resources better, they believed. Further, these young laborers often lived in and frequented the rowdy, racy waterfront and North End districts—known areas of vice. ${ }^{45}$ If these men squandered their summer earnings on liquor and prostitutes, why should the rest of society support them when the money ran out and the cold set in? This kind of thinking, coupled with widespread fixation on tramps and vagabonds, rendered the Poor Farm vulnerable to criticism by those who felt it was catering to the undeserving poor.

44 "Reduce the Expenses of this Village," letter to editor, Oregonian, August 1, 1890.

45 Aurand, "The Floating Men," (2015): 33-26. Aurand describes the North End district, which roughly corresponds to today's Old Town neighborhood, as the populated primarily by young, male, unskilled laborers, but one of the most racially diverse areas of the city. The area offered cheap lodging houses and employment postings. It also attracted businesses and organizations whose main focus was young men, such as bars, brothels, and reform agencies like the Salvation Army. 


\section{The Breaking Point: 1900 Onward}

The first decade of the twentieth century ushered in the most tumultuous portion of the Hillside Poor Farm's history. Turnover among the staff was high and conflict between the superintendent and the head nurse resulted in the latter's resignation in 1904. That same year, turmoil broke out as staff members and inmates accused Superintendent J.E. Courtney of mismanagement and abuse. This drama came to a head when Courtney reportedly burst into County Judge Lionel Webster's office and engaged in a heated altercation. The argument involved two elderly residents of the Poor Farm who had walked into town and gotten drunk. The judge had allowed the men to return to the farm, and Courtney reportedly wanted to shut them out for a few days as a punishment. ${ }^{46}$ Courtney was asked to resign, but he refused to go quietly.

In an even more scandalous turn of events, The Oregon Journal broke the news that Courtney had been trafficking in human bodies during his superintendency. He reportedly objected to a postmortem examination of two inmates who died at the Poor Farm, thus tipping off officials that something was amiss. After interviewing Poor Farm janitors and porters, who were responsible for moving and disposing of bodies, the The Oregon Journal reported that Courtney had been selling bodies to the University of Oregon Medical School for ten dollars each, then charging the school $\$ 2.50$ to bury the remains back at the Poor Farm. In addition, Courtney had an arrangement with the city whereby he received ten dollars for disposing of unclaimed corpses of people who died in the city. By selling these bodies to the medical college and then burying the remains at the Poor Farm, he could make as much as $\$ 22.50$ per body, the The Oregon Journal

46 "Courtney Meets Severe Rebuff," Oregon Journal, August 18, 1904. 
stated ${ }^{47}$ The beleaguered superintendent insisted that his operations were above board. The body-selling story followed several months of reporting on alleged abuses at the farm, and the county court asking for Courtney's resignation. Shortly after Courtney refused to resign, the The Oregon Journal ran the story, in which the newspaper also reported that the superintendent had been padding his monthly expense reports by inflating the number of inmates at the farm. Whether forces conspired to oust Courtney or the body selling really was the final injury in a long string of abuses, he was gone and new superintendent D. D. Jackson had taken over by 1905.

Despite the previous years' tumult, the Poor Farm population continued to increase. In 1907, The Oregonian bragged that although the "pauper colony" population had swelled to double the previous record, the paupers were "better conditioned than half the dwellers of the big cities of the world." ${ }^{\prime 48}$ Furthermore, an inspection of the county farm was "more like a stroll through an Iowa farm than an examination of a public institution for the homeless poor." The author described the farm as a bucolic respite and the hospital wing as immaculate and "in almost military order." Perhaps most striking of all, the author wrote that the tuberculosis ward was safely separated from the rest of the farm and that there "penniless victims of the great scourge receive treatment equal to that which money can buy in any place in the world." The seventy patients of the tuberculosis ward reportedly enjoyed separate, open air sleeping compartments and, as frequently as needed, fresh eggs, milk, vegetables and chicken, all raised on the farm. ${ }^{49}$ Only two days later, the paper ran an article claiming the paupers enjoyed too many privileges for people

47 "Sells Poor Farm Dead," Oregon Journal, October 19, 1904.

${ }^{48}$ Thomas Chauncy, "Pauper Colony Reaches Record," Oregonian, August 12, 1907.

${ }^{49}$ Ibid. 
living off the public dole. Though hard luck may have been the case in years past, lush conditions at the Poor Farm now created a "premium on pauperism," it said. ${ }^{50}$ Taken together, these articles seem to argue that the county was spending too much money on the Poor Farm, and that most of the residents were undeserving of such aid.

A year after this glowing, if snide, report of Poor Farm conditions, the county commissioners began developing plans for a new Poor Farm with modern buildings on the East Side of the river. ${ }^{51}$ If the Hillside Poor Farm was a model community, why did the commissioners feel the need to relocate it? By 1909, The Oregonian editors, as well as residents of the unincorporated Sylvan area, were agitating for the farm's removal. In March of that year, the newspaper ran an editorial entitled, "Move the Poor Farm," in which the author argued the Canyon Road location was too large for a Poor Farm (a point that contradicts the 1907 reports of overcrowding) and that the land would be better suited for a park..$^{52}$ The farm's proximity to the city was troublesome, according to the editorial author, because many men had landed in the poor farm as a result of dissipation, and the ability to walk to downtown saloons was too great a temptation for them.

Furthermore, property-owners of Western Multnomah County, especially in the Sylvan area, saw the Poor Farm as holding them back from westward expansion and economic growth. At a meeting of Sylvan property owners, Mr. Harvey O'Bryan, a member of the committee appointed to investigate the United Railways' intentions in Western Multnomah County, reportedly said: "We property-owners west of the city have other plans in mind for upbuilding our section. We want the county to move the Poor

\footnotetext{
50 “Our Model Poor Farm," Oregonian, August 14, 1907.

51 "Poor Farm on East Side," Oregonian, July 9, 1908.

52 "Move the Poor Farm," Oregonian, March 19, 1909.
} 
Farm away from the Canyon Road as soon as practicable and we want the City of Portland to keep away from that road with its pesthouse. ${ }^{, 53}$ Even as grand jury reports on the Poor Farm remained positive, neighbors, and the interests represented by The Oregonian, were eager to get the institution out of the West Hills. ${ }^{54}$

\section{Why Did the Poor Farm Move? The Historical Record}

Very little has been written about the original Multnomah County Poor Farm, and the existing scholarship does not address the question of why the Poor Farm was moved. Most references to the Hillside Poor Farm's relocation rely on the work of two local historians who co-authored a short history of the second Poor Farm location. Their work states, correctly, that investigations of the Poor Farm by charitable organizations in 1910 put pressure on the county to speed up construction of the new Edgefield Poor Farm. The infamous report came from the Visiting Nurse Association (VNA), a charitable organization comprised of trained nurses and wealthy philanthropic women who provided free healthcare to the needy. ${ }^{55}$ In particular, the local VNA focused on treatment of tuberculosis patients. When the VNA investigated the tuberculosis ward at the Poor Farm

53 "Want Road Built and Promises Kept," Oregonian, April 13, 1909.

${ }^{54}$ It is worth noting that Oregonian publisher Henry Pittock purchased the land for his West Hills mansion in 1909. I do not pretend to know what Mr. Pittock's personal opinion of the Poor Farm or its inhabitants was (though based on the paper's editorials I would argue it was a skeptical, fiscally conservative one) but Mr. Pittock's land was directly across the Burnside Street Canyon from the southern, unused portion of the Poor Farm land. Certainly it is plausible that he would have preferred a park or a high-end residential area that would be a boon to his property, rather than a social welfare institution, for a neighbor.

${ }^{55}$ The Visiting Nurse Association began in New York in the 1880s as a charitable organization that sent nurses to care for the sick in their homes. VNAs sprung up all over the country, some of which were connected to each other and some of which operated independently. Today, VNAs vary greatly from association to association, with some being non-profit organizations and others for-profit. The Portland VNA was a non-profit organization, whose board members consisted of Portland society's high-ranking women. They employed nurses and eventually worked in coordination with other service agencies to provide care for indigent sick, with a special focus on tuberculosis. 
in 1910, the women reported that conditions at the farm were "deplorable." 56 The visit prompted the publication of a sensationalist exposé in The Oregon Journal in November of that year. But while the article may have hastened the completion of buildings on the new Poor Farm on a rural parcel of land twelve miles east of Portland, it was not the cause of relocation: the county had already purchased the land in what is now the city of Troutdale and begun construction on it the previous year.

In retelling the story, it is easy to mistake causality with correlation and assume that the charities' investigations prompted the relocation. This is inaccurate, however, as the county began searching for a new location in 1908, two years prior to the charities' damning report. ${ }^{57}$ Contemporary reports from newspapers conflicted in their description of conditions at the farm in its last years. In April 1901, for example, the grand jury report, as printed in The Oregonian, found the Poor Farm "in first-class condition" and offered no recommendations for improvement. ${ }^{58}$

But even if the reality was as terrible as that described in The Oregon Journal exposé, it is entirely possible that authorities allowed the situation to deteriorate because they knew the relocation was imminent. No matter the conditions at the farm in 1910, the

${ }^{56}$ Nesbit, Vintage Edgefield (1995): 4.

${ }^{57}$ In her book, Vintage Edgefield, local Troutdale historian Sharon Nesbit wrote that "deplorable" conditions at the existing Hillside Poor Farm "hastened construction" on the new farm in Troutdale. Nesbit did not address why the county purchased the land in Troutdale. The same story is repeated in the Oregon Encyclopedia entry by Sharon Nesbit, "Multnomah County Poor Farm (Edgefield)" and in the 1990 National Register nomination of the Edgefield Farm. In both the latter cases, the wording foregrounds the charitable organization report, therefore giving the impression that abysmal living conditions were the primary impetus behind the move. Retelling the story in less formal means, such as historical blogs and government web sites, has often conflated the information and perpetuated the misconception that the 1910 incident caused the relocation. The inmates were moved from the Hillside Farm to the Edgefield Farm in late 1911, so it is easy to understand how this misconception continues. Although, the Progressive Era was rife with reformers, and many Portlanders were concerned about the wellbeing of the Poor Farm residents, my research challenges the tendency to push the relocation neatly into the tent of social reform.

58 "Police Indicted for Night Raids. Grand Jury Condemns Moral Squad," Oregonian, April 1, 1909. 
VNA visit and The Oregon Journal piece did not cause the move. The factors that led to the farm's displacement were more complex and began decades earlier. 


\section{Chapter 2: Parks, Poverty, and Public Good}

In 1922, Mayor George Baker dedicated the new Hoyt Park on the site of the former Multnomah County Poor Farm. The northern 160 acres were devoted to park and playground space and in 1930, city officials hired horticulturist John W. Duncan to create a plan for an arboretum on the site. Planting began the following year. ${ }^{1}$ The southern portion of the old Poor Farm land, roughly 40 acres, was turned into a municipal golf course and used as such until construction began on the new zoo in $1954 .^{2}$ The park was named for commissioner Ralph W. Hoyt to recognize his public service, and to commemorate the pioneer family of which he was a part. ${ }^{3}$ Ralph Hoyt was also a proponent of parks, thus the name reinforced the idea that this park dedication would be a testament to the forward-thinking men of the day who had worked to beautify the city and preserve spaces for public parks.

Two complementary narratives surround the story of how the old Poor Farm land became a public park. One celebrates visionary leaders securing the park for the public good, and the other blames corruption and neglect for the facility's closure. These two stories weave through most histories of the Poor Farm and Washington Park. ${ }^{4}$ Even the official history given by the Hoyt Arboretum relies on both narratives. The organization's

\footnotetext{
1 “The Duncan Plan," Hoyt Arboretum, accessed April 30, 2017, http://www.hoytarboretum.org/collections-and-conservation/the-duncan-plan/. "Riley Summarizes Work of Civic Committee in Aiding Unemployed," The Oregonian, March 10, 1931.

2 "History," Oregon Zoo, accessed October 24, 2017. http://www.oregonzoo.org/about/aboutoregon-zoo/history

${ }^{3}$ Ordinance 42141, City of Portland, November 29, 1922. City of Portland Archives and Records Center.

${ }^{4}$ City Park was renamed Washington Park in 1912. The name change was, at least in part, a response to the Olmsted Brothers suggestion that the name be changed to something more memorable. The space formerly occupied by the Poor Farm was originally named Hoyt Park, and the arboretum is still called Hoyt Arboretum. The zoo and the arboretum were subsumed into greater Washington Park in the late twentieth century.
} 
website explains: "In 1910 scandals involving lax and corrupt supervision and intolerable conditions eventually caused the closure of the facility ... leaders sought to preserve the space as a public park dedicated to the growing and conserving of tree species from around the world." ${ }^{5}$ In the scant literature that exists on the topic, the tendency is to blame the Poor Farm for its own demise.

Neither of these narratives are incorrect, but neither are complete. The role of parks in the dissolution of the old Poor Farm is more complex than existing histories present. Park enthusiasts had, indeed, eyed the land as a potential park site for several decades before their visions became reality. ${ }^{6}$ However, at the time when the new Multnomah County Poor Farm opened in Troutdale in 1911, the future of the old Poor Farm site was still far from certain. In fact, when the county sold the land in 1909, the buyer, local real estate investor B. M. Lombard, intended to develop a high-end residential community on it. Only after Lombard failed to pay taxes on the land, resulting in a years-long legal battle, did the parcel revert back to county ownership in $1916 .{ }^{7}$ Four

5 "History of the Aboretum Part I," Hoyt Aboretum, accessed January 15, 2017. http://www.hoytarboretum.org/about/our-history/. This is an example of the conflation of causality with correlation referenced in chapter 1: contrary to the website's version of events, the deteriorating conditions at the Poor Farm coincided with, but did not cause, the farm's relocation. In an error that should give the reader pause about the site's fact-checking rigor, this page also lists the Poor farm as opening in 1898. In fact, the county purchased the land thirty years earlier, in 1868, and residents moved in about two years later.

${ }^{6}$ Others perhaps cared little for parks in and of themselves and more about what they could mean for business interests. R. B. Curry, a real estate investor, wrote a letter to the Portland City Council in 1891 offering to buy City Park for $\$ 3,000$ an acre. He argued that City Park was too small for the population and the city should buy the Poor Farm and turn it into a park. The city council rejected Curry's offer, saying it was far too low. The same article mentioned that Amos King had 108 acres adjoining City Park on the west and that he was ready to sell to the city for $\$ 3,000$ per acre, but this never happened. "Wants the City Park," The Oregonian, May 7, 1891.

${ }^{7}$ The outcome of the 1909 sale was debated for several years. The Oregonian reported that the County Court sold the land on June 18, 1909 to W. A. Spanton, a real estate dealer, for \$154,530. The county maintained the right to use the buildings for six months while the new Poor Farm was being built. In addition, the court granted a franchise for 2,000 feet along Barnes road for an extension of the streetcar line, which would connect with Washington Street (today Burnside). The Spanton Company reportedly 
years later, the city leased the land from the county with the intention to use it as a park. ${ }^{8}$ In 1922, the county donated the poor farm land to the city. ${ }^{9}$

The growing interest in municipal parks and desire to establish Portland as a respectable, mature city did place increasing pressure on the county to move the Poor Farm away from the West Hills, but it was not a simple cause and effect scenario. In other words, it is impossible to trace a direct a line from the early interest parks promoters expressed in the site and the dedication of Hoyt Park in 1922. The relationship between the parks movement and the Poor Farm is more complicated, but it nevertheless had important consequences for the farm's fate.

\section{An Increasing Interest in Parks}

By the turn of the twentieth century, Portlanders, like other city dwellers across the nation, were captivated by the ideas of the City Beautiful movement. Better living through city planning was en vogue, and cities across the country poured resources into

intended to develop a high-end residential addition on the site. The newspaper reported that "Engineer Olmsted" had been tapped to plat the lots. H. R. Reynolds, a representative from the Spanton Company, said that in order to create the upscale neighborhood, restrictions on housing would be enforced and construction of houses costing less than 3,000 or 4,000 dollars would not be permitted. Also, no lot in what the paper called the "Poor Farm addition" would be sold for less than $\$ 1,000$ ("County Poor Farm Sold," The Oregonian, June 19, 1909;

The initial purchase actually had five claimants, who proceeded to sell and maneuver various shares. Before the deed could be issued, a Frank Bollam brought a lawsuit against the five claimants, as well as County Judge Webster and County Commissioner Lightner, charging that the men had colluded to keep the price of the land down. Bollam lost and the court dissolved the injunction against handing over the deed, but the county still did not know who was the rightful owner ("Deed is Withheld," The Oregonian, 8/24/1909; "Spanton is in Lead," The Oregonian, 9/16/1909). The matter went to court with two parties claiming a $3 / 5$ share of the land. Finally, B. M. Lombard was able to buy out the other claimants. Lombard also intended to turn the land into a wealthy residential neighborhood, putting it on the market with an adjoining 280 acres that he also owned ("Poor Farm Goes to B. M. Lombard," The Oregonian, May 7 , 1910.)

In 1915, the county foreclosed on Lombard, for failure to make payments. "Poor Farm Deal Biggest of Week," Oregonian, June 6, 1915.

8 "City Fund Dearth Halts Park Plans," Oregonian, November 7, 1920.

9 "Merger Plan Favored," Oregonian, January 13, 1922. 
landscape architecture, public parks, and playgrounds. In 1899, the Oregon legislature passed a law requiring every city with a population larger than 3,000 to assemble a parks board. The board would have authority to purchase land and could raise a special property tax to do so, provided the tax was approved by the voters. ${ }^{10}$ The following year, the first Portland Parks Board eagerly set out to assess the city's current park situation and develop a comprehensive plan for park development.

Park supporters nervously eyed the West Hills as the rapidly-increasing population pushed Portlanders up and over the summits, and houses built on trestles and stilts cropped up on the hillsides. Keen to act before it was too late, park proponents, such as banker Colonel Lester Leander Hawkins and architect Ion Lewis, presented their case that the best use of the city's western peaks and canyons was as municipal parks. ${ }^{11}$ Their position rested on the belief that the hillsides should not be used for residences, either private or county-owned.

Again and again, the Park Board stressed the need to preserve natural land. By this time, much of the surrounding forests had been felled, but Hawkins, Lewis, and likeminded Portlanders insisted that the remaining landscapes ought to be protected. Certain areas, they contended, were of little use to individuals but could greatly enhance the general welfare of Portlanders as park land. They expressed an especial interest in hilltops, valleys, and riverfronts and were enthusiastic about following the actions of

10 "An Act to Provide for Park Commissioners, and the Acquisition of Lands for Parks, and the Management Thereof" February 17, 1899, reprinted in the Report of the Park Board for 1901, City of Portland Archives. The tax was not to exceed half a million dollars in one year.

${ }^{11}$ Colonel L. L. Hawkins was a banker by occupation, but he was also highly active in the city's development and planning around the turn of the twentieth century. As was the case in most cities of the time, businessmen, politicians, and planners were often drawn from the same groups of influential citizens. For more on planning in Portland, see Carl Abbott's Portland: Planning, Politics, and Growth in a Twentieth Century City (Lincoln: University of Nebraska Press), 1983. 
Eastern cities. They hoped to do so by hiring a professional landscape architect from the East Coast. ${ }^{12}$

The first Report of the Park Board in 1901 identified the Poor Farm as desirable park space. Hawkins and Lewis gave an account of the city's current park holdings, in which they suggested: "Perhaps the area of the present County Farm (160 acres) can be, by arrangement with the county, treated as a public park." ${ }^{13}$ At this early date in the development of Portland Parks, leaders of the movement recognized the Poor Farm land as a valuable location. However, the Board was not ready to purchase the land from the county.

They did suggest purchasing 60 acres directly west of City Park, then owned by the Water Commission, which housed two city reservoirs. The Board members recorded their strong support of acquiring the parcel, noting that this reservoir land would be "a crowning attraction" to City Park. ${ }^{14}$ The addition of the Water Commission land would bring the city's principle pleasure ground even closer to the Poor Farm.

The first Park Board report made clear with its catalogue of current parks that Portland's holdings were meager and disjointed, especially compared to those of other cities. For one thing, Portland was late to the game: Minneapolis, for example, had enacted a comprehensive park plan in 1886, and Seattle's Parks Commission published its first report in $1891 .{ }^{15}$ A history of the parkland acquisition prior to October 1900 included ten acres of park blocks and plaza blocks donated by Daniel Lownsdale and

\footnotetext{
${ }^{12}$ Report of the Park Board, 1901, 10, Portland Archives and Records Center.

${ }^{13}$ Ibid 10.

${ }^{14}$ Ibid 7-8.

${ }^{15}$ Matthew Klingle, Emerald City: An Environmental History of Seattle, (Newhaven: Yale University Press, 2007) ProQuest Ebook Central.
} 
W.W. Chapman. The park blocks were originally contiguous, but due to dispute over rightful ownership after the Lownsdales died, six of the blocks were lost to development. ${ }^{16}$ The other extant parks in 1900 included Terwilliger Park (no longer extant), City Park (now Washington Park), Holladay Park, and Governor's Park, Macleay Park, Columbia Park ${ }^{17}$ and a few "fractional blocks" in Ladd's Addition. Of these, Macleay dwarfed the others at 107.78 acres, while City Park came in at a respectable 40.78 acres and Columbia Park, which Portland acquired after it merged with Albina (and East Portland) in 1891, ranked third at 29.46 acres. ${ }^{18}$

The massive Macleay donation served as an impetus for the city to set about planning with intention. ${ }^{19}$ Macleay Park was by far the largest, but it was also the least developed, having just been donated three years prior in 1897. City Park, in contrast to Macleay, was formally developed and wildly popular by the turn of the twentieth century. The Park Board's report noted the difficulty city leaders had in convincing Portlanders of its worth when the city purchased the land in 1871: "The purchase was at first regarded by most citizens with disapprobation or contempt. It was with great difficulty that even the most beggarly appropriations were obtained for grading and clearing the surface." 20 By the time the Park Board wrote their first report, pride in City Park shone through the

${ }^{16}$ Chet Orloff, "Portland Park Blocks," in Oregon Encyclopedia, https://oregonencyclopedia.org/

${ }^{17}$ Portland gained Columbia Park in its annexation of the City of Albina; it was the citizens of Albina, not Portland, who set aside this land.

${ }^{18}$ Report of the Park Board for 1901, 6-7. E. Kimbark Maccoll wrote that in 1902, Portland owned only 136 acres of park land, or $1.5 \%$ of all city land. This he compared to Hartford, Connecticut, a city of comparable size, that had devoted $15 \%$ of its land to parks. However, Maccoll must not have been counting Macleay land in his number. E. Kimbark MacColl, with Harry Stein. Merchants, Money, \& Power: The Portland Establishment 1843-1913. (Portland, OR: The Georgian Press, 1988): 361-362.

${ }^{19}$ William Hawkins III, The Legacy of the Olmsted Brothers in Portland (Portland, OR: published by author, 2014): 31 . Hawkins III wrote that the Macleay donation prompted the city to appoint a Park Board. At the same time, the state legislation passed two years after the Macleay donation required cities over 3,000 in population to establish a park board. Perhaps both factors played a role.

${ }^{20}$ Report of the Park Board, 1901, 7, City of Portland Archives and Records Center. 
text: "At the present time it may be said that there are few parks of the size anywhere to rival the City Park for picturesque beauty and variety in contour and development."21 Indeed, by the first decade of the twentieth century, Portland promoters considered City Park worthy of publicity, as evidenced by the park's frequent appearance in postcards and souvenir books.

City Park may have been beautiful, but it was also crowded. The first Park Board report both boasted and lamented that 100,000 visitors frequented the park each year. The men of the Park Board, as well as other leading figures, were building an argument that the city needed to acquire as much land for parks as possible, to keep up with the growing population.

\section{Public Betterment and the City Beautiful}

In creating a Park Board, Portland was following national trends in governance that valued systematic city planning and comprehensive park systems. In West Coast cities, proponents of city planning were often businessmen, who saw planning as a means to surpass rival cities. In most coastal cities, including Portland, Oakland, and Seattle, merchants were often the most fervent supporters of planning efforts (in Los Angeles, it was real estate men). Businessmen - especially merchants, but also bankers, such as Colonel Hawkins, and industrialists — sought to heighten the economic power and reputations of their cities. A smartly-designed city would attract investment, capital, industry, and people. ${ }^{22}$

\footnotetext{
${ }^{21}$ Report of the Park Board, 1901, 7. City of Portland Archives and Records Center.

${ }^{22}$ Mansel Blackford, The Lost Dream: Businessmen and City Planning on the Pacific Coast, 1890-1920, (Columbus, OH: Ohio State University Press, 1993): 3- 4.
} 
As the country embraced professionalization in a range of fields, as well as comprehensive urban planning, the Portland Park Board placed great faith in the trained eye of an expert landscape architect. Time was of the essence: not only did wealthy Portlanders wish to demonstrate their city's status as thoroughly modern, they felt a real fear that inaction would result in the loss of potential parkland to development and speculation. Further, increased property values might soon price the city out of the most desirable areas. ${ }^{23}$

Adding additional parks, the Park Board believed, would benefit the health and wealth of the city: "The uses of parks are not confined to the pleasure and relaxation of the few, nor of an idle, floating population. The beautifying of the city as a whole, the increased healthfulness of the people, the higher values to all property, the opening of beautiful suburbs and the true expansion of the commonwealth itself are involved." 24 The men of the Park Board argued that municipal pleasure grounds were egalitarian in nature and salutary for mind, body, and spirit. An abundant park system signaled middle class, respectable, white society. Thus, Portland's men of influence believed, it was their duty to secure lands for the park system and appropriate funds for their upkeep.

Much of the land that the Park Board considered ideal for a system of parks was privately owned, though not necessarily developed. In the case of the Poor Farm, the land was owned by the county and just outside the city limits. The Park Board believed that

${ }^{23}$ This fear was well-founded and in fact, delay of only a few years rendered unaffordable much of the land identified in the Olmsted Plan. Despite widespread applause and publicity in 1904, no action was taken on the Olmsted Plan for two years, as civic and business leaders poured efforts into the Lewis and Clark Exposition. In 1906, a group of businessmen and civic leaders pushed through a one-million-dollar bond for park development, and voters approved it the following year. The money was tied up in legal procedures and when it became available in 1909 and 1910, real estate inflation had caused a drastic decline in buying power. Abbott, Portland (1983): 60.

${ }^{24}$ Report of the Park Board, 1901, 11. 
landowners could be persuaded to negotiate the sale or donation of their land, if they understood the increased property values that an adjacent park would bring. The parks movement in Portland trailed that in Eastern cities by about sixty years. Thus men like Colonel Hawkins, Ion Lewis, and Reverend Thomas Lamb Eliot could draw on the experience of cities such as New York and Boston when considering how to negotiate with landowners. This experience taught that where a park was built, the surrounding property values increased dramatically — to the delight of wealthy landowners and the dismay of poor residents. ${ }^{25}$

Due to its picturesque surroundings, the Park Board wrote, Portland had not felt as much pressure as other cities to preserve parklands ${ }^{26}$ However, with the increasing population and land prices, they argued, doing so was now vital. Board members argued that, "A city like Portland, to which nature has been more prodigal in climate, diversity and grandeur of surroundings than any other in the country," should have "a park system embracing riverside, mountains and plains, and connected by wide boulevards." Such a park system "would go far to make this the most beautiful city in the world." ${ }^{.7}$ Clearly the men of the Park Board felt Portland was an exceptional city, in large part due to its scenery. Over the next ten years, the parks planners would be forced to consider how the Poor Farm, situated as it was along the coveted rim of the West Hills, fit into this

\footnotetext{
${ }^{25}$ For a discussion of the parks movement and its relationship to property values, real estate, and tax base in antebellum New York City, see "Unequally Green," in Catherine Mcneur's Taming Manhattan.

${ }^{26}$ Portlanders were not the first Americans to feel this exceptionalism in regard to the location of their city. Ninety years earlier, in 1811, New York City's special commission on parks made a similar argument about Manhattan; that is, its situation between two vast bodies of water meant air would circulate freely and thus health would flourish. Catherine McNeur, "Parks, People, and Property Values: The Changing Role of Green Spaces in Antebellum Manhattan," Journal of Planning History 16 (2): 98-111. Doi: https://doi.org/10.1177/1538513216657563

${ }^{27}$ Report of the Park Board, 1901, 11-12.
} 
magnificent vision.

\section{The Olmsted Plan}

In 1903, at the request of Park Board chair and Progressive activist Reverend Thomas Lamb Eliot, the city commissioned the Olmsted Brothers firm to conduct a review and draw a plan for a comprehensive park system. The 1903 Olmsted Brothers Report described a series of neighborhood parks connected by wide boulevards and parkways. In addition, it called for the maintenance of large swaths of rustic land. The Olmsteds envisioned the West Hills, in which the Poor Farm was located, as a series of interconnected parks and wild preserves, joined by a hillside parkway. In architectural landscape vocabulary of the time, a parkway referred to a scenic thoroughfare, designed to offer viewpoints and take advantage of natural beauty. Parkways were flanked by undeveloped strips of land, so as to preserve the feeling of being removed from the industrial city. 


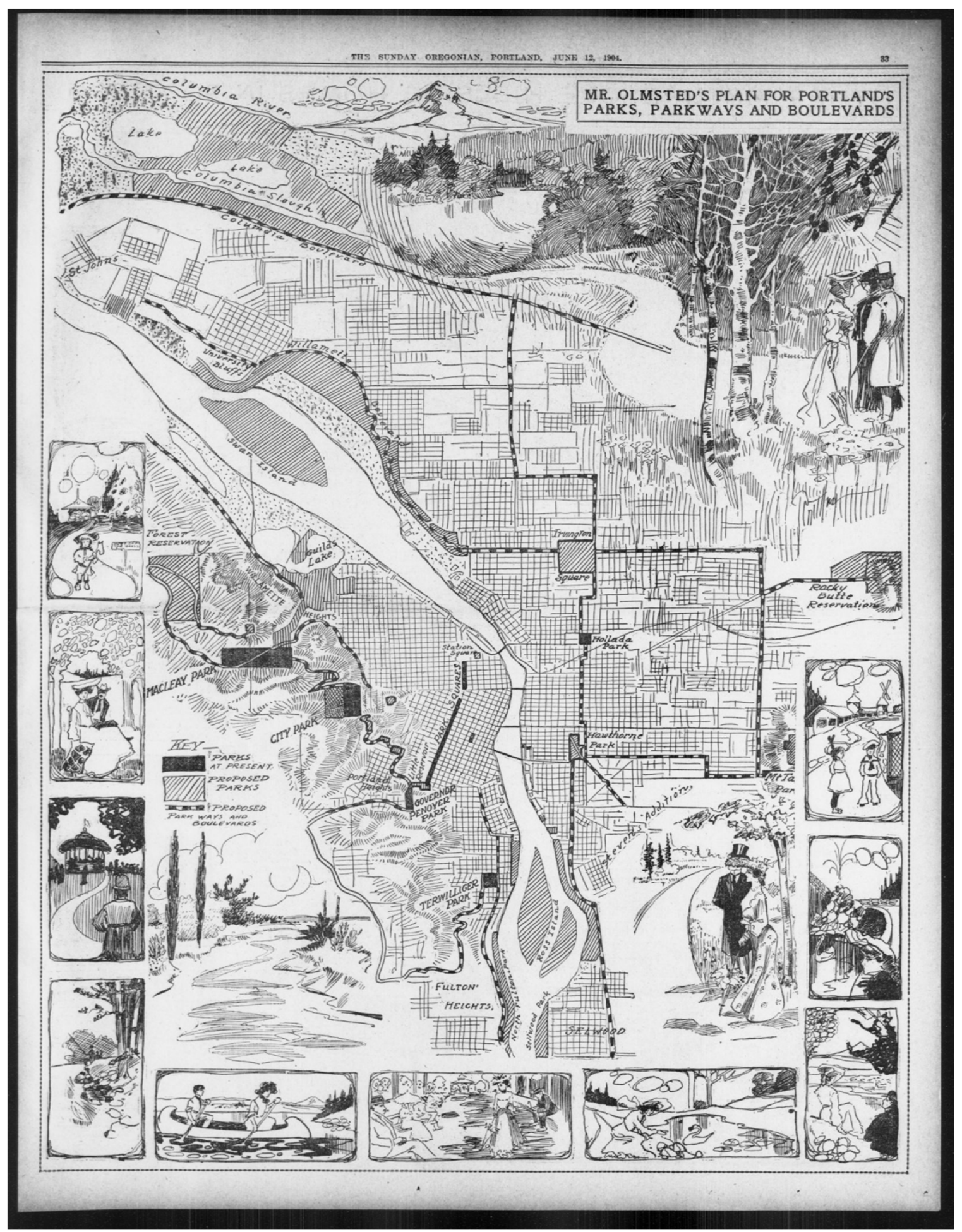

Figure 3. Olmsted Plan for Parks and Boulevards, as envisioned by The Oregonian. Printed in The Oregonian June 12, 1904. The Poor Farm, not shown on this drawing, would have been roughly under the key on the left hand side. 


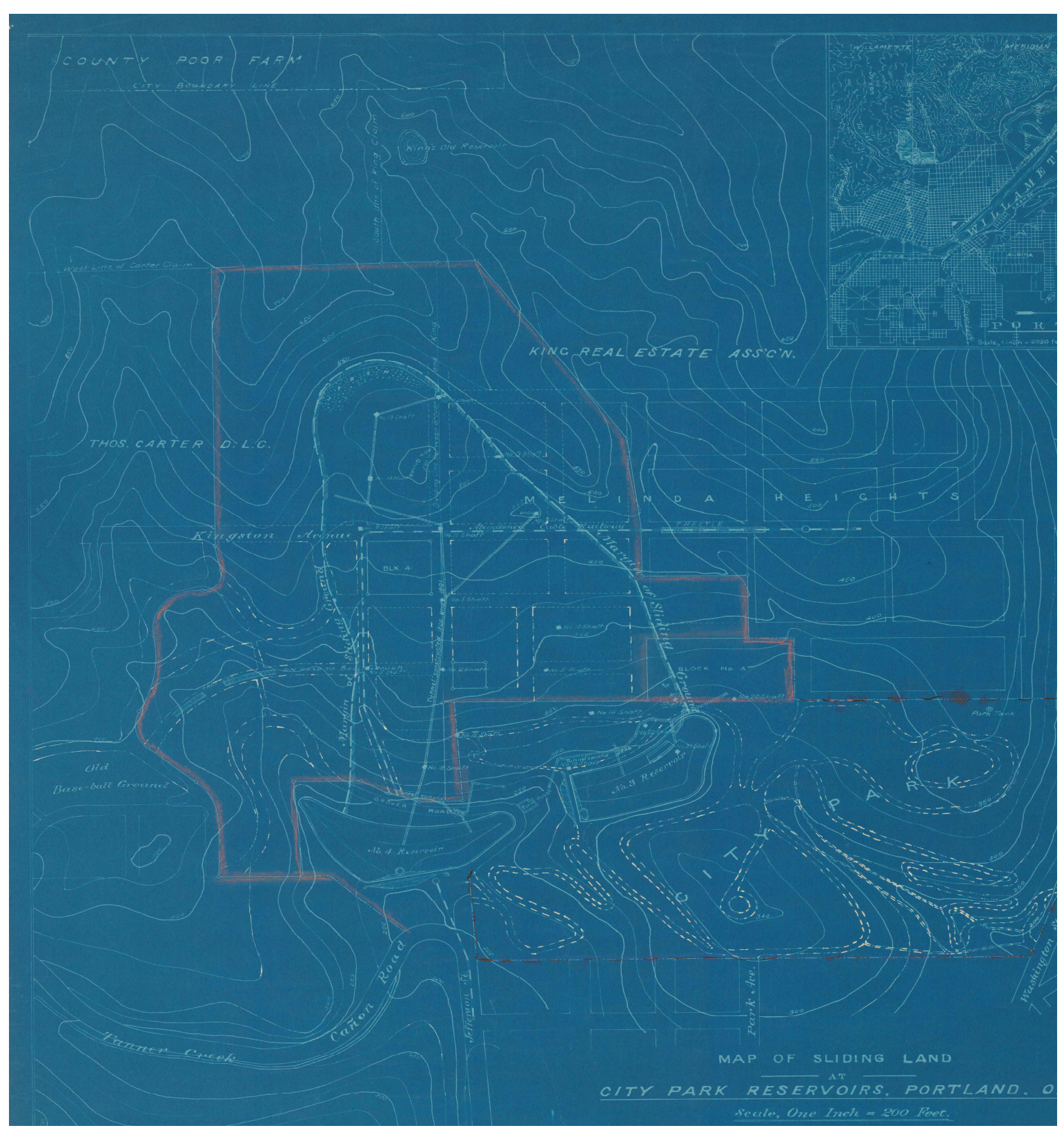

Figure 4. Contour Map of Sliding Lands Near Poor Farm and City Park This map was apparently used by the Olmsted Brothers Firm in creating their plans for Portland Parks. The County Poor Farm is clearly visible, and in close proximity to City Park. The red polygon seems to indicate a parcel of land that John Charles Olmsted was considering advising the city to acquire. [Image courtesy of Olmsted National Historic Site, Brookline, MA.] 
Figure 5. Map of Portland with Proposed Parkways Drawn in Red.

The red pencil indicates that the proposed parkway ran close to the County Farm, but at this time, the Olmsted Firm was not explicitly proposing acquiring that parcel. [Image courtesy of Olmsted National Historic Site, Brookline, MA] 


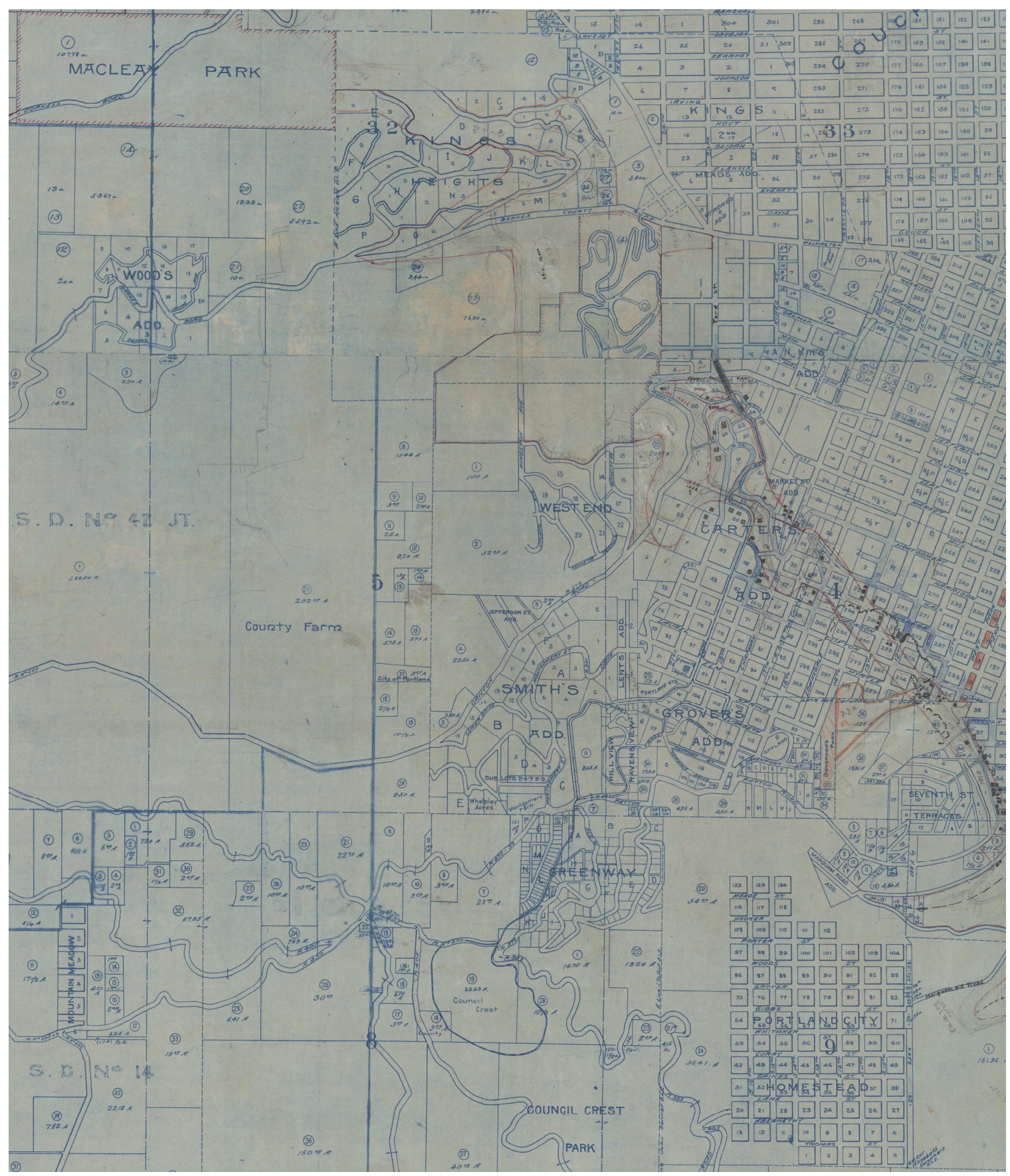

Figure 6. Map of Portland with Proposed Parkways Drawn in Red, Enlarged Section. The figure below is a zoomed in, cropped section of Figure 5. A triangle from Macleay Park to City Park to Council Crest Park would enclose the County Poor Farm, a fact which illustrates the Poor Farm's placement amongst an increasingly park-abundant area. 
The Olmsted Plan reconfirmed the Park Board's assertion that a developed park system was a hallmark of civilized, refined society. Further, the respectable forms of recreation parks provided reinforced upstanding, middle-class values. The Olmsted Report opened with a lengthy introduction outlining the firms' principles regarding landscape architecture, which the Olmsteds believed developed the "healthfulness, morality, intelligence and business prosperity" of city dwellers. ${ }^{28}$ Thus, the Olmsted firm and the Park Board argued, municipal pleasure grounds both signified, and perpetuated, a solid, respectable society.

Even as Portland's Park Board eyed the city's western hills as an ideal setting for the spine of their new park system, the Poor Farm's proximity posed a problem. On the West Side, the Olmsted Plan laid out a series of parks and connecting parkways from River View Cemetery (and the land south of it, if possible) up into and across the West Hills, connecting with the vast reserve of what became Forest Park. Olmsted's drawings, as well as the maps inspired by them, imagined a hillside park system that cut within a mile or less of the Poor Farm land. John Charles Olmsted wrote: "City Park should be extended on the west to form a good connection with the Poorhouse Farm, a portion of which may be eventually annexed to the park." ${ }^{29}$ If the whole Poor Farm could not be acquired, Olmsted suggested, perhaps a pleasure drive could run through it, connecting City Park to the western hilltops. These peaks would offer "beautiful rural views to the westward" as well as views of the city. ${ }^{30}$

${ }^{28}$ Report of the Park Board for 1904, Including the Report of the Olmsted Brothers Firm for a System of Parks and Boulevards, 1904, 22.

${ }^{29}$ Ibid 73-74.

${ }^{30} \mathrm{Ibid}, 74$. 
The Olmsted Report clearly shows that John Charles Olmsted saw the Poor Farm land as part of the scenic West Hills landscape. Annexing the land for parks would secure more fine viewpoints, and also relieve pressure on City Park. Such an addition would help rectify the overcrowding caused by the fact that, in Olmsted's estimation, the City Park had not been properly laid out. Portland's treasured pleasuring was already "taxed to its utmost, especially on holidays and pleasant Sundays in summer." ${ }^{31}$ Its popularity was testament to "how valuable for purposes of recreation additional large areas of hillside land southwest of the city would become in the course of time, as the population grows." ${ }^{32}$ According to Olmsted, the increasing population would soon demand more park land, and the southwest hills were a natural choice for the purpose.

Beyond beauty, parks offered sanitary benefits, the firm wrote, not only through fresh air and exercise, but also through improved drainage. The report recommended obtaining land with adequate drainage while the land was cheap, in order to prevent the cost of diverting or subverting creeks in the future. Such foresight would save the city money by allowing for natural drainage, and it would also thwart the probable construction of cheap dwellings. The Olmsteds could point to Leverett Park in Boston as an example of park dedication saving a marshy area from what "would otherwise have been depreciated by the erection on the low lands of the cheapest class of dwelling or by ugly factories, stables and other commercial establishments." 33 If not for turning the cattail marsh into a park and lake, the beautiful landscape would have become blighted

\footnotetext{
${ }^{31}$ Report of the Park Board, 1904, 69, City of Portland Archives and Records Center.

32 Ibid, 69.

${ }^{33}$ Report of the Park Board, 1904, 29.
} 
with "only the poorest class of houses, stables, and the like." ${ }^{34}$ Throughout the Olmsted report, and the broader discussion of parks creation in Portland and nationwide, visionaries elevated certain uses of land over others.

In addition to privileging one type of land use, reformers and developers also privileged one class of people over another. Throughout the Olmsted report, the annual Park Board reports, and discussions in The Oregonian, the theme resurfaced that if desirable lands did not become parks, or in some cases even if they did, an expensive neighborhood development might be tolerated, but "flimsy" dwellings erected in haste would not. The men of these organizations might entertain a "good neighborhood" on land that would otherwise go to the park system (or sometimes alongside or even in it, in the case of Arlington Heights), but the "poor class" of dwellings would be an inappropriate use of the land.

Ideas about the best use of land, and who could rightfully claim its use, were informed by values and monetary considerations. The Olmsted firm wrote that if a city had ample land and scenic areas, it should try to create as a grand a park system as possible. Issuing bonds would prove lucrative, "provided there is a reasonable probability of attracting to itself thereby well-to-do and wealthy families," because their income and property taxes would more than pay back the initial investment. ${ }^{35}$ Further, the Olmsted Report urged, park loans were one of the best investments a municipality could make; park construction would almost always increase the value of the land and of adjacent properties and dwellings.

\footnotetext{
${ }^{34}$ Ibid, 29

${ }^{35}$ Ibid 29.
} 
The Olmsted report reflected the City Beautiful belief that a sophisticated citizenry held a civic duty to augment the city's beauty and attractiveness, especially its appeal to strangers. Neither the Olmsted firm nor the Park Board explicitly said the Poor Farm did not deserve the scenic patch of land it occupied, but their approach to designing a parks system treated it as an impediment. To be sure, the Poor Farm was just one of many currently-unavailable parcels they believed could and should be obtained for park purposes. In contrast to privately held land though, the city actually did acquire the Poor Farm land for park use within a couple decades.

The Olmsted expertise and the Park Board's enthusiasm were insufficient to materialize the dreams of a vast, interconnected system of parks. The reluctance of politicians and taxpayers to pay for the land, coupled with the plodding pace of government action, meant that much of the land the first Park Board members sought to preserve for parks instead went to private development and industry. ${ }^{36} \mathrm{~A}$ continuous park system was never realized, but a map of present-day Portland shows that a significant portion of the Olmsted plan was implemented, in fits and starts, on the west side of the city.

\section{The Limits of Planning}

Although neither the Olmsted firm nor the Park Board ever described it in these

${ }^{36}$ In keeping with contemporary principles of landscape architecture, the Park Board suggested that wetlands, waterfronts and bluffs should be preserved as parks. The1904 Olmsted Plan identified the Columbia River slough as good park grounds, but the slough instead became a site of industry and heavy pollution. For an examination of environmental inequality in the city's use of the Columbia Slough, see Ellen Stroud, "Troubled Waters in Ecotopia: Environmental Racism in Portland," Radical History Review 74: 65-95 (1999). 
terms, one stark fact about the Poor Farm land would have been glaringly obvious to all: no matter how beautiful the adjacent parks, the county-owned Poor Farm would never add taxable value to the City of Portland. If the city wanted to transform the West Hills into a quilt of scenic pleasure grounds and wealthy residences, they would need to do something about the Poor Farm.

Despite the Olmsteds' storied legacy in Portland, it would be a mistake to overstate their influence, or that of the Park Board, in displacing the Poor Farm. Scholars have long debated the extent to which planning influenced politics, as politicians are bound by budget and constituents while planners theoretically operate according to impartial laws and principles. ${ }^{37}$ In the case of Portland, the Olmsted Plan was only partially realized, due primarily to financial constraints and the unwillingness of independent landowners to relinquish their land. While the City was able to push through a park bond in 1906, the funds did not become available right away. Writing to Ion Lewis in December 1907, John Charles Olmsted stated his fear that property values were rapidly putting potential park lands out of reach, and offering a pared down version of the plan, identifying the most essential elements, which he felt would provide the most benefit for the cost. ${ }^{38}$ By the time the city was able to move on acquisition of the lands the following year, increasing real estate prices had made even much of the trimmed plan unattainable. ${ }^{39}$

Nevertheless, the reports of the Park Board and the Olmsted Brothers Firm

\footnotetext{
${ }^{37}$ Carl Abbott, Portland (1983): 9-10.

38 John Charles Olmsted to Ion Lewis, December 6, 1907. Letter. In Meeting Minutes of the Portland Park Board Book. City of Portland Archives and Records Center.

${ }^{39}$ Ion Lewis to John Charles Olmsted, September 4, 1908. Letter. In Meeting Minutes of the Portland Park Board Book. City of Portland Archives and Records Center.
} 
demonstrated changes in the city that would lead to the farm's relocation. Both the Park Board reports and the Olmsted Plan suggest the Poor Farm land would make a nice addition to the city's park system, but neither insisted on its acquisition. The writings of these parks enthusiasts from the opening decade of the twentieth century reveal a shifting view of the terrain, however. Where once the Poor Farm was up a creek and over a hill, seemingly in a removed, bucolic setting, now it was pushing up on the borders of hot real estate markets. In addition, the City Park was taxed to capacity and the surrounding land began to look like a potential pressure valve.

The question that underlay these reports, occasionally surfacing directly, was, to what purpose should this land be used? Repeatedly, the authors of these reports spoke of public parks as an unassailable public good. Yet, in discussing the potential for development, the men of the Park Board, and especially the Olmsted Brothers Firm, allowed for the possibility of high-end residential developments. Whether this privileging of expensive property came from prima facie elitism, or merely a tendency to assess in terms of cost-benefit analysis to the city, the dominant view was that the Poor Farm degraded the area's value rather than augmented it. Likely, the Olmsted firm preferred to envision a park system without the Poor Farm, which contributed no taxable value to the city and brought pleasure ground visitors into close contact with poverty, degeneration, and disease. 


\section{Chapter Three: The Boom Years}

Lawrence West was a 23-year-old laborer when he landed in the Poor Farm in January 1901. Likely as a result of his condition, syphilis, West was admitted to the Hospital rather than the Poor Farm proper. The single, young man stayed at the Poor Farm grounds until September 1901, when he "went to hop yards" voluntarily to work the harvest. ${ }^{1}$

From 1906 to 1913, Portland experienced a boom that reshaped the city in such a dramatic way that the Poor Farm, situated as it was off Tanner Creek in the Tualatin Hills, was now close to the center of town. Psychically, the Poor Farm was too ramshackle and dilapidated to be integrated into a City Beautiful metropolis. Physically, as land values skyrocketed in Portland, would-be developers and their supporters chafed at prime real estate being squandered, as they saw it, on social welfare.

Like other western cities, Portland came into its own as a modern city from the closing years of the nineteenth century into the first decades of the twentieth. Portland's tremendous growth in population, finance, and building in the early twentieth century, created anxiety for the city's residents - as it did in urban areas up and down the coast. The surge in population, industry, and the built environment coincided with increased attempts to impose order on growth—both financial and physical.

West Coast cities, such as Oakland, Seattle, San Francisco and Los Angeles, all recruited professional planners in the opening decades of the twentieth century to draft

\footnotetext{
${ }^{1}$ Admissions Ledger for the Multnomah County Hospital and Poor Farm. Entry Date January 26, 1901. Entry Number 1424. Multnomah County Archives, Portland, OR.
} 
comprehensive plans for city development. Proponents of city planning, primarily businessmen and their political allies, described the predicted benefits of planning in speeches and editorials. A well-ordered city, they argued, would bring beauty, improved morality, civic virtue, and financial gain. ${ }^{2}$

Competition with regional rivals drove much of the push for growth and development - and planning — in Western cities of the Progressive Era. As New York and Boston, or Philadelphia and Baltimore, had done a century earlier, Pacific Coast cities fought for financial, commercial, and cultural supremacy in the late nineteenth and early twentieth centuries. With the Panama Canal under construction beginning in 1903 , businessmen along the coast jockeyed for lead position to capitalize on the increased trade the canal's opening would bring. ${ }^{3}$

In Portland, this coming of age involved a flurry of identity building. Some of the resulting developments, such as the planting of two landscaped rose gardens and the creation of the citywide Rose Festival, were the direct result of deliberate planning by professionals and businessmen. Others, such as the construction of Pittock Mansion, were private enterprises, made possible by the economic boom, that became entwined with the city's identity over time. ${ }^{4}$ Portlanders attempted to redefine their city in both absolute and

\footnotetext{
${ }^{2}$ For a discussion of city planning in Oakland, San Francisco, Los Angeles, Seattle and Portland, see Mansel Blackford, The Lost Dream: Businessmen and City Planning on the Pacific Coast, 1890-1920 (Columbus: Ohio State University Press, 1993): 15-20. Blackford assessed the planning movement in these cities through the framework of organizational synthesis. He found that this framework, which viewed city planning in the early twentieth century as the product of late nineteenth-century business organizations and associations, is useful but incomplete. The concept overreaches, according to Blackford, because it assumes that business interests all acted in unison; in reality, Blackford argues, business interests represented a broad range of people and opinions.

${ }^{3}$ Blackford, The Lost Dream (1993): 15-20.

4 The Peninsula Park Rose Garden, a sunken formal garden designed by Emanuel T. Mische, opened in 1912, the International Rose Test Garden at Washington Park in 1917, and Pittock Mansion
} 
relative ways: planners and civic leader sought to create a city of world class beauty and design, and bankers, merchants, real estate developers, and other businessmen pushed to establish Portland as the regional hub over Denver, San Francisco, and especially Seattle. In the new Portland, there would be no room for last century's Poor Farm.

\section{Keeping up with the Competition}

In the last decade of the nineteenth century, Portland boosters wanted to attract more people. Portland was a regional powerhouse, but its population was too small to support aspirations of being a national player. In 1890, Portland's population was less than half that of Denver, and less than a sixth that of San Francisco. ${ }^{5}$ Even worse in the eyes of merchants and bankers, the city seemed to be losing ground to Seattle. Although Portland doubled its population in the last decade of the nineteenth century, and then again in the opening decade of the twentieth, Seattle grew even more rapidly. The Emerald City did not edge out Portland as the largest city in the Northwest until 1910, but Portland businessmen felt increasing pressure from the northern neighbors beginning in the 1890 s.

While Portland struggled to regain financial stability after the panic of 1893 , which hit Denver especially hard, Seattle was able to recover more quickly by promoting itself as the jumping off point for the Yukon Gold Rush of $1896 .{ }^{6}$ By the middle of the decade, it was on its way to becoming the international hub of the Northwest, the

finished construction in 1914.

${ }^{5}$ Thomas J Noel and Barbara S. Norgren, Denver: The City Beautiful and its Architects, 18931941 (Denver: Historic Denver, Inc., 1987): 2. In 1890, Denver's population was 106,713, second only to San Francisco, at 298, 997, in all of the West.

${ }^{6}$ Abbott, Portland (1983): 33. 
gateway to Alaska, and to the East. Fearing they would soon lose their primacy as the region's commercial and shipping center, Portland businessmen began to organize.

Local boosters emphasized the city's perfect placement to serve as the regional shipping point for the Northwest's natural bounty. The first Portland Chamber of Commerce bulletin described the city's geographic advantage: “The geographic position of Portland and the immense territory of rich country tributary to it has made the city a strong commercial center and gained for it the title of 'Prosperous Portland."7 Further, as a 1907 souvenir book sought to demonstrate, Portland's "beautiful and commodious" harbor was "the envy of the Puget Sound cities." shipped more wheat annually than the Puget Sound cities combined. ${ }^{9}$

These souvenir books, many of which were published by the Portland Chamber of Commerce, cited Portland as the major shipping port for cattle from Eastern Oregon and fruit and wheat from the central Inland Empire. ${ }^{10}$ The Willamette River, for its part, carried agricultural produce from its fabled fertile valley for distribution through Portland to the region and beyond, to the Pacific Rim. Seattle and Tacoma had no such rivers to supply their ports, Portland boosters wrote. ${ }^{11}$

In addition to occupying the best geographic position among Western cities, Portland was also the most respectable, the most civilized, and the most "eastern,"

${ }^{7}$ Chamber of Commerce Bulletin for July 1904 (Portland: Portland Chamber of Commerce, 1904). City of Portland Archives and Records Center.

${ }^{8}$ Introduction to Portland, Oregon: The City of Roses, (Portland: The Portland Post Card Company: Portland, Oregon, 1907). City of Portland Archives and Records Center.

${ }^{9}$ Including Seattle, Tacoma, and Olympia.

${ }^{10}$ At the turn of the twentieth century, Washington and Idaho boosters used the term "Inland Empire" to refer to agricultural lands centering in Spokane. Inland Empire also refers to areas of San Bernardino County, California.

${ }^{11}$ Abbott, Portland (1983): 35. 
according to its promoters. Compared to the raucous and rowdy San Francisco and upstart, precocious Seattle, middle-class Portland seemed to residents a community of intellect and refinement—a city of "245,000 happy, contented, and prosperous souls." 12 The solid, sober image that boosters projected was that of "a city of homes" and "a city of roses. ${ }^{13}$ In promoting middle-class respectability, Portland business leaders were following the likes of Denver and Oakland, whose own promoters were trying to distance their cities from the boom-and-bust, bachelor society image that would-be investors might still have associated with the frontier. ${ }^{14}$ In addition, Portland businessmen at the dawn of the twentieth century were concerned with creating new opportunities for profit while protecting existing investments. ${ }^{15}$ Portlanders were determined to grow their city. Only a certain type of growth, however, was considered a worthy pursuit: civic promoters did not want their city filling up with "the pauper element."

Despite the region's undeniable bounty, and infrastructural improvements that facilitated increased movement of natural products, the number of indigent men and women continued to grow. Ledgers of admission to the County Hospital and Poor Farm recorded a steady increase in between 1900 and 1910. The increase at the Poor Farm paralleled an increase in the number of seasonal, unskilled laborers. Further, the farm was far from self-supporting, even in the fertile Western Oregon climate. Food, especially meat, was purchased from suppliers, attempts at growing hay and other grains failed, and

\footnotetext{
${ }^{12}$ Introduction to Portland, Oregon: The City of Roses (Portland, OR: The Portland Post Card Company, 1907), City of Portland Archives and Records Center, Portland, OR.The population cited here is higher than the U.S. Census statistics for 1910, three years after this souvenir book was published.

${ }^{13}$ Ibid.

${ }^{14}$ Blackford, The Lost Dream, 1993.

${ }^{15}$ Ibid 46.
} 
the fuel needs depleted the farm's supply of firewood. Reports of the farm published in The Oregonian from the late 1890s described the quality of the soil as unproductive. In addition, even at times when vegetables were abundant, the county had to pay outside workers to harvest them. ${ }^{16}$ But the harsh reality of life for the county's poorest residents did nothing to dull the enthusiasm of the city's promoters.

\section{The Great Extravaganza}

Early twentieth-century Portland boosterism reached its zenith in the 1905 Lewis and Clark Exposition. ${ }^{17}$ The "Great Extravaganza" transformed the city more significantly than any other event would until at least the first World War. Business and civic leaders in the late nineteenth and early twentieth centuries knew that World's Fairs were a vehicle for showcasing progress. In addition, such an event would bring an immediate influx of cash to the city and would spur development, leading to more profit down the road. Fearful of the growing cities to the North and wishing to capitalize on new markets in Asia and Latin America, leaders such as Oregonian publisher Harvey Scott pushed to make Portland the seat of the West Coast's first World's Fair, thereby solidifying the city's regional pre-eminence.

16 "Defends Mr. Courtney," The Oregonian, April 3, 1904; "Will Raise Vegetables: The Poor Farm Land is Not Suitable for Grain," The Oregonian, September 4, 1896; "Crops on County Poor Farm: Plenty of Food for the Inmates but Labor is "Scarce," The Oregonian, August 3, 1901. Admissions information comes from analysis of the County Hospital and Poor Farm admissions ledger, located at the Multnomah County archives in Portland, Oregon.

${ }^{17}$ Much scholarship, from both amateur researchers and distinguished historians, has been devoted to the Lewis and Clark Exposition. Academics and the local public are still fascinated by the fair. In her 2015 piece for the Oregon Historical Quarterly, Emily Trafford argued that live performances by Japanese and Filipino peoples at the World's Fair provide a space for visitors to engage with, and rehearse, white supremacy. Emily Trafford, "Hitting the Trail: Live Displays of Native American, Filipino and Japanese People at the Portland World's Fair," Oregon Historical Quarterly 116 no. 2 (Summer 2015): 158-195.

Carl Abbott's Great Extravaganza explores in detail the forces that created the Fair and its effect on the city and region. Abbott commented in a 2015 presentation in Portland on the World's Fair that the topic was always a popular one locally. 
Starting in the late 1890 s, wealthy Portlanders lobbied hard to stage the exhibition as soon as possible. Scholars have frequently discussed how elite groups who funded such exhibitions used them to promote their advanced civilization and technology, especially in comparison to the colonies and protectorates that formed their empires. Funders used the World's Fair phenomenon, which saw its peak from the mid-nineteenth through the mid-twentieth century, to promote national identity. ${ }^{18}$ The argument could be made that businessmen also used fairs to engender local and regional identity.

Portland business leaders believed the World's Fair could promote on a grander scale the themes addressed in the Chamber of Commerce literature: Portland as a prosperous metropolis, as the gateway to Asia, and ultimately as a good investment. The event's laborious title—-"The Lewis and Clark Centennial and American Pacific Exhibition and Oriental Fair"- was chosen to underscore the city's role in the new empire. ${ }^{19}$ As local businessman Irwin Mahon cautioned, "Oregon has the army of material with which to achieve glory by capturing the preponderance assured to it in the general affairs of the world, but Oregon can not gain the victory unless it utilizes—and this means work--the opportunity now at its disposal." Men who imagined a grand metropolis for Portland believed the Fair was the vehicle through which to achieve their vision.

Organizers knew the site of the Fair would be a major factor in its success or

${ }^{18}$ Katherine Smits and Alix Jansen, "Staging the Nation and Expos and World's Fairs," National Identities 14 (2), 2012: 173-188; Robert Rydell, All the World's a Fair: Visions of Empire at American International Expositions, 1876-1916 (Chicago: University of Chicago Press, 1987). Rydell argued that American world's fairs served to legitimize American expansionism and imperialism, often through display designed to project American technological, artistic, economic - in conjunction with racial — superiority.

${ }^{19}$ Carl Abbott, The Great Extravaganza: Portland and the Lewis and Clark Exposition (Portland, OR: Oregon Historical Society Press, 2004): xii. 
failure. Businessmen and politicians devoted pages in newspapers and pamphlets to promoting their choice for the Fair's location — and the majority selected City Park. The popular park had been the favorite location for years of planning leading up to the Fair, and the extension of the electric streetcar line to the park in 1904 made it the natural choice for most members of the World's Fair commission. City Park offered many advantages, including the fact that the City already owned forty acres outright and, some members hoped, they could arrange with the water bureau and the Poor Farm to use adjoining land.

Of commission members, Reverend Thomas Lamb Eliot and Colonel L. L. Hawkins, both staunch parks supporters, advocated for the City Park site. Hawkins reportedly believed that Portland's Fair could not compete with other cities' expos in terms of architecture, but held that its unique value would be its scenery. He was especially passionate about the hills flanking the city's west side. Some detractors posited that the City Park location would not offer enough space. Hawkins refuted this, saying that in addition to the 110 acres owned by the city, the adjacent 80 acres owned by the King Real Estate Company could be used for free. ${ }^{20}$ Furthermore, the pieces of the Ladd, Grover, Ainsworth, and Hawthorne estates that lay to the south could be obtained for the fair purposes, he argued. ${ }^{21}$

For Hawkins, Eliot and like-minded advocates of the City Park site, the main

${ }^{20}$ The land owned by the King company was west of the City Park and ran along what is now upper Burnside. When John Charles Olmsted made his report on the city's park system in 1903, he lamented the fact that this land had not been taken in the initial purchase for City Park. Acquiring some of the land, he wrote, would rectify the existing boundaries of the park.

21 "To Name Fair Site, Lewis and Clark Commission Visit Locations," The Oregonian April 28, 1902. 
draw was the view. A 1902 Oregonian article quoted Colonel Hawkins' description of the West Hills generally, and City Park specifically: "Its elevation gives a view of varied scenery that no part of the world can match. This view is numberless in its effects and peerless in its grandeur."22 A few days later, the paper published a lengthy letter to the editor by Judge M. C. George discussing the advantages of locating the Fair at City Park. Judge George waxed poetic about the superiority of the site, saying: "No city in the East ever had such an opportunity for a scenic fair. They all did the best they could on level ground, because they had nothing else. Portland, of all the cities in the Union, has this natural advantage. Such a fair would arrest and attract the attention of the whole country. Will Portland miss her grand opportunity?" Both men praised the panorama of views from City Park. George wrote: "The panorama of city, farm, country, river and mountain will be unsurpassed." ${ }^{23}$ An impressive site, these men believed, could launch Portland ahead of its rivals.

${ }^{22}$ Ibid

23 "The Only Scenic Site, Judge George Favors Having the Fair on High Ground" The Oregonian, May 3, 1902. 


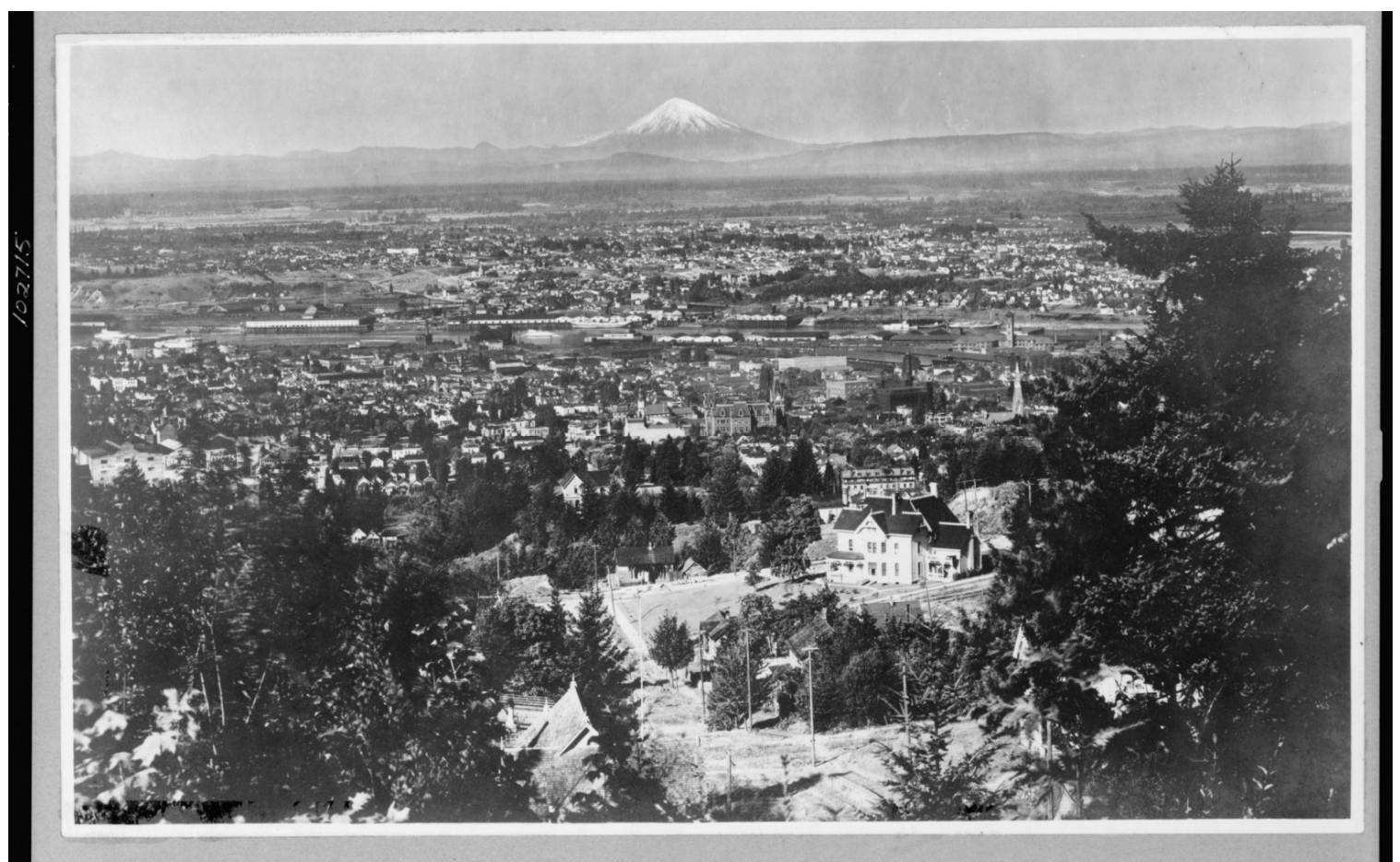

Figure 7. Photo from Portland Heights, 1903.

As this image shows, Portlanders were taking advantage of the impressive West Hills view by building mansions on the hills. [Courtesy of Library of Congress. Taken from Vintage Portland web site entry for January 27, 2012, entitled "Portland Heights Panorama, 1903]

Judge George was not alone in his grandiose dreams of renown a World's Fair could bring to the city. Oregonian editor Harvey Scott's editorial promised that, should City Park be chosen, and a system of boulevards established in conjunction with the Fair, Portland would be the envy of Eastern cities. Scott appears to have favored development of the West Hills_-but development of a certain class. He wrote: "Many people have expressed themselves in favor of the City Park. The proposal to open up a panorama of scenery by a system of boulevards on the heights back of Portland has been received with strong expressions of approval. Everybody admits that the prospect from the park is 
peerless." 24 The "heights back of Portland" encompassed the Poor Farm, Portland Heights and the neighborhoods that would come to be known as Arlington Heights, the Southwest Hills, Hillside, Kings Heights and Healy Heights.

The conversation around City Park for use as a fairground belies a changing perspective of the entire West Hills area. No longer a remote, if scenic, hinterland, local now believed the scenic views afforded could be used in Portland's ambition to cement its reputation as an up and coming city. Many leading citizens now felt the West Hills ridge, including the Poor Farm land, was highly valuable and underutilized.

24 “To Name Fair Site,” Oregonian, April 28, 1902. 


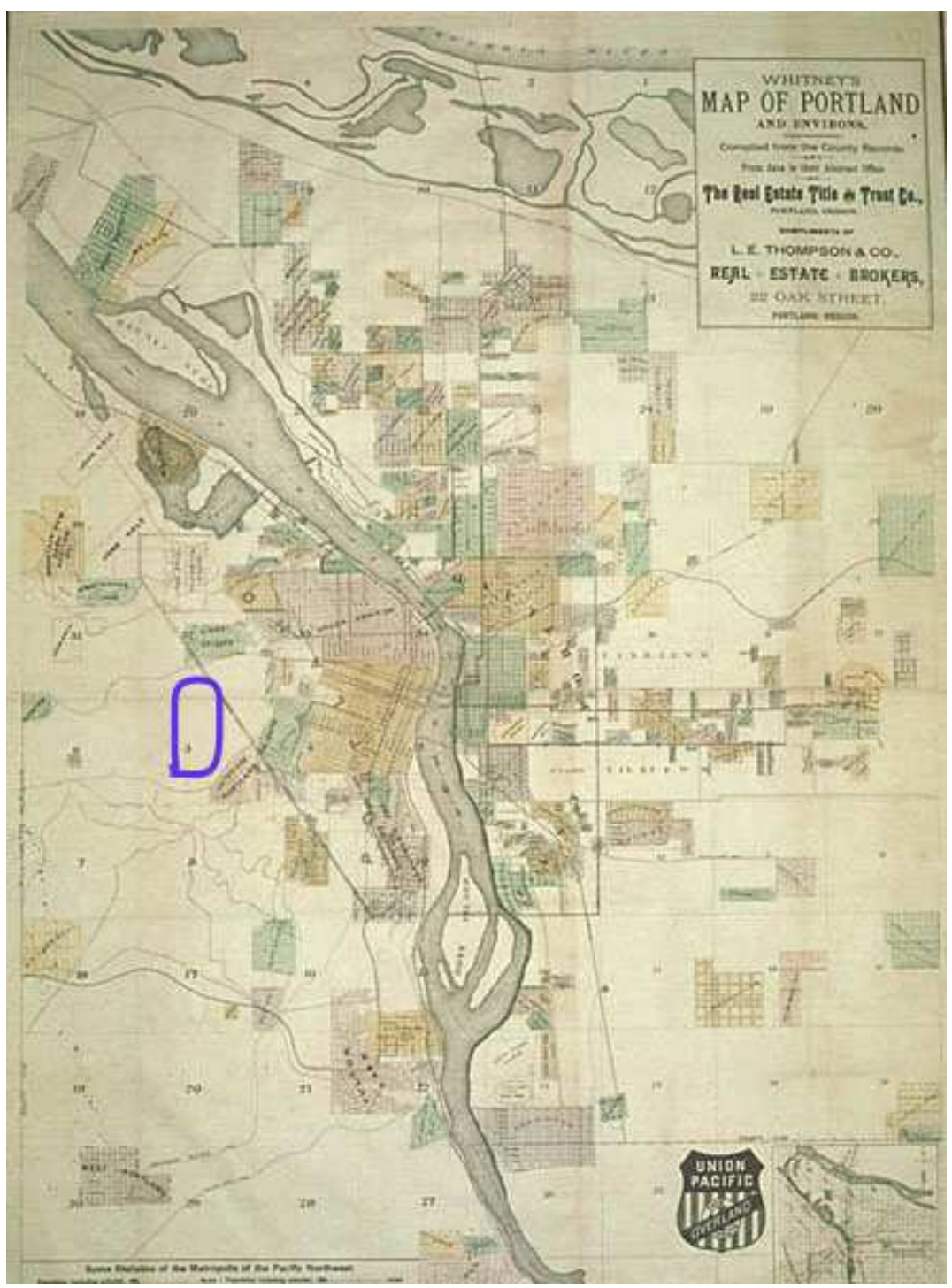

Figure 8. Real Estate Development Map of Portland, 1889

This map shows the real estate additions in existence or under construction in 1889 . The purple box, drawn by the author, indicates the approximate area of the Poor Farm, which is not indicated on the original map. Real estate and title companies often did not include the Poor Farm on their maps, perhaps because the land was not for sale, or perhaps because they did not want to advertise its presence to potential investors. This map indicates that entering the final decade of the nineteenth century, housing development were inching towards the Poor Farm. [Courtesy of Portland Bureau of Transportation website]

When the Lewis and Clark Exposition commission advertised for bids from land owners, 
they asked owners to include a description of how the land could be turned into a public park after the Fair, as well as a description of streetcar service, water supply, irrigation, and other advantages. ${ }^{25}$ Ultimately the City Park location fell through when streetcar lines refused to make necessary additions - a streetcar line already ran to the park, but fairgoers would need additional lines to transport them around the hilly grounds. ${ }^{26}$ Further, the nearness of the Poor Farm may have played a role in the unlikely decision to hold the Lewis and Clark World's Fair at Guild's Lake, rather than City Park. This choice may actually have allowed the Poor Farm to cling on to its West Hills location for a few more years.

In many ways, the Fair was a great success. The Heppner Gazette wrote that it "ended in a burst of glory" and "its influences for the betterment of a new country will live on forever." Furthermore, the gazette continued, whether financial, commercial or artistic: "Look at the Portland Exposition from any standpoint you will, and all you see is success." ${ }^{27}$ Mayor Harry Lane called a half day holiday on the last day of the fair, presumably so Portlanders might attend the closing ceremonies. Lane declared that the fair had provided "untold benefit to the city" by alerting the world of Portland's "beauty, delightful summer climate and true merits and worth as a business center." 28 The fair precipitated a seven-year boom for the city. Bankers, brokers and the Board of trade had pushed for the Exposition, and the planning process brought together the cadre of

${ }^{25}$ Carl Abbott, Portland (1983): 40.

${ }^{26}$ Abbott, Portland (1983): 41. Colonel Hawkins, however, did not accept this argument. He reportedly felt adequate transportation involving streetcars and other vehicles could be arranged.

27 "Big Fair Thing of Past," Heppner Gazette, October 19, 1905. Heppner, Oregon.

28 "Last Day of Fair a Half Holiday," Oregon Journal, October 13, 1905. 
businessmen who would guide Portland's land use for the next two decades. ${ }^{29}$

But if Portlanders wanted to demonstrate their superiority to other cities and live up to the Chamber of Commerce's "Prosperous Portland" image, ${ }^{30}$ they could not have the County Hospital and Poor Farm on display. Portland businessmen and developers struggled with how to promote their city as a leader of commerce, industry and civilization, with a relic of centuries past, and highly visible symbol of poverty, in their midst. As housing developments crept up over the west hills in the years following the fair, businessmen and politicians increasingly could not keep the Poor Farm out of sight, or mind.

\section{A "City of Homes"}

Much of the Fair's exhibits and programming reflected hopes for the future as much as reality of the present. For the Multnomah County Poor Farm, the particular aspirations that proved most relevant were those of real estate developers. In the years following the Fair, the city would experience an unprecedented building frenzy. As highend residential neighborhoods closed in on the Poor Farm from all directions, the Farm and its impoverished, tubercular residents seemed increasingly out of place.

Development of the West Hills residential neighborhoods began prior to the Fair, but accelerated afterward. Portland Heights was one of the city's older neighborhoods, but its inaccessibility prevented it from full scale development until the opening first of

${ }^{29}$ Carl Abbott. Portland: Planning (1983): 33. For detailed information on the financial impact of the Fair, see "Portland Booster and the Great Exposition," in Carl Abbott, Portland (1983): 33-48 and Carl Abbott's The Great Extravaganza (2004).

30 Though the July 1904 Chamber of Commerce bulletin claimed Portland had the nickname "Prosperous Portland," it does not appear in literature from that time period nearly as frequently as "city of roses." It seems likely that the Chamber was hoping to make the nickname catch on. 
the cable car and then the streetcar. Prior to the 1890 opening of the massive cable car trestle, the only route up to the flatter area of Portland Heights was dirt paths that became treacherous in the muddy winters. Wealthy families began building in the Heights even before the cable car, however, they primarily used the area for summer homes. ${ }^{31}$ With the cable car, living in Portland Heights full time and working downtown became possible.

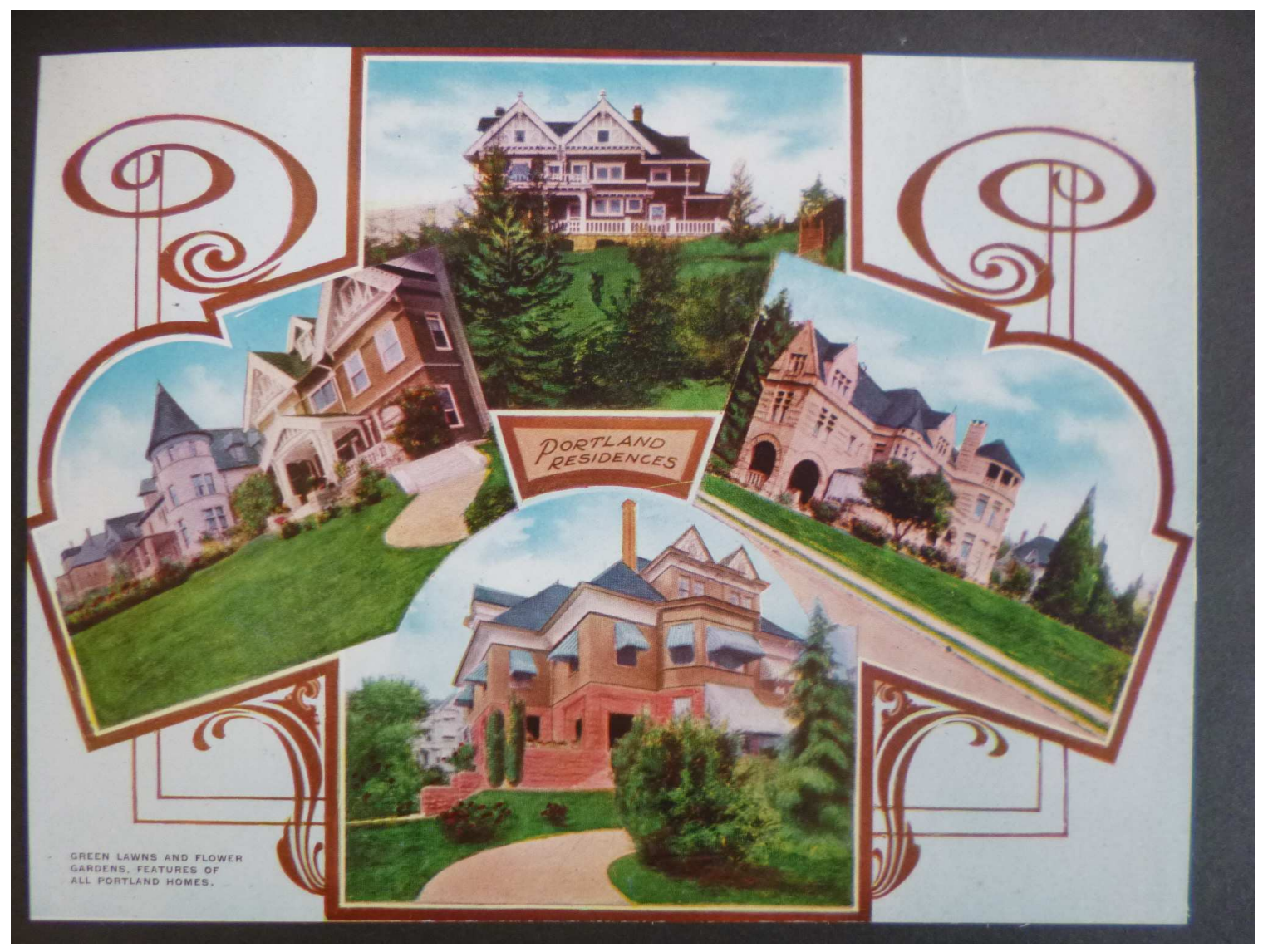

Figure 9. "Portland Residences"

A page in the 1907 promotional book, Portland, City of Roses. The drawings promote the image of a prosperous Portland, featuring only extravagant mansions. The caption reads: "Green lawns and flower gardens, features of all Portland homes." [Portland Archives and Records Center]

31 Jan Berhs, "Preserving History in Portland Heights," The Oregonian, September 26, 2010. Online. Accessed February 11, 2017. 


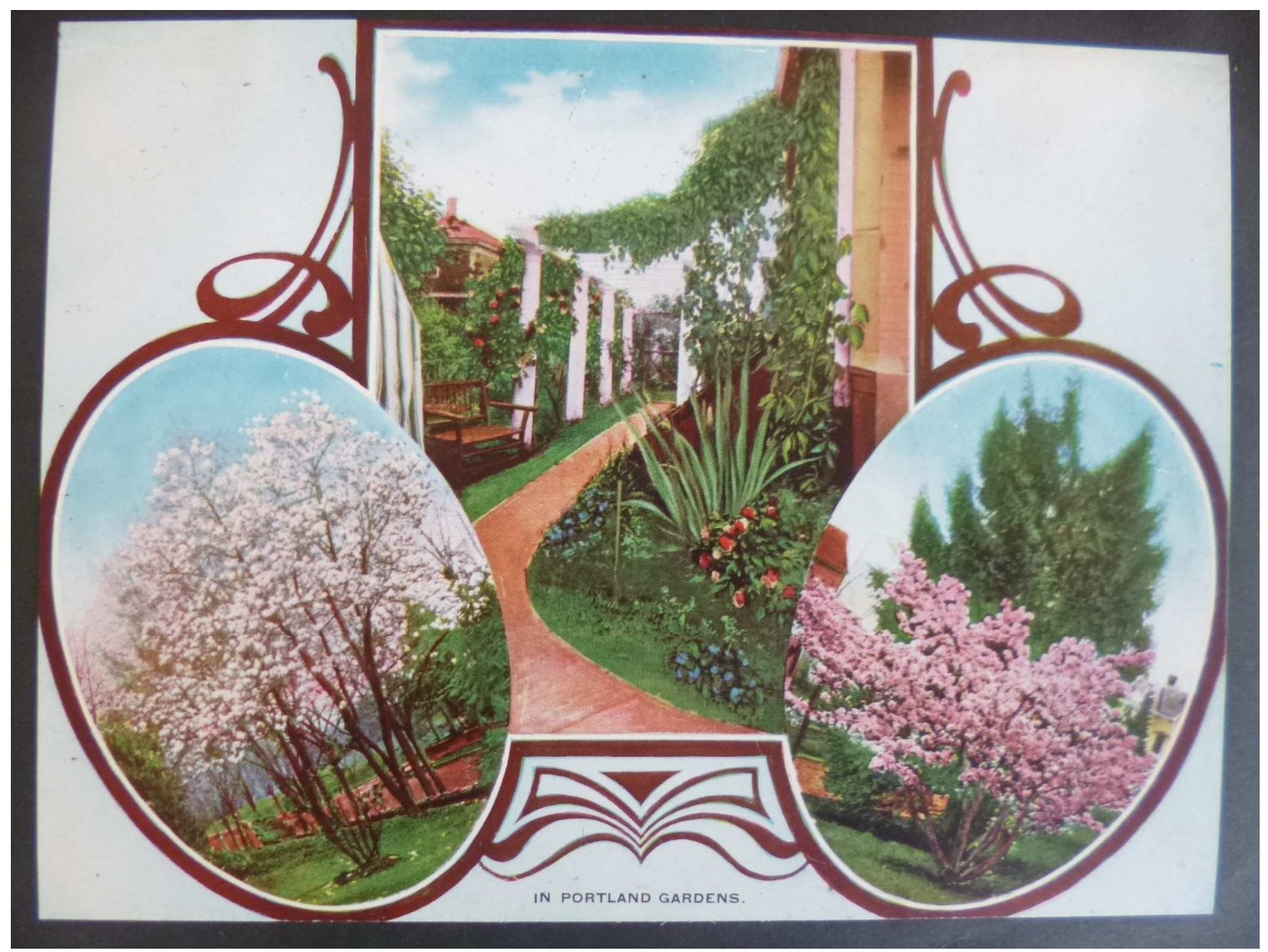

Figure 10. "In Portland Gardens"

A page from the 1907 promotional book, Portland, City of Roses. The images depict an image of Portland as healthy, verdant and affluent. Portland Archives and Records Center. 


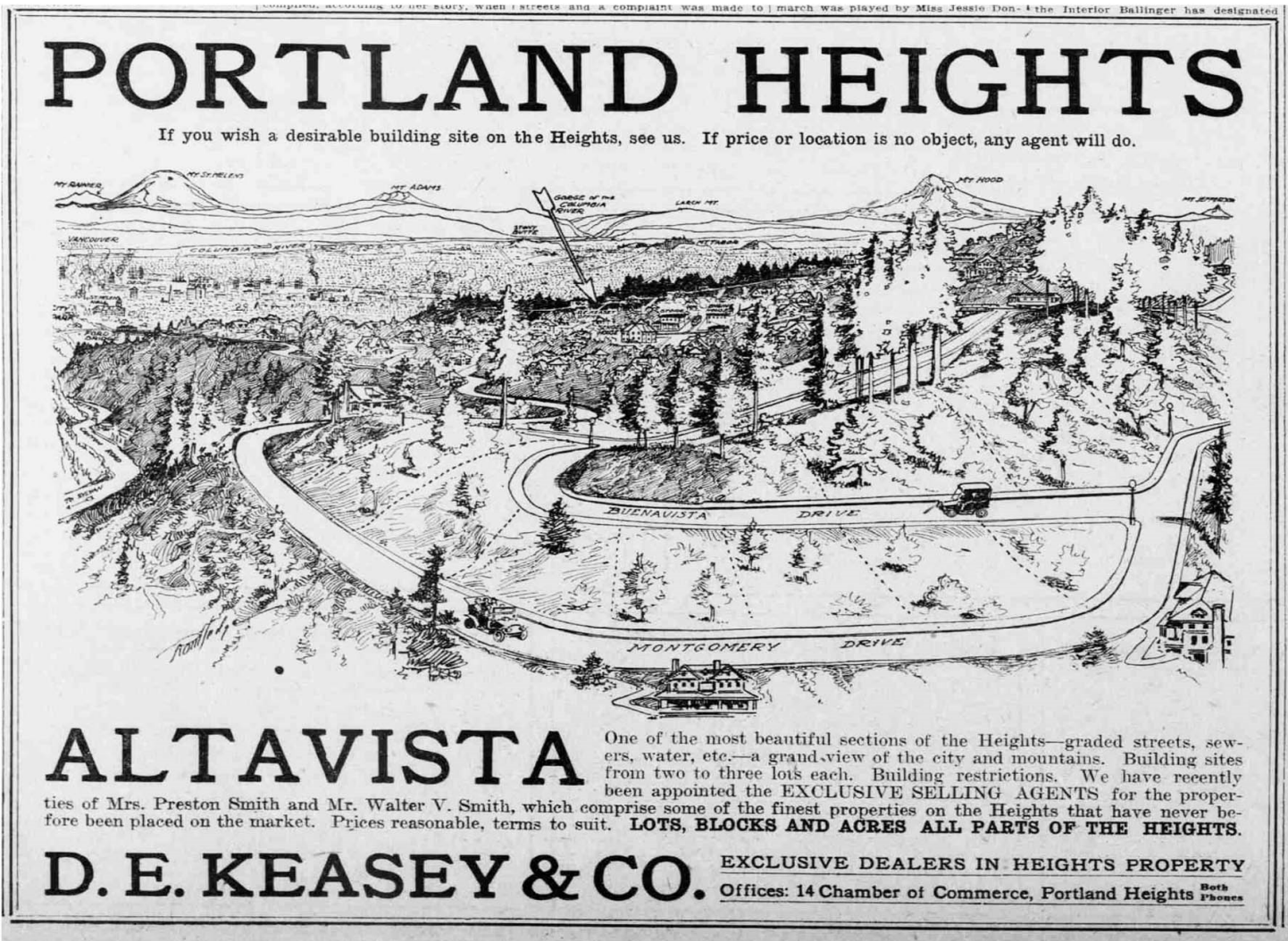

Figure 11. Portland Heights Advertisement, 1909.

Featured in The Oregonian. One of the neighborhood's main selling points was the view.

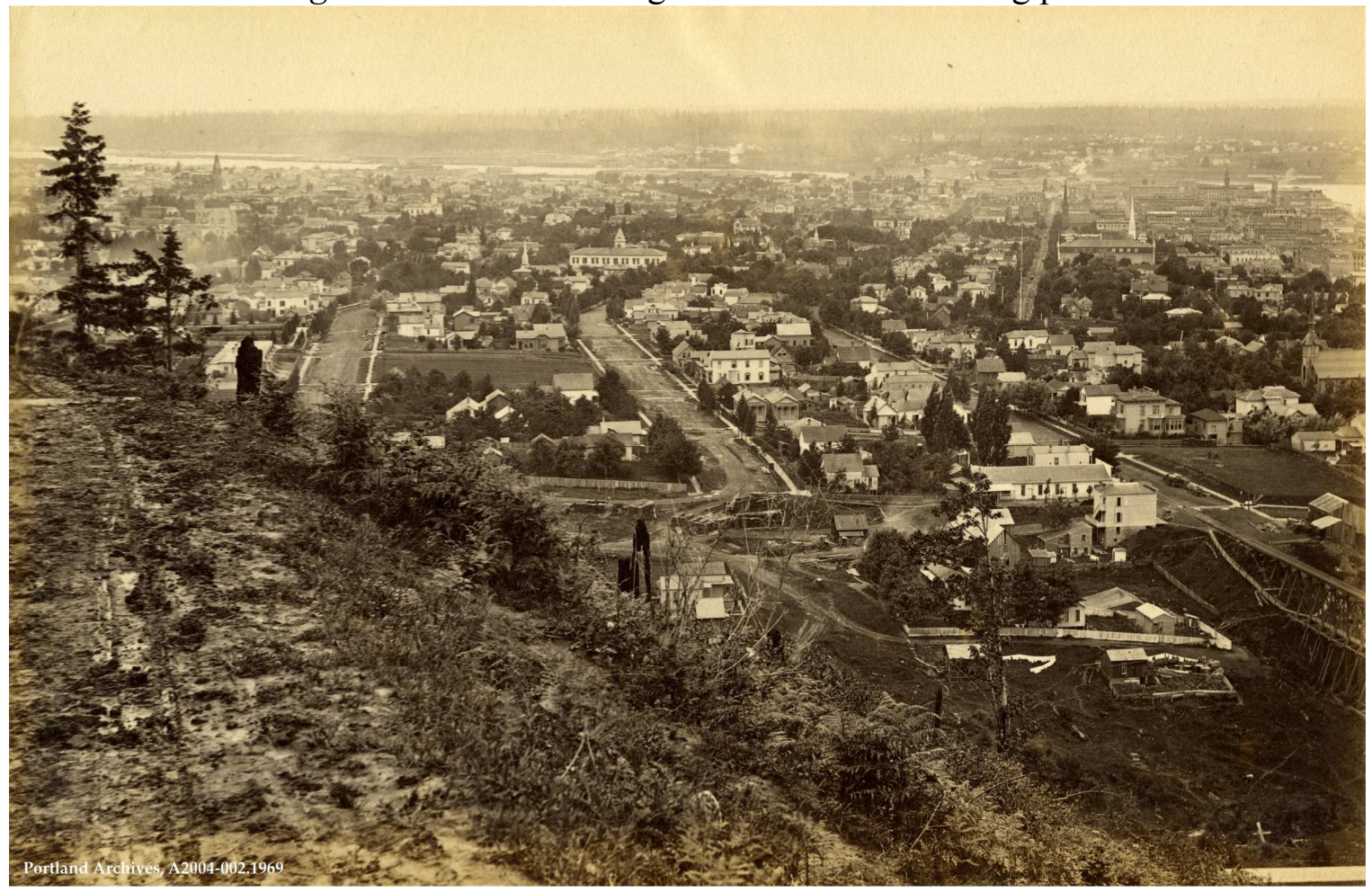


Figure 12. (previous page) View of Southwest Portland from Portland Heights, c. 1885. Visible are the old Portland high school, the Ladd Carriage House, and the areas that are today Pioneer Courthouse Square and Duniway Park. The muddy hillsides were difficult to traverse by carriage. [City of Portland (OR) Archives, A2004-002.1969]

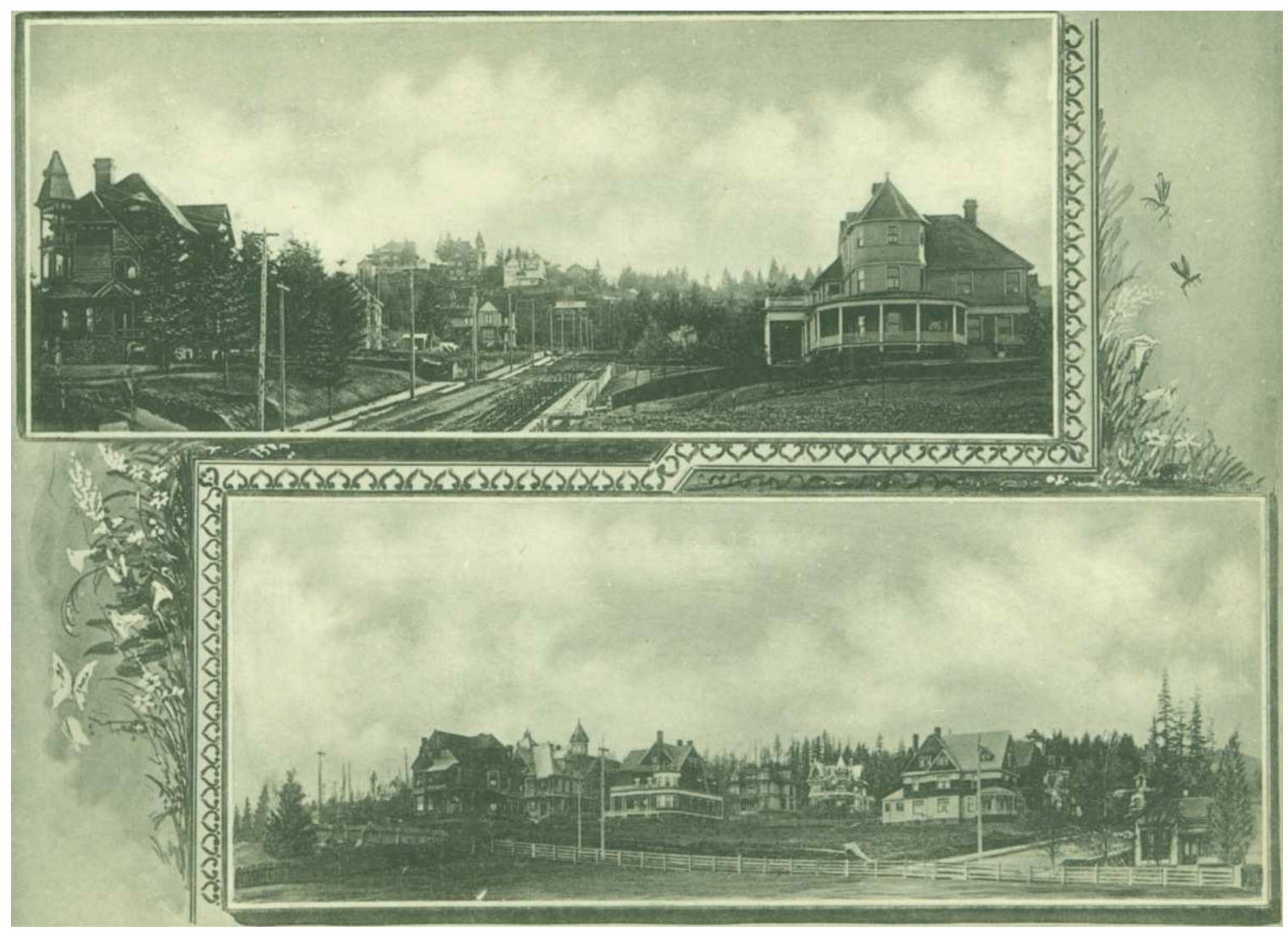

Figure 13. Group of Residences on Portland Heights c. 1892. Examples of some of the stately homes wealthy Portlanders built on the hills in the late nineteenth century.[City of Portland (OR) Archives, A2004-002.2565.]

An even bigger turning point in the development of the West Hills, and the demise of Multnomah County Poor Farm, came in 1904 when the Portland Railway Company opened the Portland Heights electric streetcar line, which ran along Vista Avenue and extended to Council Crest, the city's highest point. With this expansion of the electric streetcar along some of the city's highest ridges, formerly inaccessible neighborhoods were suddenly in reach—but how they should be developed remained an 
open question. Public parks, recreation grounds, and residential neighborhoods were all possibilities. But in early 1900s Portland, as in cities around the country, rapid population growth created a pressing need for housing. ${ }^{32}$

When the Portland Heights streetcar loop opened in 1904, if offered "the finest view of Portland and the surrounding country [which is] obtained from our heights to the southwest of the city." ${ }^{33}$ The line began at Union Station, ran into the heart of downtown and then climbed a hill to City Park. From there, the Portland Heights Loop went north, over the Jefferson Street viaduct, to Council Crest. ${ }^{34}$ From the Crest, a visitor could take in "the beauty for which [Portland] is justly noted" and gain "a knowledge of the sublimity of the panorama which Joaquin Miller, Thomas Nast, Charles Warren Stoddard, Joseph Cooke and other famous personages have eulogized." ${ }^{35}$ The streetcar line would open up the West Hills for development, and serve a scenic, recreational purpose too.

The new infrastructure brought passengers, who were part of the city's burgeoning tourist economy, and the poverty and disease of the poor farm into close proximity. So close, in fact, was the Poor Farm to the City Park that in 1909, a Poor Farm resident wandered away and his body was found close to the park grounds. According to the Multnomah County Hospital and Poor Farm ledger, the 29-year-old William Hawkins was admitted to the Poor Farm hospital on October 24, 1908. The Wisconsin native

\footnotetext{
32 “Portland's Cable Cars," Trimet web site. Accessed February 5, 2017. https://rimet.org/history/cablehist.htm

33 "New Portland Heights Loop," Chamber of Commerce Bulletin, July 1904. Poet Charles Warren Stoddard wrote in Over the Rocky Mountains to Alaska that a week's travel up the Columbia river was worth the reward of "one glimpse of; and at last, Portland, the prettiest of Pacific cities."

${ }^{34}$ which was replaced by the Vista Bridge two decades later.

35 "New Portland Heights Loop," Chamber of Commerce Bulletin, July 1904.
} 
suffered from "epileptic fits." He had been in Oregon for three years, and previously lived in Minnesota. Hawkins spent several weeks in the Poor Farm Hospital, during which time he took walks in the surrounding area. On December 7, 1908, he went for a walk and never returned. His body was found three days later "around back of" City Park. $^{36}$

Events like these likely contributed to the opinions expressed in the March 19, 1909 Oregonian editorial, "Move the Poor Farm." In this piece, the editor argued that the Poor Farm land was unsuited for its purpose because it was too large, too hilly, too wooded, and too close to the rest of the city. The Oregonian argued that "many men come to poverty and the general decrepitude that lands them in the poorhouse, relatively early in life, through dissipation.. ${ }^{37}$ After receiving rest and recuperation at the Poor Farm, they "take the short walk over the hills to the city, where drink and its associations beckon them, and away they go, to return in due time with pauper commitment papers, again to be fed and patched up." The editorial's tone was one of blame and suspicion; these men brought misfortune on themselves through their intemperance. In addition, the author described these Poor Farm residents as a burden; the men had no interest in improving their lives but were content to careen from debauch to restoration at the county's expense. While the editorial did not say that such men should be denied aid, it did state that moving the farm farther away from the city would decrease recidivism due

${ }^{36}$ Letter from EJ Carr to Mayor Harry Lane, April 17, 1909. Portland Archives and Records Center. A letter from the County Clerk, EJ Carr, to Mayor Harry Lane, dated April 17, 1909, described Hawkins' habit of going for walks. It noted that the County Farm Superintendent assumed Hawkins had left without notice, as patients often did. The letter described the site where Hawkins' body was found "about a mile from the Hospital." A police report dated April 2, 1909 and signed by Police Captain Charles Baty stated that his body was found December 12, 1908 "back of City Park, where from he died of exposure."

37 "Move the Poor Farm" The Oregonian, March 19, 1909. 
to drinking. Perhaps most importantly, the paper argued, "The present poor farm is a tract of land too valuable to be used or held for that purpose." Indeed, by 1909 the property values of land in Portland's West Hills had increased dramatically, and the business interests represented in The Oregonian believed such valuable land should be freed up for growth and development.

Portland's most famous residence, what would be called the Pittock Mansion, was a product of this growth and development. In 1909, the same year The Oregonian published the editorial advocating for the Poor Farm's relocation, that newspaper's publisher, Henry Pittock, broke ground on a palatial home in the Hillside/Kings Heights neighborhood. The Pittock Mansion was built on 46 acres of land above West Burnside Street, directly across from the land owned by the Poor Farm and the King Realty Company. Today, Pittock Mansion stands across from the Arlington Heights neighborhood and the northern end of the Hoyt Arboretum. 


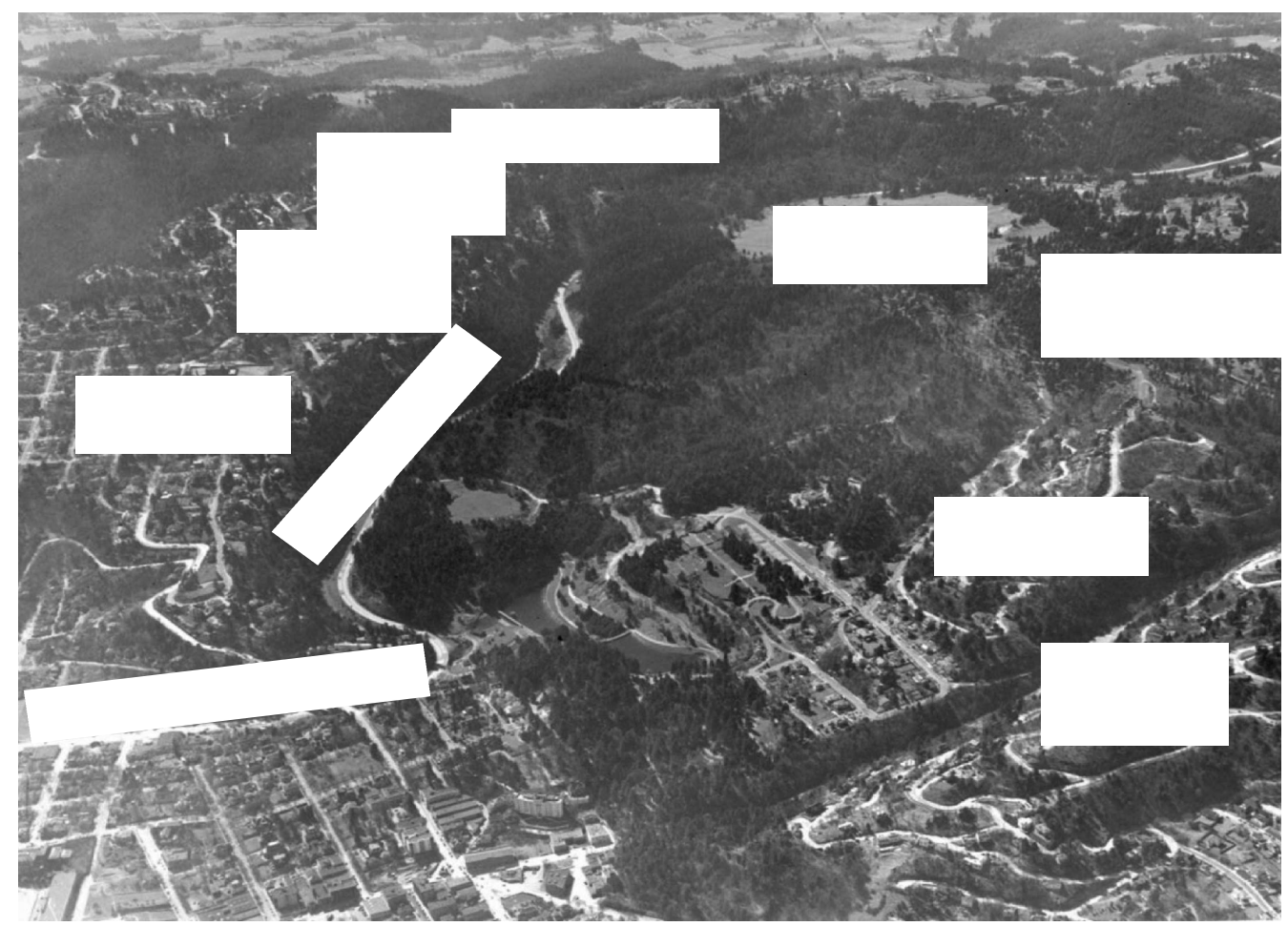

Figure 14. Aerial photo of Portland's West Hills in 1939.

Although this photo was taken in the decades after the scope of this thesis, it provides a helpful overview of the residential neighborhoods involved in the development of the West Hills. The Golf Links pictured is the area where most of the Poor Farm building were located, while the Hoyt Arboretum was Poor Farm land that was used primarily only for harvesting firewood. [City of Portland (OR) Archives, A2001-045.438. Text added by author]

Although it is impossible to say with certainty exactly which elements of the Poor Farm were visible from which vantage points, it seems likely that men such as Henry Pittock, B. M. Lombard, and other land owners surveying the hilltops encircling the Poor Farm, could have seen the farm land with its county hospital, pigs, cows, tuberculosis ward, and pest house. ${ }^{38}$ Although most of this land today is heavily wooded, in the early

${ }^{38}$ Based on my analysis of land maps, as well as visits to the Pittock Mansion, I believe the northern end of the Poor Farm land was likely visible from Pittock Mansion, but not the buildings and main cluster of activity. I reached this conclusion largely based on the fact that the northern reaches--today's 
twentieth century much of the West Hills' forest had been logged ${ }^{39}$ Pictures from that time period show a much clearer hillside. Because most of the buildings at the Poor Farm were clustered near Canyon Road, on the southern end of the land, the buildings themselves were probably not visible from Pittock Mansion proper, though the northern end of the county land probably was. In addition, patches of the Poor Farm parcel were likely visible from newly-accessible, desirable locations in Portland Heights (elevation $625 \mathrm{ft}$ ), Council Crest (elevation 1070 feet), and Green Hills (elevation 900 feet). As these wealthy residential neighborhoods grew, their investors increasingly complained that the Poor Farm was not deserving of the land it occupied.

Residents of nearby neighborhoods voiced concern about the character of their neighbors. From the west, property owners in Sylvan and unincorporated western Multnomah County agitated for removal of the Poor Farm and development of the land. The Oregonian reported in April1909 that Sylvan Committee members were dissatisfied with the United Railway Company, which had yet to deliver on a promise to build a streetcar line into the Mt. Calvary area, about a mile west of the Poor Farm. A resident of Sylvan, Mr. O'Bryan, reportedly said: "We want the county to move the Poor Farm away from the Canyon Road as soon as practicable, and we want the City of Portland to keep away from that road with its pest house. ${ }^{, 40} \mathrm{With}$ the streetcar line, O'Bryan said, speaking for property owners and residents of western Multnomah County, Mt. Calvary

Hoyt Aboretum--are roughly 200 feet higher than the southern portion of the land, just off of Canyon Road (Highway 26).

${ }^{39}$ Carl Abbott, "The 1905 Lewis \& Clark Exposition." Lecture at Architectural Heritage Center, Portland, Oregon, November 2016.

40 "Want Road Built and Promises Kept," The Oregonian, April 13, 1909. The pest house will be discussed in greater depth in Chapter Four. 
would be one of the most desirable residential areas in the Portland vicinity. "The Canyon Road is ... the greatest attraction for the westward growth of Portland and it should not be encumbered by pest houses and poor farms." ${ }^{41}$ The vocal residents and property owners of Sylvan saw the Poor Farm as an impediment to their physical and economic growth.

In pushing for the streetcar to Mt. Calvary, residents hoped to join the growing numbers of streetcar suburbs around the city. In the years following the World's Fair, real estate development and land speculation reached unprecedented heights. Construction soared on both sides of the river. On the East Side, Piedmont, Irvington, Alameda and Laurelhurst beckoned with promises of "high class homes" and "beautiful residence $\operatorname{park}[\mathrm{s}] . " 42$ On the West Side, the West Hills neighborhoods of Willamette Heights, Portland Heights, and Westover Terrace saw new development.

Unlike other World's Fairs, the Lewis and Clark Exposition did not have a lasting physical impact on the immediate surroundings. That is, it left no park or monument. The Forestry building stood as an impressive reminder until it burned down in the 1960s. Many of the Fair promoters had hoped the fair location could be transformed to a permanent park, and a park at the Guild's Lake site would have been in harmony with the Olmsted Plan. But a park in this location was not realized, and as soon as the fair closed, the land reverted back to its multiple owners. Guild's Lake disappeared within two decades. First, development of the West Hills, specifically, sluicing of the hillside to create the Westover Terrace residential development, began the process of filling the

\footnotetext{
41 "Want Road Built and Promises Kept," The Oregonian, April 13, 1909.

42 Advertisement for Alameda Park and Laurelhurst, Portland Chamber of Commerce Bulletin, February 1910, 61-63.
} 
lake. The creation of the New Willamette River channel and attachment of Swan Island to the East Bank of Portland in the 1920s provided the bulk of the material that filled the lake. $^{43}$

So while the Fair did not change the Portland skyline in the way of the St. Louis arch or the Seattle Space Needle, it indirectly influenced the flank of the West Hills by contributing to population growth and land speculation. Further, the Fair coalesced the men and the methods that would guide land-use planning for the next several decades ${ }^{44}$ In the last quarter of the nineteenth century, Portland business was dominated by the second generation of Portland settlers, who made and lost their fortunes with the growth of the city. Although many of the new leaders were funded by the previous generation's wealth, they brought a new sense of professionalism and systematic purpose to their work. Many of the same men who had served on the Fair Commission would go on to serve on the Planning Commission..$^{45}$ These same names would help steer Portland through its biggest boom years, and simultaneously suffocate the Poor Farm.

${ }^{43}$ Abbott, Portland (1984): 47; Kathy Tucker, "Guild's Lake," in Oregon Encyclopedia (updated June 19, 2017) https://oregonencyclopedia.org/; Carl Abbott, "Port of Portland," in Oregon Encyclopedia (updated October 6, 2017) https://oregonencyclopedia.org/.

${ }^{44}$ Abbott, Portland (1984): 47.

${ }^{45}$ Ibid 47-48. 


\section{Chapter Four: Paupers, Lepers, and the Pesthouse}

Wong Suey lived almost completely alone in an isolated shack separate from the other Poor Farm buildings. His only companion was a yellow canary, an anonymous donation from a Portland woman. Public Health officials had removed him to the Poor Farm after multiple complaints that a Chinese leper was living in the nearly-abandoned row of shanties along Tanner Creek, formerly occupied by Chinese gardeners who raised vegetables in the low-lying riparian grounds.

The County Physician was not convinced that Suey was, in fact, afflicted with leprosy. But after several visits with the man, he changed his mind. Public outcry against the man's presence in the central city was loud, but officials could not agree on what to do with him. County officials argued Suey's presence was a public health matter which the city should address, whereas the city argued it was a matter of indigence, for which the county was responsible.

Ultimately, local authorities removed him to the Poor Farm, where he lived alone with his bird in a dwelling constructed especially for him. In 1907, Wong Suey died there. ${ }^{1}$

1 "Problem of Chinese Leper Tackled by City Fathers" Oregonian, August 16, 1906; "Not a Leper but a Sick Old Man," Oregonian, August 17, 1906; "Lepers Shacks Burned," Oregonian, September 23, 1906; "Canary for Chinese Leper,” Oregonian, January 6, 1907; "Chinese Leper is Dead,” Oregonian, August 26, 1907. 


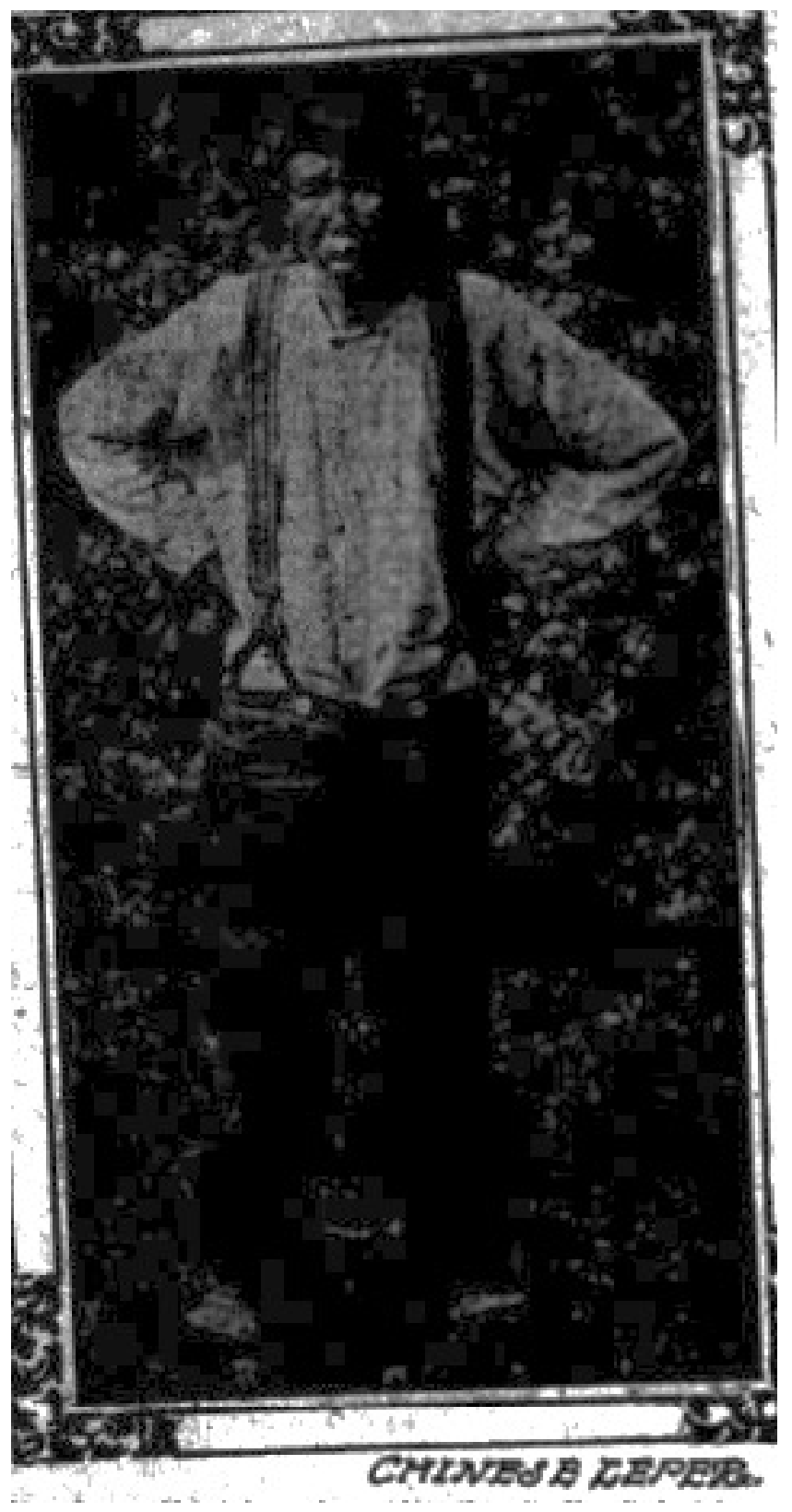

Figure 15. The Chinese Man Known as Wong Suey.

This picture, taken from the June 9, 1907 issue of The Oregon Journal, shows Wong Suey, presumably at the Poor Farm. This article refers to him by the name Sing Bong. 


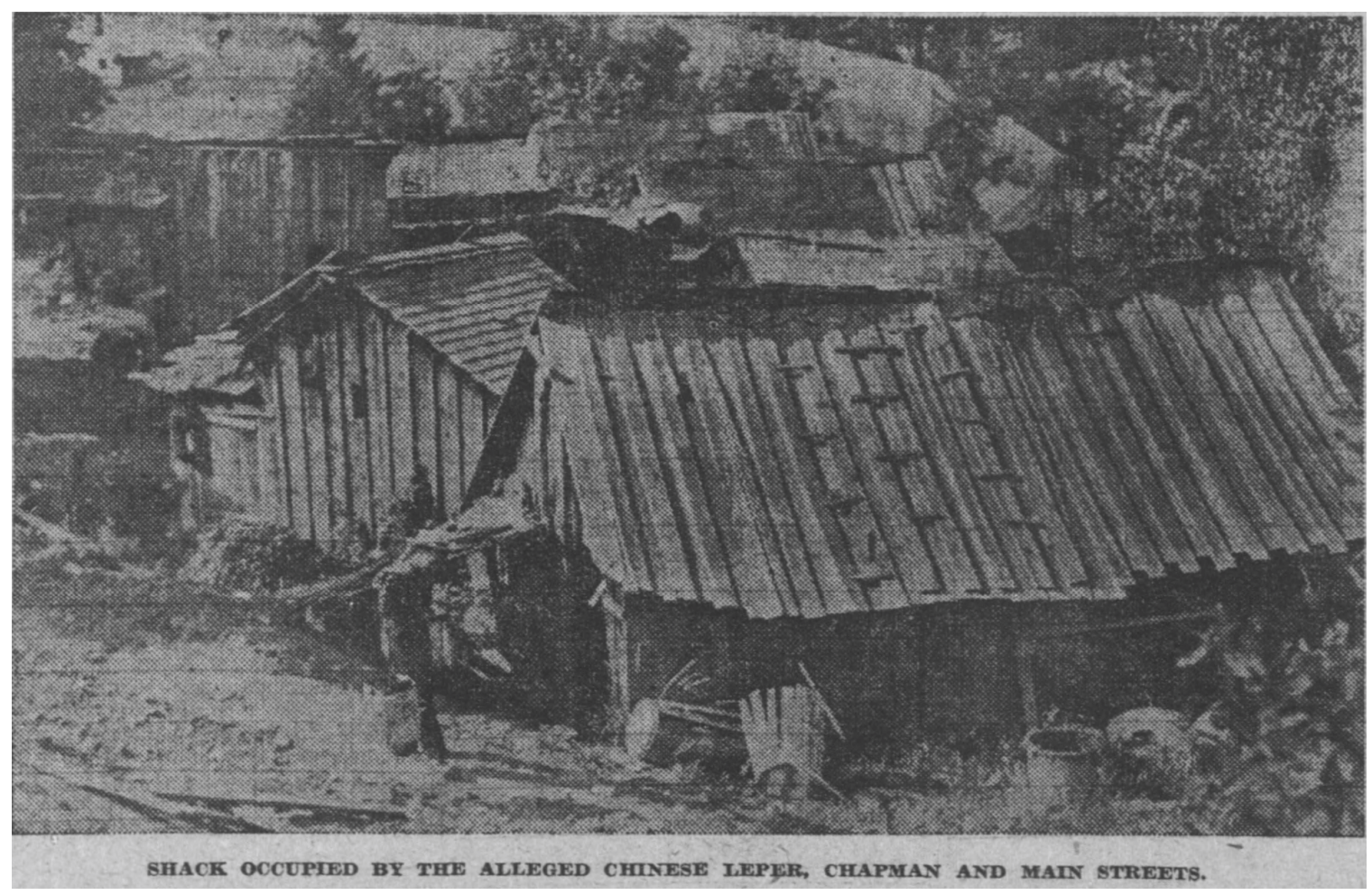

Figure 16. Wong Suey's Home

This photo, taken from the August 17, 1906 issue of The Oregonian, shows the low-lying area along Tanner Creek where Wong Suey, as this newspaper called him, lived. In the previous century, this area had been home to a community of Chinese vegetable gardeners. But the newspaper articles from 1906 stated that Wong Suey was the only remaining inhabitant of the area.

The City Beautiful movement was not the only Progressive Era reform that would put pressure on the Poor Farm; the advent of Public Health also had a profound effect on the relationship between the Poor Farm and the rest of the city. The movement to organize agencies and systematically tackle health issues meant more enforcement, more control by government apparatus, and a concerted effort to track people and populations. In addition, a widespread acceptance of the contagious nature of many diseases, including 
tuberculosis, rendered any institution harboring a large percentage of sick residents, such as the Poor Farm, even more unwelcome.

\section{Quarantines and the Pest House}

In the nineteenth century, government efforts in Oregon to enforce health ordinances primarily focused on controlling infectious diseases. Portland began organizing and enforcing laws related to health in the $1860 \mathrm{~s}$, but similar action on the state level was much slower. Whereas Portland established a Board of Health in 1873, Oregon did not create such a body until 1903 — and it was the 47th state to do so. ${ }^{2}$ The one exception to Oregon's reluctance to pass health legislation was the use of quarantine. The state's earliest effort to control the spread of disease, an action that might be considered proto-public health, came in the form of the Quarantine Act of 1873. In the 1870s and 1880s, Portland was a thriving port city, and residents were familiar with the diseases sailors and ships carried. Poor Farm records show that most of the typhoid cases admitted from the 1880 s onward were sailors. ${ }^{3}$ The state Quarantine Act required ships passing through Astoria, at the mouth of the Columbia River, to undergo inspection for smallpox and other infectious diseases. Ships and crews were detained until cleared by a health inspector.

Public Health concerns in the nineteenth and early twentieth centuries often took on a racialized and xenophobic tone. In the late 1800s, this concern primarily focused on

\footnotetext{
${ }^{2}$ Brochure. Public Health in Oregon, Oregon Health and Science University Library, Archives Display, Portland, Oregon (Summer 2017).

${ }^{3}$ Multnomah County Hospital and Poor Farm Ledger, vol I. The record books that the Poor Farm and Hospital began keeping in 1900 included some backfilled entries for residents who were admitted during the previous century. At the time of writing, the author has not located cohesive records for the nineteenth century, though piecemeal records of admissions can be found scattered throughout the Journal of the Board of County Commissioners, located on microfilm at the Multnomah County Archives, and in the form of monthly reports of the Poor Farm sometimes printed in local newspapers.
} 
Chinese laborers, who American-born citizens often accused of being vectors for smallpox and leprosy. The discussion of Chinese immigrants and disease in newspapers and at the Board of Health included judgment of the living conditions in Chinatown, which contemporary accounts portrayed as a hotbed of prostitution, narcotics use and unsanitary living. American-born residents viewed Chinese immigrants with suspicion. In August 1868, for example, the mayor of Portland required a ship carrying Chinese laborers to land below the city, even though they had been cleared at Astoria. ${ }^{4}$

The Oregonian frequently reported on disease in other West Coast cities as wellespecially San Francisco. On May 2nd, 1876, the paper reported that all Chinese inmates of the San Francisco pest house- except the lepers—-had been kicked out because locals did not want their tax dollars supporting Chinese immigrants. The same month, in Antioch, California, angry residents set Chinatown ablaze. The arson occurred after several local boys contracted an undisclosed disease at a Chinese brothel. In response, (presumably non-Chinese) residents of the city descended on Chinatown and forced the inhabitants to leave on ship for San Francisco. One woman, who was "nearly gone with disease" started to sail for Stockton, California but somehow decided to return to Antioch. When some residents discovered that she was back in Antioch, the citizens were once again enraged and a fire broke out which the fire department reportedly did little to stop. The Oregonian noted that as a result of the fire, "Antioch is free from this degraded class." What happened to the residents of Chinatown or the sick woman was not reported. ${ }^{5}$

\footnotetext{
4 "The Circumlocution Office on Sanitary Matters," Oregonian, August 26, 1868.

5 "Pacific Coast News," Oregonian, May 3, 1876.
} 
Abigail Scott Duniway's New Northwest also had harsh words for sick Chinese in San Francisco. That newspaper reported in 1876 that of twelve Chinese lepers walking freely in the streets of San Francisco - a freedom of which the newspaper editors clearly disapproved — four were women "plying a nefarious business in Chinatown and endangering the health of the community." When the lepers were "disposed of," the paper continued, care would be taken not to allow more "similarly affected." ${ }^{\prime 6}$ On September 2, they began voyage to China on The Great Republic, but whether they survived the voyage is unknown. ${ }^{7}$ When San Francisco again sent a group of lepers back to China in 1880, the New Northwest editorialized that "people of the East who read this paragraph may awake to one of the dangers attendant on Chinese immigration." Duniway's words were prescient, as Congress passed the Chinese Exclusion Act in 1882. In the opinions presented in local Oregon newspapers, Chinese immigrants represented danger, both physical and moral.

Racism and fear of contagion combined to form a major news story in Portland in 1888 surrounding the fate of Chinese men living at the Poor Farm who were presumed to have leprosy. Newspaper articles of the time refer to them almost exclusively as "Chinese lepers," a term which relegates all twelve men to one underclass and foregrounds their nationality and health problems. The phrase belies the endemic racism and xenophobia of Portlanders at the time. The Oregonian printed a piece complaining about the high expense of maintaining these men at the facility and asserting that Portland should follow

\footnotetext{
6 "Recent Events," New Northwest, August 11, 1876.

7 “Chinese Lepers Sent Back Home," Oregonian, September 2, 1876.

8 General News, New Northwest, December 23, 1880.
} 
San Francisco's lead and send them back to China. ${ }^{9}$ In the Poor Farm report for August of the same year, the paper declared that "the county authorities are in favor of ridding the community of the Chinese lepers by sending them back to China." ${ }^{10}$ A January 12, 1888 letter to the editor, signed by J. C. McGrew, said that every grand jury for the last three years had recommended shipping the lepers to China, and asking why the commissioners had not yet done it. ${ }^{11}$ The Oregonian also ran a countering letter, signed by "The Countess," that called out the hypocrisy of Portland's elite, especially the women of organized charity associations, for turning a blind eye to the lepers and choosing to deal with more pleasant problems, like the orphans home. The Countess in effect condemned the idea of a worthy and unworthy charity case. She wrote that besides the lepers, other residents of the Poor Farm deserved a kind word and compassion, and she chastised the ladies of charitable organizations for choosing to visit and promote charities they found easier to confront. ${ }^{12}$ She suggested that, since the county had arranged to have the men shipped back to China, the wealthy of Portland ought to donate comfort items to make their voyage more tolerable. ${ }^{13}$ The Oregonian editor responded by saying that "Countess" had a "woman's heart" and therefore a right to feel compassion for the Chinese lepers. The editor then questioned the ethics of society's prolonging the

${ }^{9}$ Untitled, Oregonian, 7-14-1887

10 "The Poor Farm-Report of the Superintendent," Oregonian, September 8, 1887.

${ }^{11}$ Letter to the editor, Oregonian, January 12, 1888.

${ }^{12}$ Though the Countess did not explain why the Poor Farm should be a more difficult place to visit than the orphanage, jail or asylum, we can speculate that the sick and aged demographics of the Poor Farm played a role. In addition, many respectable ladies of the time believed that people landed in the Poor Farm due to bad choices or an immoral lifestyle. Perhaps these beliefs colored charitable organizations' perception of the Poor Farm inmates and rendered them less worthy of aid in the eyes of potential donors.

13 "ship back" is the dehumanizing phrase newspapers of the day used when talking about ridding the county of the lepers. 
life of a leper, rather than shooting him humanely like a horse. ${ }^{14}$ The editors found little to no value in the lives of Chinese lepers.

Perhaps not everyone shared the view of the Oregonian editor, but it seems support was strong for getting rid of the lepers. The sick men reportedly asked for fifty dollars each to assist them when they landed in China. The Oregonian reported that the Portland Chinese community wanted to be rid of them and would not have trouble raising the funds. ${ }^{15}$ They eventually settled for fifteen dollars each. ${ }^{16}$ When the men were rounded up from the Poor Farm, "The unfortunates and their belongings filled two large wagons." ${ }^{17}$ After several years of living as pariahs, they were "shipped on the Bark Kitty” for China.

Local government's increasing drive to intervene in the name of public health was disproportionately, but not exclusively, focused on Chinese. The same year that Portland's Chinese lepers sailed for China, an East Portland man named Jacob Anderson refused to leave his home or go into isolation while experiencing a smallpox outbreak. His neighbors reported him to city authorities. The Oregonian stated that "if he will persist in going about spreading the contagion, his removal to a pest house becomes a necessity and he should be taken there and compelled to remain until the danger of

14 “The Chinese Lepers," Oregonian, May 17, 1888.

15 "Want a bonus for leaving," Oregonian, July 26, 1888. AMe

16 "In and about Portland," Oregonian, September 6, 1888. Nearly two decades later, in 1906, The Oregon Journal mentioned the fate of these men. At that time, the city was questioning what to do with an individual Chinese leper, Wong Suey (or Sing Bong). In describing how the city handled the situation in 1888, The Oregon Journal said that the thirteen lepers (some reports say fourteen) were confined to a stockade on the Poor Farm land, as far away from the other buildings as possible. They would occasionally walk downtown and "levy tribute on their countrymen," and when they did so, the police struggled to make them return to their confinement. On their sad fate, the paper stated that some of the men died at sea and that "it was always believed here that the others were killed soon after they left the British colony and before they reached Canton." ("Chief Will Help Decide Chinese Leper Question," The Oregon Journal, August 16, 1906)

17 “The Lepers are About to Go," Oregonian, August 10, 1888. 
contracting the disease is passed." ${ }^{\prime 18}$ It is unclear whether Anderson was an immigrant or a native-born American. What is evident is that a significant portion of public opinion felt the government should intercede to control the man's movements.

\section{The Pest House}

White and American-born citizens, too, were subject to quarantine. Within the city limits, people with infectious diseases were often forced into isolation. In Portland, as elsewhere, early public health efforts mixed with criminal justice and exuded a penal air: in the city's early days, the power to enforce public health ordinances lay with the police. ${ }^{19}$ In his history of Oregon, Oregonian editor Harvey Scott noted that every policeman was also a health inspector, that the city physician had the authority to inspect all buildings, ships and trains, and that city council had "necessary power of quarantine. ${ }^{, 20}$ If someone was found to have a contagious disease, they might be sent to an isolation hospital, or "pest house."

Records indicate that a Portland pest house — the term commonly used in the nineteenth century for a quarantine or isolation hospital where people with infectious diseases would be kept, sometimes against their will—existed in the city as early as 1867 , though the nature and location of the building are not clear. ${ }^{21} \mathrm{~A}$ few years later, in 1873 ,

18 "Ought to be Suppressed," Oregonian, September 1, 1876.

${ }^{19}$ Oregon Health Authority, Public Health Division, “Administrative Overview," (November 2014) http://sos.oregon.gov/archives/Documents/recordsmgmt/sched/overview-health-public.pdf. In 1862, the city established a Committee on Health and Police, and passed an ordinance requiring doctors to report any cases of infectious disease to the committee. Thus a movement to coordinate public health enforcement among various authorities began in the mid-nineteenth century, though adherence to the ordinances was poor.

${ }^{20}$ Harvey Whitefield Scott, History of Portland, Oregon, (Portland: D. Mason, Co., 1890): 187.

21 "City," Oregonian, April 11, 1867. 
the city government charged Police Chief Lappeus with selecting a new site. That the chief of police would oversee the scouting and locating of the pest house underscored the connection between law enforcement and public health at the time. The County Commissioners offered a piece of the Poor Farm land, but Chief Lappeus determined that the cost of constructing a road to the parcel was prohibitive. ${ }^{22}$ Instead, he chose a patch of land North of the city near Guild's Lake, and the pest house remained there until $1887 .^{23}$ That year, the Portland Water Company, who had leased the Guild's Lake pest house location to the city, put the land up for sale and asked the city to relocate the quarantine hospital. ${ }^{24}$ Two years later, the pest house was operating on the Poor Farm property. ${ }^{25}$ Throughout its history, Portland's pest house was an unstable, and often poorlymaintained, institution. After a large smallpox outbreak in 1891, the first incarnation of the Poor Farm pest house fell into disrepair and officials ordered it burned in $1896 .^{26}$ After several years with no formal isolation hospital, the City Council once again debated whether to rebuild and, if so, where. The Committee for Health and Police negotiated with the county commissioners to find another place on the Poor Farm land for a city pest house. ${ }^{27}$ Finding a place for the pest house was a thankless task, and one that would prove increasingly difficult as the city grew and potential neighbors everywhere objected to infectious patients living nearby.

22 "City--Out to Locate," Oregonian, July 19, 1873.

23 "Site for Pest House," Oregonian, July 24, 1873.

24 "The City Council," Oregonian, October 6, 1887.

25 "Fierce Forest Fires," Oregonian, September 19, 1889.

${ }^{26}$ Burning pest houses was a common practice, as it was thought to be most effective way of neutralizing contagion.

27 "News In Brief--Need of a Pest House," Oregonian, March 3, 1899. 
In 1899 , the city constructed another pest house at the Poor Farm, but not without protest. Neighbor George P. Gray sued the city of Portland for constructing the facility north of 242 acres he owned in the Southwest Hills. The city had purchased property bordering his in April 1899, and in June and July, moved smallpox patients and people suffering from other contagious diseases, to this site. Gray argued that prevailing winds, as well as the drainage, ran from the pest house to his land, rendering it unsafe to live in and destroying its value. He sued the city for 2,500 dollars, but the case resulted in a nonsuit granted..$^{28}$

A decade later, another fire and another argument over rebuilding the pest house broke out. In March 1909, the second pest house at the Poor Farm burned to the ground. The Oregonian reported that a defective flue started the blaze. There was only one patient present at the time, and she was able to walk out, but three firefighters were exposed to smallpox. At that time, Portland Mayor Joseph Simon said the city planned to rebuild. ${ }^{29}$ But when the city sought a location to place the next incarnation of the Pest House, they could not find a welcoming neighbor.

The City Council and the Board of Health clashed over the location of the new structure. Dr. Wheeler, former Health Officer for the City, supported rebuilding on or near the site that had just burned down. Councilman Baker accused Dr. Wheeler of threatening to place the reconstructed pest house on Baker's property if he did not go along with Dr. Wheeler's proposition. The Oregonian also printed Dr. Wheeler's rebuttal,

\footnotetext{
28 “Objects to Pest House," Oregonian, July 16, 1899; Portland (Or.). Office of the Mayor, "Mayor's Message and Municipal Reports of the City of Portland, Oregon 1900" (1900). Portland City Archives. Paper 22. http://pdxscholar.library.pdx.edu/oscdl_cityarchives/22.

29 “Fire Destroys Pesthouse," Oregonian, March 24, 1909.
} 
wherein he denied the allegations. According to the newspaper, no one wanted the pest house located nearby. ${ }^{30}$

Dr. Wheeler had recommended purchase of a tract of land to build a new pest house at a different location, still on Canyon Road on the Poor Farm land. The Health Board requested the city council appropriate funds for it right away, and Mayor Simon agreed, saying the city needed a detention hospital as soon as possible. Councilman Baker tried to block this appropriation, and another to rebuild on the site of the pest house that burned down from the defective flue. Wheeler, for his part, accused Baker of blocking any proposition that would place the Pest House relatively close to his own property in Portland Heights. While Baker admitted that owning property in the vicinity of both proposed Pest House locations affected his opinion, he contended that public outcry against rebuilding near Portland Heights overshadowed his own opposition. The City Council had received many letters from residents of the adjoining neighborhoods protesting the Pest House. Councilman Baker reportedly argued that "the detention hospital should be located outside of the city limits, and that it is a detriment to any community and forces down the price of property, thus working a hardship on a large number of people." ${ }^{31}$ Though it had always been true that the pest house brought down property values, opposition grew especially strong during the conversation around rebuilding after the 1909 fire. The reason for this intensified opposition likely came from the fact that Portland Heights and the Southwest Hills had experienced major population growth and development over the previous decade and wealthier neighborhoods across

\footnotetext{
30 "Pesthouse Cause of Hot Squabble," Oregonian, November 9, 1909

31 Ibid.
} 
the city were beginning to organize associations to advocate for their interests. Perhaps the Portland Heights and other Southwest Hills neighbors begrudgingly tolerated the existing Pest House before it burned down, but when the opportunity came to be rid of it, they mobilized.

Councilman Baker was correct that the Portland Heights residents strongly opposed rebuilding the pest house near their neighborhood. At a meeting of the Portland Heights Improvement Association, members voiced their displeasure, only to be rebuffed by Mayor Simon, who said the Poor Farm location was the best one presented. As an alternative, the Portland Heights Neighborhood Association proposed locating the pest house outside the city, at the new Poor Farm site in Troutdale, which the county had already purchased. For the residents of the Southwest Hills, the county's intent to relocate the Poor Farm presented an opportunity to get rid of the smallpox and leprosy patients who had lived too close for comfort for decades.

\section{Controlling the Movements of Diseases and People}

By the opening decade of the twentieth century, government bodies and regulatory officials had more tools at their disposal than hauling people off to the pest house. Isolation was still an important component of public health, but prevention and hygienic education were also increasingly utilized. Further, new methods of tracking people and diseases empowered the government to control residents' bodies and movements. 
As government devoted more resources to public health, newspapers increasingly reported on contagious illness, its origins and vectors. The Oregonian began running a “Contagious Diseases” section in 1891, but this column initially focused on major outbreaks around the world and the country. In the early 1900s, however, the "Contagious Diseases" section began printing cases reported to health authorities, including names and addresses of the afflicted. ${ }^{32}$ Two incidents reported in May 1902 exemplified the increasing media and government attention to the spread of disease. In the first case, a man and a woman, who had been boarding at the Occidental Hotel on the corner of First and Morrison, were found to have smallpox and were taken to the pest house. Health officers believed the pair had tried to conceal their condition, and City Physician James Zan said the woman who ran the boardinghouse was ignorant of the situation. Around the same time, smallpox was reported at a boarding house on Second and Columbia. A family who had been lodging there became ill, and the physician who treated them misdiagnosed their sickness as chickenpox. The Oregonian chastised the physician for failing to report all infectious diseases, including suspected chickenpox. ${ }^{33}$

The smallpox outbreak at the Occidental Hotel and the boarding house touched on the major themes surrounding public health and disease management in the early twentieth century: an imperative for authorities to track - and, implicitly, to containcontagious diseases, the expectation that ordinary citizens and doctors would cooperate with the government authorities by reporting contagious diseases to them, and a focus on the lower class. The area where the smallpox was found, close to the waterfront in the old

\footnotetext{
32 “Contagious Diseases," Oregonian, April 12, 1902.

33 “Two More Smallpox Cases,” Oregonian, May 5, 1902.
} 
part of the city, was considered a raucous and uncivilized place, catering to vagrants, drifters, and seasonal laborers. The boarding houses and single room occupancy hotels concentrated in the area had a reputation for being filthy and servicing those groups that polite society considered a lower class of people. ${ }^{34}$ The urban environment was as unmanageable as the people.

Media coverage of smallpox cases continued throughout the decade, along with health officials' warnings that physicians and laypeople alike must comply with health ordinances. In 1901, City Physician Zan pushed for stronger quarantine laws for patients with smallpox, diphtheria, leprosy, bubonic plague, typhoid fever, and croup. If Dr. Zan had his way "Members of households in which these cases exist are forbidden to leave the house" and "Inmates of infected houses must not attend school, church or theater, nor shall they be permitted to ride in the streetcars until all danger of contagion is past." ${ }^{35}$ Over the next decade, the city's power of enforcement in the realm of public health would continue to grow.

The growing power of regulatory agencies and increasing intervention of government in people's lives and bodies meant officials paid closer attention to the operations of the Poor Farm. This increased scrutiny of Poor Farm management, and a

\footnotetext{
${ }^{34}$ Carl Abbott, Greater Portland: Urban Life and Landscape in the Pacific Northwest (Philadelphia: Univeristy of Pennsylvania press, 2001): 26. Abbott wrote that between 1900 and 1925, the Portland's waterfront was one of the largest skid row districts in the country, relative to the city's population. Alan Sykes, "Harold Farrow's Splendid Portland," Oregon Historical Quarterly 99 (1), 1998: 51-52. http://www.jstor.org.proxy.lib.pdx.edu/stable/20614869. Sykes described public inebriation in downtown Portland and the red light district along fourth avenue. The houses of prostitution were centered around Davis and Everett streets, but some stretched as far south as Salmon. Denise Alborn, "Crimping and Shanghaiing on the Columbia River," Oregon Historical Quarterly 93 (3): 262-291. Alborn examined the extralegal world of forced maritime labor in Portland from 1870-1900. Discussion of boarding houses along the waterfront was woven throughout.

35 "For the Public Health," Oregonian, March 31, 1901. America's Historical Newspapers.
} 
desire to make Portland institutions come into line with modern ideas about health and safety, would necessitate major changes at the Poor Farm.

\section{Tuberculosis Nails the Poor Farm Coffin}

In the early twentieth century, Portland's public health advocates joined the national fight to educate the public about tuberculosis. The great white plague was one of the deadliest diseases in in the country: in the century's opening decade, tuberculosis and pneumonia/influenza (these two were listed together) alternated between leading and second-leading cause of death in the United States. ${ }^{36}$ The challenge for public health workers was to change public perception of the disease, both among the general public and government officials.

A key figure in the movement to change Portlanders' understanding of tuberculosis was Esther Pohl Lovejoy. Lovejoy came to Portland in 1888. She graduated top of her class at University of Oregon medical school in $1894 .{ }^{37}$ Lovejoy, who was a practicing Portland physician and a member of the Board of Health, was appointed City Health Officer by her fellow board members in 1907. During her tenure, she continued to investigate cases of smallpox, diphtheria and other contagious diseases. She doggedly followed up reports of outbreak by inspecting the afflicted and their environs, and usually insisting on a greater level of fumigation than had previously been enforced. But even as Lovejoy continued the infectious disease work that her predecessors started, she also introduced a new, wildly ambitious goal: to eradicate tuberculosis.

36 "Leading Cause of Death 1900-1998," U.S. Center for Disease Control and Prevention. https://www.cdc.gov/nchs/data/dvs/lead1900_98.pdf

37 "Woman is Health Officer," Oregonian, July 12, 1908. 
Unlike smallpox, tuberculosis was endemic in the United States and as a result, convincing officials and lay people that prevention was a worthwhile endeavor proved challenging. Lovejoy noted in her 1907 report of the Board of Health: "It seems to be regarded by the people at large as a necessary evil.." ${ }^{38}$ Even members of the medical profession, she wrote, had criticized the Portland Board of Health for the prevention measures they had taken regarding public schools. Lovejoy continued, undeterred: "Tuberculosis is not only dangerous in itself, but a very active predisposing cause to other dangerous diseases; therefore all cases should be reported and at least a partial quarantine of the patient maintained." ${ }^{39}$ Lovejoy often felt stymied by her colleagues' unwillingness to enact reforms, both due to lack of funds and bureaucratic inertia.

Entrenched ideas about tuberculosis as a constitutional malady also complicated anti-TB efforts. For centuries, the medical profession and the general public had considered tuberculosis to be an affliction that affected individuals who were predisposed to it. Throughout the nineteenth century, many medical professionals held that climate and personal predisposition — a person's "constitution"-were the major determinants in the development of consumption. Although Robert Koch discovered the bacteria that causes tuberculosis in 1882, laypeople and doctors did not immediately accept these findings. Even when a critical mass of health professionals did accept that tuberculosis

\footnotetext{
${ }^{38}$ Health Department, "Office of the Board of Health of Portland, Annual Report, 1907" (1907), page 3. Public Health in Oregon: Discovering Historical Data. 227.

${ }^{39} \mathrm{Ibid}$, page 4. Interesting to note that as of the writing of this paper in 2017 , comorbidity of tuberculosis and HIV is extremely high throughout the world.
} 
was spread by a bacteria, many of them still felt the bacteria was endemic and little could be done to eradicate it. ${ }^{40}$

Despite the reluctance of government officials and of some members of the medical community, tuberculosis activists made significant progress in the early part of the century. The first tuberculosis sanitorium in the Northwest opened at Milwaukie Heights (today's Oak Grove) in January $1905 .{ }^{41}$ Around the same time, the County Hospital at the Poor Farm opened a separate TB ward, though historical records do not describe the nature of the isolation or the care received.

Medical professionals disagreed on the most effective treatment: some believed an isolated, devoted sanitorium was best for the patient and others advocated for the curative comfort of home. In a report to the 1907 meeting of the Oregon State Medical Association, the head of the new Milwaukie Heights Sanitorium, E.A. Pierce, argued that Oregon possessed a good climate for tuberculosis patients. Contrary to widespread opinion, he stated, the pure air and lack of dust helped patients recover, as evidenced by positive results he had seen the last two years at the sanitorium.

\footnotetext{
${ }^{40}$ As an example of how an understanding of TB progressed in Oregon, note the difference between a publication from 1870 and 1907. An article from 1870 entitled "Locality as Affecting Consumption" warned about the importance of locating buildings so as to avoid promoting tuberculosis. A person who is predisposed to it, the author wrote, should avoid damp ground and get plenty of sunlight. Medical Faculty, Willamette University, "The Oregon Medical \& Surgical Reporter, volume 1, number 4" (1870). Public Health in Oregon: Discovering Historical Data. 313. http://digitalcommons.ohsu.edu/public-health-data/313. Nearly four decades later, at the 1907 Meeting of the Oregon State Medical Association, state doctors acknowledged that the disease was contagious, but continued to debate whether climate mattered and whether sanitorium care or home care were more beneficial. "Transactions of the Thirty-Third Annual Meeting of the Oregon State Medical Association, 1907" (1907), Public Health in Oregon: Discovering Historical Data, http://digitalcommons.ohsu.edu/public-health-data/10

${ }^{41}$ Dr. E. A. Pierce, "Sanatorium Treatment of Tuberculosis in the Northwest," in House, William M.D., "Transactions of the Thirty-Third Annual Meeting of the Oregon State Medical Association, 1907" (1907), 48. Public Health in Oregon: Discovering Historical Data, http://digitalcommons.ohsu.edu/public-health-data/10
} 
At the meeting, other doctors' responses to Pierce's presentation varied widely. A doctor from Denver and another from Eugene, noted that in their experience, recuperation in one's home, especially if there was loving care and pure food available, made more difference than any climate, and was more healing than relocating people to isolated facilities. Dr. Lovejoy, on the other hand, asserted that it was well-known that sanitorium care was best for tuberculosis patients and "the site chosen should be conducive to mental rest and upbuilding." 42 Above all, however, Pohl argued that more money and concerted effort must be put towards stopping the spread of the disease. The effort must be great and active in every state, she said. Dr. Lovejoy's statement in particular hints at the fact that some of her colleagues did not believe the public health effort towards fighting tuberculosis was a worthwhile cause.

Yet those in Lovejoy's camp were gaining ground. The People's Institute, an early social service agency in the city, developed a medical clinic and free dispensary in 1907 on West Burnside and 4th streets. They worked together with the Visiting Nurse Association, a volunteer organization of nurses whose primary mission at the time was fighting tuberculosis through treatment, education, and containment. The work of the Visiting Nurse Association would hasten the relocation of the Poor Farm and shape the Farm's historical legacy.

In 1909 the People's Institute joined forces with the University of Oregon Medical School, and also invited the Visiting Nurse Association to use some of the expanded rooms at the Institute for a tuberculosis clinic. They accepted the offer and the VNA, in conjunction with the Free Dispensary, held tuberculosis clinics for adults and

\footnotetext{
${ }^{42}$ Ibid, 48
} 
children twice a week, and a children's clinic on Saturday mornings. These clinics focused on both aid and treatment for the afflicted and education about how the disease was spread. Instruction in how to care for one's self and how to best prevent spreading the disease to others were also a feature of the Milwaukie Heights sanitorium. In addition, the increased emphasis on stopping the spread of disease through proper hygiene reflected a growing belief in an individual's personal responsibility to maintain a sanitary lifestyle. At the Free Dispensary/VNA tuberculosis clinic, "children were kept under constant supervision," and the VNA carried out follow up work in many cases. ${ }^{43}$ This follow up work was beneficial to the individual families, but it also allowed authorities to

${ }^{43}$ Valentine Prichard, "Origin and Development of Settlement Work in Portland, Including Free Medical Work, a report of the Auspices of the People's Institute" (1939), page 15-16. Public Health in Oregon: Discovering Historical Data 236, http://digitalcommons.ohsu.edu/public-health-data/236 
track, contain, and instruct patients.

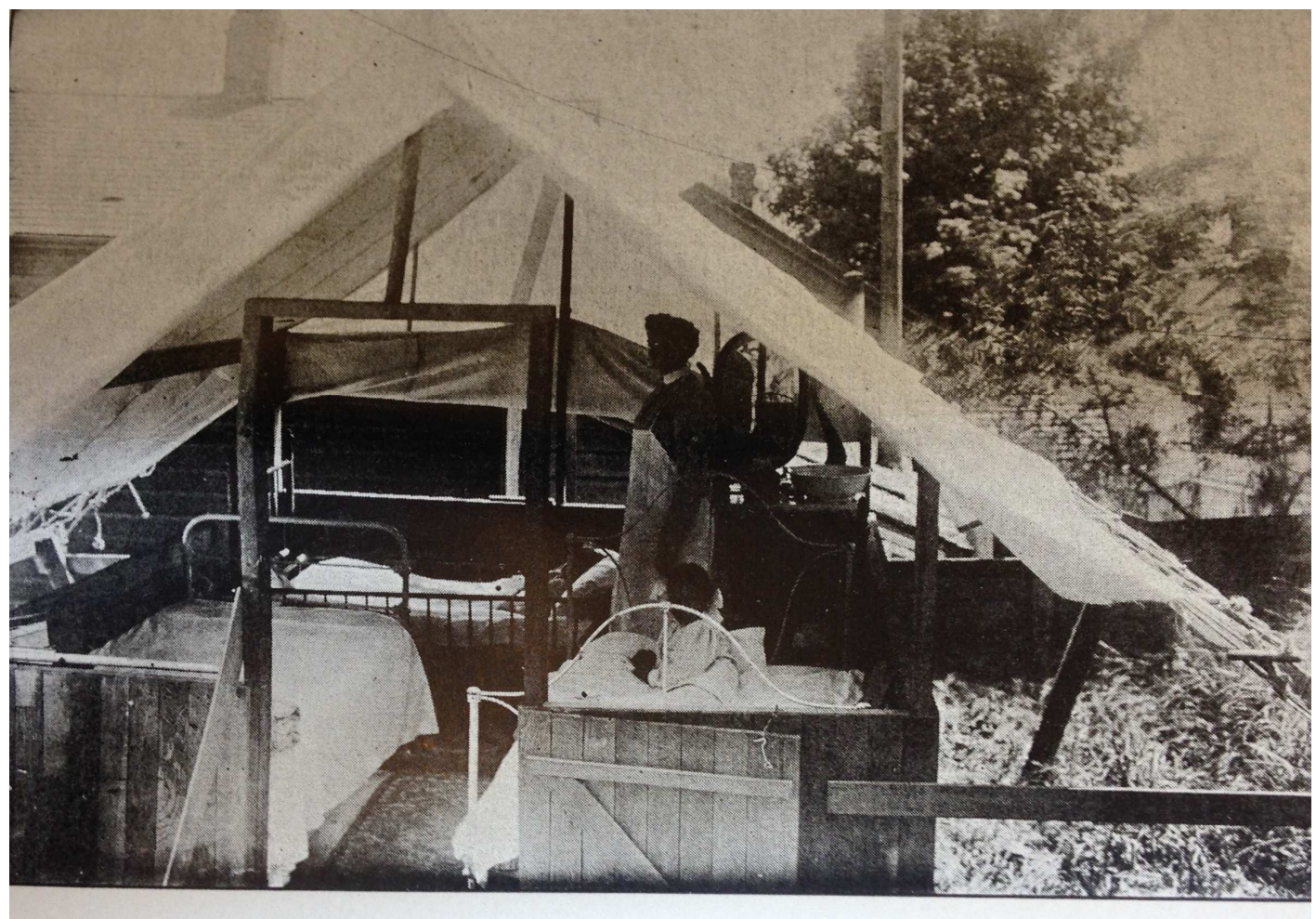

One of the V. N. A. Tents Provided for a Tubercular Family.

Figure 17. Visiting Nurse Association Tubercular Tent, c. 1910

Photo of a tent set up by the Visiting Nurse Association for a family suffering from tuberculosis, c. 1910. Included in the March 31, 1910 VNA Annual Report. [Portland Archives and Records Center]

Dr. Lovejoy credited stricter control and enforcement of isolation as beginning to stem the tide of tuberculosis deaths. For the first six months of 1909, the Board of Health reported fewer deaths than during same period in the preceding two years. This was especially significant, Lovejoy wrote, because Portland was rapidly growing, thus a decrease not only in relative deaths but also in total deaths was especially striking. Regarding tuberculosis in particular, Lovejoy wrote: "For many years tuberculosis has been the chief cause of death but a gradual awakening to the nature and possibilities of 
prevention and cure of this disease has come and concerted efforts are being made for its suppression. ${ }^{\prime 44}$ In the first half of 1907,113 deaths from tuberculosis were reported. In 1908 that number rose to 117 but the following year it dropped to 100 . The decrease may have been modest but considering the population growth of the time it seemed to imply some progress was being made.

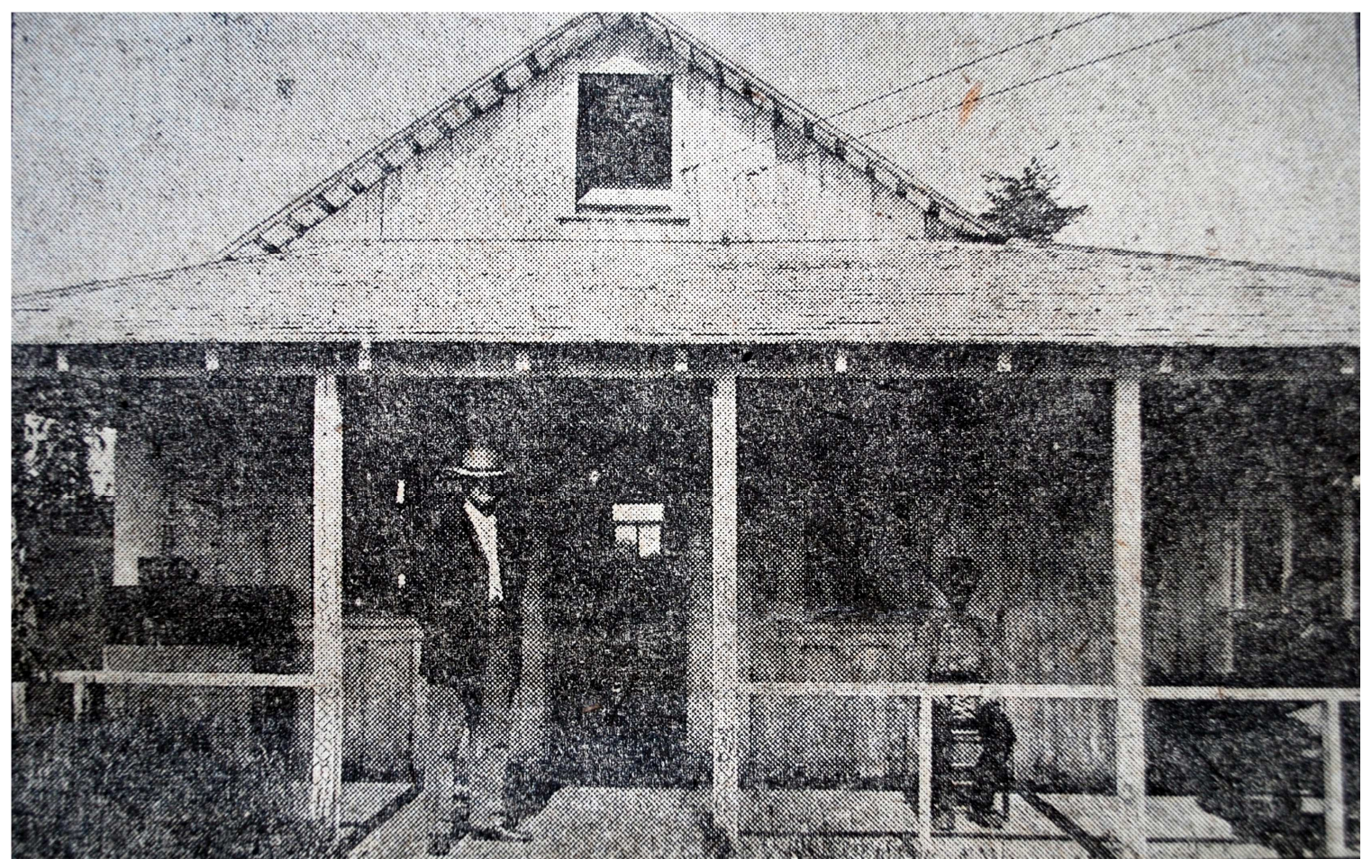

Figure 18. TB Ward at the Poor Farm, c. 1907 This photo is taken from the June 9, 1907 Oregon Journal. [Courtesy of Donald Nelson].

Records describing the tuberculosis ward of the Poor Farm were conflicting. On the one hand, the Taxpayers' League visited the "Poor Farm proper, County Hospital and the Superintendent's dwelling [and] a small, detached building for tuberculosis patients,

${ }^{44}$ Report of the Portland Board of Health, June 1909, page 4. 
burns, etc." and all were found "in excellent order and very clean." ${ }^{45}$ The League found that the County Hospital was not crowded and was in good condition, though admittedly the wooden building was outdated. They did not recommend building a new hospital. On the other hand, Joseph Gaston's nearly contemporaneous history of Portland praised the opening of a new County Hospital on SW 2nd and Hooker Streets in 1909. Gaston's account provides insight into the minds of some prominent men of the era. According to the wealthy railroad magnate, the County Hospital at the Poor Farm had provided "indifferent care in wards connected with the almshouse." ${ }^{46}$ With the new hospital, Gaston wrote, "the old time hit or miss methods of nursing gave place to scientific and cleanly regulations.” The County Physician E.P. Geary had implemented modern standards of healthcare, including applying specialized practices for different conditions.

Along with the new treatment standards, new facilities were also needed in order to provide the best care. The county commissioners therefore appropriated funds to purchase grounds and equipment for a hospital "away from the environment of the poorhouse." The new hospital was called Multnomah Hospital, "the word county being dropped, and with it the stigma of pauperism so unnecessary and so offensive to the unfortunate who, by reason of sickness, is obliged to seek charity." ${ }^{47}$ Gaston's description of the County Hospital and Poor Farm belied his and the county commissioners' opinion that being sick and poor was a worthy reason to receive aid without shame, whereas

\footnotetext{
45 “Praises Poor Farm Taxpayers' League Investigating Committee Reports. Advises Few Changes." Oregonian, November 6, 1907.

${ }^{46}$ Joseph Gaston, Portland, Oregon: Its History and Builders, vol I. (Chicago S. J. Clark Publishing, 1911): 453.

${ }^{47}$ Ibid 453.
} 
being poor, by itself, was not. For that reason, he supported separating the hospital from the Poor Farm.

With the county hospital in South Portland, the old Poor Farm hospital was becoming obsolete. Throughout the purchase and opening of the Multnomah Hospital, the tuberculosis ward on the Poor Farm was still in operation, as was the Milwaukie Heights sanitorium. In describing the Milwaukie facility, Gaston reflected the modern, public health thinking on tuberculosis. He wrote that, "if the patient has courage and good judgement, he has a right to get well, or at least to greatly prolong his life. The modern sanitorium removes him from the cares of home and teaches him not only to prevent reinfecting himself, but to avoid infecting others." ${ }^{48}$ Gaston was relying on sanitorium Dr. A. E. Pierce's thoroughly modern view, but the opinion relied on the old worthy and unworthy paradigm. The man who was willing to take his treatment seriously, and to play by the rules of the new public health regime, had a right to improve.

Further, the understanding of the patient's responsibility was steeped in morality. The Milwaukie sanitarium wrote in its official rules and regulations that just because one person in a family had consumption did not mean anyone else must contract it. "If they do take it, it is because someone has been careless in not observing the rules set forth for the consumptives to follow, and not because it is inherited or unavoidable. Consumption is positively a preventable disease, and the family that allows it to spread from one of its members to another are either ignorant or careless in observing the rules of health and prevention of disease." ${ }^{49}$ These statements reflected a growing belief in the personal

\footnotetext{
48 Ibid 454.

49 Ibid 455.
} 
responsibility of individuals to practice good hygiene, and as the ultimate arbiters of their own health.

In this era of increased media, government, and popular focus on tuberculosis and sanitary conditions, a visit to the Poor Farm from the Visiting Nurse Association took on heightened significance. Even after the Multnomah County Hospital in South Portland opened, the Poor Farm and County Hospital continued to house indigent and treat patients. The Visiting Nurse Association, which had advocated for the new hospital, counted the opening of the facility as a victory, but urged members to continue monitoring the conditions at the Poor Farm. The organization's eight annual report, for the year ending in March, 1910, reported: "First—and those who had visited the old county hospital can appreciate the importance of this accomplishment—our Multnomah Hospital is a living reality.. . . but we are still interested in what has been left behind at the old site, and the members are urged to visit the old county farm as often as possible." ${ }^{50}$ These were the circumstances under which the infamous VNA condemnation of the Poor Farm, especially the tuberculosis ward, occurred.

In November, 1910, The Oregon Journal ran an explosive report on conditions at the Hillside farm. A front page feature on November 19 and 20 described in lurid details the unsanitary conditions of the Farm, particularly the TB ward. "Committees from charitable organizations of the city" had visited several times, The Oregon Journal reported, and reportedly their agitation resulted in the county commissioners authorizing

${ }^{50}$ Visiting Nurse Association Report for the Year Ending March 31, 1910, page 11. Portland Archives and Records Center, Portland, OR. 
improvements. ${ }^{51}$ The newspaper reported that "many complaints" had come before the county court and the county physician, Dr. E.P. Geary, before the improvements were ordered.

According to this article, which primarily addressed the tuberculosis wards, cots were filthy, the entire place was understaffed, and a male nurse continually made advances toward a female patient. Tuberculosis patients were required to expectorate tubercular sputum into unsanitary open cuspidors, and for those too weak to do so, "Beards were allowed to grow and become plastered with tuberculosis sputum." ${ }^{12}$ Such conditions ran afoul of the modern medical recommendations for proper tuberculosis hygiene.

The Visiting Nurse Association was the only organization the newspaper named, although The Oregon Journal claimed that staff physicians and visiting doctors confirmed the veracity of their reports. In addition to the unsanitary conditions on the TB ward, the report complained tuberculosis patients with advanced disease came into town and mingled with the general public, to which the suspect male nurse said he could not control them. Further, the paper reported, they used tobacco and alcohol in town. According to the article, county officials, when confronted with the information, claimed ignorance of the state of affairs.

Prone to bombastic prose, The Oregon Journal led with eye-catching headlines like "Death of patients in tubercular wards hastened by the stench in unsanitary quarters — nurses leave them," and " Bed clothing dirty and full of bacilli," and "Rain

51 "Startling Conditions at Poor Farm," Oregon Journal, November 19, 1910, page 1.

52 Ibid. 
leaks through roof on unfortunates—consumptives with others." ${ }^{\text {"53 }}$ According to The Oregon Journal, organized charity associations demanded that an investigation into responsibility be held and "that repairs be not attempted, but that new and sanitary quarters be provided at county expense and adjoining the county hospital if possible. ${ }^{54}$ "The committees have reported that the place cannot be made decent," The Oregon Journal reported. Unfortunately, other than the Visiting Nurse Association, the articles did not name the organizations reportedly making the claims of abuse and filth. While some of the problems the article mentioned were directly related to the care of the patients, others had to do with the staff's failure to control the inmates properly.

The article went on to quote Dr. Ray Matson at length, saying that in fact authorities did know about the abominable conditions, as he had informed them the previous spring that he was concerned with the presence of infection. In addition, he said that the county authorities in charge told him it was not a place to treat consumptives but a place for them to die. The Visiting Nurse Association reportedly lamented that the consumptives were "forced to see people die in cheerless quarters and unsanitary surroundings when a little care exerted in time might have restored them to health and usefulness." A representative of the The Oregon Journal reportedly visited the farm and confirmed all conditions. The one male nurse was drinking, and reportedly claimed he had to drink to endure the terrible scenario.

Dr. Matson reportedly recommended a change of location, construction of a tuberculosis pavilion adjoining the county hospital (by this point, on SW 2nd and Hooker

53 "Filthy Conditions at Poor Farm Shock Portland," Oregon Journal, November 20, 1910, page 1.

${ }^{54}$ At this time, the County Hospital would have referred to the new Multnomah Hospital on Southwest Second and Hooker Streets. 
Streets), a diet kitchen where nutritious meals could be prepared according to the most current medical guidelines, and hiring people who are were trained in treating tuberculosis. The charitable organizations agreed with these recommendations and also noted that Matson said the changes would cost $\$ 1,600$, and "there will be no more danger to public health." Such a fix would have been far less expensive than the purchase of the Troutdale farm.

Superintendent D. D. Jackson, who succeeded Superintendent Courtney, was quoted as saying the criticisms were true but they were doing the best they could with what they had. The buildings were too old and "we will not occupy them very long." People quit all the time too, he claimed. Jackson also said that Matson should not have gone to the papers without telling him first, that he knew Matson was on staff but "[I] don't believe I have ever seen him," and also that Geary had not been there in six months. Jackson's comments hint that County Physician Geary was putting all his time and energy into the Multnomah Hospital, and neglecting the wards of the Poor Farm. Further, Jackson reminded the reporter that work had already begun on the new Poor Farm in Troutdale and implied that as a result, not much effort was going into the Poor Farm maintenance. Thus the argument can be made that the reason conditions at the Poor Farm were so dire was because officials had already given up on the place, and not the other way around.

Surprisingly, The Oregonian did not publish any part of this report by the Visiting Nurse Association. In fact, that paper only published something of a rebuttal. On November 11, The Oregonian ran an article entitled "All Are Content: Tubercular 
Patients at Poor Farm Make No Complaint." A few days later, The Oregonian reported that in fact the superintendent admitted that the conditions were true and enumerated steps that would be taken to render the facility more sanitary. At this time, the farm housed 200 inmates - far more than the property was intended to house.

Due to the sensational nature of journalism in the early twentieth century, as well as the lack of author bylines and the fairly common practice of selling space for opinion pieces without acknowledging the fact that such sections are paid advertisements, it is difficult to parse out the truth of conditions at the Multnomah County Poor Farm in the first decade of the twentieth century. ${ }^{55}$ Regardless of the conditions at the farm, however, the 1910 organized charity visits could not have been the sole cause for the move, as the county began looking for a new poor farm location on the east side of Portland as early as $1908 .^{56}$

Since the Poor Farm's relocation, the story has been largely lost. The scant historical research sources on the original Poor Farm places the Visiting Nurse Association visit at the center of the 1911 relocation. But in reality, by the time the VNA made its condemnation, the county had already begun building the Troutdale farm. Thus the women of the VNA, as well as the medical community, may have felt genuine compassion for the tubercular residents of the Poor Farm, but their altruism was not the primary force in the Poor Farm's relocation.

\footnotetext{
${ }^{55}$ For a discussion of influence-buying in nineteenth-century newspapers, see Richard White, Railroaded: Transcontinental Railroads and the Making of Modern America (New York: W. W. Norton, 2011) and Richard Kaplan Politics and the American Press: The Rise of Objectivity, 1865-1920 (Cambridge: Cambridge University Press, 2002).

56 "Poor Farm on East Side," Oregonian, July 9, 1908.
} 


\section{$\underline{\text { Epilogue }}$}

The Gresham Outlook reported that the old farm sold for $\$ 154,000$, and

the new farm cost $\$ 100,000$, so the county made a profit on the move, though it may have been a wash when figuring in the costs of relocation and operating the new Multnomah Hospital. In November 1911, 211 Poor Farm residents were moved to the new farm in Troutdale. A long legal battle ensued over ownership of the old Poor Farm property, with several men claiming to own a three-fifths share. Eventually, the courts awarded ownership to B. M. Lombard. After Lombard failed to make payments on the land, the county foreclosed and reclaimed ownership. In 1922, Multnomah County gifted it to the City of Portland to be used as a park. The City first turned the southern portion of the farm, where most of the buildings had stood, into a golf course. Then in the 1950s, the new Oregon Zoo was constructed on the site. Today the facilities on the former Poor Farm land, including the Hoyt Arboretum, the Oregon Zoo, and World Forestry Center, are some of the city's most popular destinations for tourists and locals alike.

But adjacent to these attractions, in downtown Portland, lives another defining feature of the city: a large, highly-visible homeless population. In private conversation, in city council forums, in closed door meetings of business interests, in editorials, and in online comment sections, Portlanders today debate what to do with the homeless. While the city offers relatively favorable conditions for homeless people - and a vocal contingent of homeless advocates - some Portlanders dismiss the unhoused population as lazy, entitled, unwilling to work, and therefore undeserving of aid. Moreover, business interests and investors argue the homeless presence scares away customers and 
discourages potential investment. Recently, Columbia Sportswear, one of Oregon's largest companies, made headlines when The Oregonian ran an opinion piece by Columbia's CEO Tim Boyle, in which he stated he was considering relocating some of the company's downtown offices because the homeless population "hassled, harassed and threatened" his employees. ${ }^{1}$ Homeless advocates and supporters responded with a protests against the company that closed the flagship store for part of one day. ${ }^{2}$ The issues raised and viewpoints taken show striking parallels to the debate around what to do with destitute Portlanders a century earlier.

Perhaps the most obvious parallel can be seen in the case of the nonprofit organization Right 2 Dream Too. The organization, which is a community-run, safe sleeping facility, opened on West Burnside and 4th Ave, a prominent downtown location, in 2011. Unlike tent clusters set up on right-of-ways and freeway overpasses, Right 2 Dream Too is a legally-functioning nonprofit. Yet the community was never popular with its neighbors, and business interests and the tourism industry pressured the city government to move R2D2, as community members call it, out of the downtown core. Over the next five years, the city would seek a new place to locate the facility. Neighborhood opposition thwarted negotiations on the first three locations, until finally, in July 2017, R2D2 moved to a city-owned parking lot on the east side of the Willamette River, adjacent to a railroad line. Even this location, however, is only temporary: as of

\footnotetext{
${ }^{1}$ Tim Boyle, "Tim Boyle: Portland leaders must address safety issues downtown (Guest opinion), Oregonian/OregonLive, November 10, 2017.

2 Allan Brettman, "Columbia Sportswear closes downtown store Saturday as protesters gather," Oregonian/OregonLive, December 2, 2017.
} 
summer 2017 , the city is permitting use of the land for up to two years. ${ }^{3}$

The decision is merely the city's most recent move in a century-old struggle over placement of its indigent. Today's lawmakers are debating affordable housing measures, extension of former Mayor Charlie Hales' declaration of a Housing State of Emergency, and the legality of camping on the streets. Roughly fifteen years ago, similar issues involved the homeless community Dignity Village and the legality of the sit-lie ordinance. ${ }^{4}$ The questions of who should receive assistance, where, and in what manner have long been alive and well in Portland.

Portland is not the only city facing homelessness, nor is today's situation identical to that of one hundred years ago. It is true, much to the chagrin of those Americans who do not believe the government should provide welfare support, that more safety net services exist in the early twenty-first century than did in the early twentieth century. Further, the American economy, and Portland's economy, have changed. With the exception of farm labor, unskilled seasonal work no longer is a driving force of economic growth. ${ }^{5}$ Yet some facts remain constant. Now, as in centuries past, many of the

3 "Right 2 Dream Too leaves downtown, welcome mat extended by Moda Center and Lloyd District," Oregonian/OregonLive, June 15, 2017; Molly Harbarger, "Right to Dream 2: A Timeline," Oregonian/OregonLive, April 6, 2017.

${ }^{4}$ Sit-lie ordinance was a highly-controversial city ordinance intended to keep downtown sidewalks clear. It primarily affected homeless people and the U.S. District Court declared it unconstitutional in 2009. See "Sit-lie debate over Portland homelessness will return to Oregon legislature," Oregonian/OregonLive, December 16, 2013. Dignity Village is another nonprofit organization that functions as a shelter and resource center for people experiencing homelessness. Dignity Village began as a homeless encampment in downtown Portland, which also faced pressure to move. Unlike Right 2 Dream Too, however, Dignity Village was originally operating without the permission of property owners, and city officials pushed the camp around various downtown locations before reaching a negotiation wherein the city would recognize the camp's right to occupy a plot of land by the Portland airport, roughly ten miles from the city center. For more on Dignity Village, see Thacher Schmid, "Dignity Village's evolution from protest to a lasting home," KGW, June 20, 2017.

${ }^{5}$ A discussion of contemporary American farm labor is relevant, but beyond the scope of this thesis. 
homeless, and non-homeless receiving government assistance, come from the following groups: uneducated and unskilled men and women, mentally and physically disabled people, those struggling with mental illness, addiction, and alcoholism, and the elderly. Even with increased safety net programs, such as social security, these members of society are still at risk for poverty. Racial and ethnic minority groups are also more likely to experience poverty, both in Portland and nationwide. ${ }^{6}$

Portland's West Hills, including Washington Park, are a tourist destination and a point of civic pride. But the people who were displaced in order to create this crowning jewel deserve to have their story told. My research has real implications for the city today, as number of homeless and displaced residents continues to grow, and city leaders extend the Housing State of Emergency indefinitely. ${ }^{7}$ In a 2016 city council work session, former Mayor Hales summed up the tensions inherent in efforts to alleviate Portland's poverty and homelessness. "We want to live in a beautiful, livable city with a high quality of life," he said, "but we have a lot of people who are on the streets and need

6 "Poverty in Oregon: Six Charts," Oregon Center for Public Policy, updated October 22, 2015. https://www.ocpp.org/media/uploads/pdf/2015/10/fs20151022-poverty-oregon-charts-fnl.pdf. According to the Oregon Center for Public Policy, in 2014, 16.6 percent of Oregonians lived in poverty. The numbers by race and ethnicity were as follows: African Americans at 38.3 percent, Pacific Islanders at 33.2 percent, Native Americans at 28.1 percent, Latinos at 26.4 percent, Asians at 16.3 percent, and whites at 13.9 percent.

"Poverty in Multnomah County, 2014," Report, Multnomah County Department of County Human Services, April 2014. https://multco.us/file/34343/download. People of color in Multnomah County are also more likely to live in poverty than white residents. A 2014 county report found that while people of color make up 28 percent of Multnomah County residents, they account for 44 percent of those living poverty. "Poverty in Multnomah County," Report (2014): 17.

Suzanne Macartney, Alemayehu Bishaw, and Kayla Fontenot, "Poverty Rates for Selected Detailed Race and Hispanic Groups by State and Place: 2007-2011, American Community Survey Briefs (2013), https://www.census.gov/prod/2013pubs/acsbr11-17.pdf. Nationwide, from 2007 to 2011, Americans identifying as Black or African American, American Indian or Alaska Native, Native Hawaiian and other Pacific Islander, and two or more races were more likely to be living in poverty. So were Hispanic and Latino-identified Americans, regardless of racial identification. Asian Americans and white Americans experienced a similar rate of poverty.

${ }^{7}$ Floum, Jessica. "Portland City Council Extends Renter Protection and 'Housing Emergency"” Oregonian/OregonLive, October 4, 2017. 
help." At a time of unprecedented exposure for the city, it behooves Portlanders to ask what our past can teach us about displacement, identity, and development—issues that resonate so loudly today.

${ }^{8}$ Jim Redden, "Hales: Portlanders Should Tolerate More Homeless Camping," Portland Tribune Online (February 8, 2016). 


\section{$\underline{\text { Archival Sources }}$}

Admissions Ledger of the Multnomah County Poor Farm and Hospital. Vol I (19001908). Multnomah County Archives, Portland, OR.

"An Act to Provide for Park Commissioners, and the Acquisition of Lands for Parks, and the Management Thereof' February 17, 1899, reprinted in the Report of the Park Board for 1901, Portland Archives and Records Center.

Baty, Captain Charles. Police report, April 2, 1909. Portland Archives and Records Center.

Board of Charities folder. Portland Archives and Records Center.

Board of Health, Portland. "Office of the Board of Health of Portland, Annual Report, 1907," Health Department, (1907), page 3. Public Health in Oregon:

Discovering Historical Data. 227.

Board of Health, Portland. "Report of the Portland Board of Health." June 1909. Portland, OR. Health Department, "Office of the Board of Health of Portland, Monthly Report, June 1909" (1909). Public Health in Oregon: Discovering Historical Data. 232. http://digitalcommons.ohsu.edu/public-health-data/232

Carr, E. J. E. J. Carr, County Clerk to Mayor Harry Lane, April 17, 1909. Letter. From Portland Archives and Records Center.

Chamber of Commerce, Portland. Chamber of Commerce Bulletin for July 1904. Portland: Portland Chamber of Commerce, 1904.

Chamber of Commerce, Portland. "Portland Chamber of Commerce Bulletin." Portland, OR. February 1910. Portland Archives and Records Center.

Grubbs, J. C., and Carpenter, H. “'Locality as Affecting Consumption” The Oregon Medical \& Surgical Reporter 1, no. 4 (1870). In Public Health in Oregon: Discovering Historical Data, a collection of Oregon Health and Science University. http://digitalcommons.ohsu.edu/public-health-data/313.

House, William. "Transactions of the Thirty-Third Annual Meeting of the Oregon State Medical Association, 1907" (1907), In Public Health in Oregon:

Discovering Historical Data. http://digitalcommons.ohsu.edu/public-healthdata/10

Journals of the Board of County Commissioners. Microfilm, Film File 1, Commissioners 
Journal (County) \& Warranty Register 1855-1871. Multnomah County Archives, Portland, OR.

Lewis, Ion. Ion Lewis to John Charles Olmsted. Letter. September 4, 1908. In Portland Park Board Meeting Minutes, 412-486. Portland Archives and Records Center.

Olmsted, John Charles. John Charles Olmsted to Ion Lewis. Letters. December 6, 1907. In Portland Park Board Meeting Minutes, 412-486. Portland Archives and Records Center.

Ordinance 42141, City of Portland, November 29, 1922. City of Portland Archives and Records Center.

Oregon Death Indexes, 1903-1970. Salem, OR, USA: Oregon State Library www.ancestry.com

Oregon Health and Science University. Public Health in Oregon. Brochure. Oregon Health and Science University Library, Archives Display, Portland, Oregon. Summer 2017.

Park Board, Portland. "Report of the Park Board for 1904, Including the Report of the Olmsted Brothers Firm for a System of Parks and Boulevards." Portland, OR. 1904. Portland Archives and Records Center. Record Date: 12/31/1904 Record Number: AF/7317. container: Parks \& Recreation, Collected Reports and Studies

Park Board, Portland. "Report of the Park Board for 1901." In Portland Archives and Record Center. Record Number APF/173, Record Date 03/01/1902, Portland, OR

Pierce, E. A. "Sanatorium Treatment of Tuberculosis in the Northwest," in House, William M.D., "Transactions of the Thirty-Third Annual Meeting of the Oregon State Medical Association, 1907" (1907), 48. Public Health in Oregon: Discovering Historical Data, http://digitalcommons.ohsu.edu/public-health-data/10

Portland Directory for 1866. Portland, OR: S. J. McCormick, 1866.

Portland, Oregon: The City of Roses. Portland,OR: The Portland Post Card Company, 1907

Portland, Oregon: The City of Roses. Portland, OR: The Portland Post Card Company, 1907.

Visiting Nurse Association. Annual Report of the Visiting Nurse Association, 1903-1912. Board of Charities files, City of Portland Archives and Records Center. 


\section{Bibliography}

Abbott, Carl. Portland: Planning, Politics, and Growth in a Twentieth Century City (University of Nebraska Press: Lincoln), 1983.

Abbott, Carl. The Great Extravaganza: Portland and the Lewis and Clark Exposition. Portland, OR: Oregon Historical Society, 2004.

Abbott, Carl. "The 1905 Lewis \& Clark Exposition.” Lecture at Architectural Heritage Center, Portland, Oregon. November 12, 2016.

Abramovitz, Mimi. Regulating the Lives of Women: Social Welfare Policy from Colonial Times to the Present. Rev. ed. Boston: South End Press, 1996.

Alborn, Denise. "Crimping and Shanghaiing on the Columbia River," Oregon Historical Quarterly 93 vol. 3 (1992): 262-291.

Aurand, Mary Elizabeth. "The Floating Men: Portland and the Hobo Menace, 18901915." master's thesis, Portland State University, 2016. http://pdxscholar.library.pdx.edu/open_access_etds/2400/.

Blackford, Mansel. The Lost Dream: Businessmen and City Planning on the Pacific Coast, 1890-1920. Columbus, OH: Ohio State University Press, 1993.

Epstein, William M. The Dilemma of American Social Welfare. New Brunswick, N.J.: Transaction Publishers, 1993.

Breul, Frank R., and Diner, Stephen J., eds. Compassion and Responsibility: Readings in the History of Social Welfare Policy in the United States. Chicago: University of Chicago Press, 1980.

Gaston, Joseph. Portland, Oregon: Its History and Builders, vol I. (Chicago: S. J. Clark Publishing, 1911).

Harrington, Michael. The Other America: Poverty in the United States. New York: Simon and Schuster, 1962. 
Hawkins III, William. The Legacy of the Olmsted Brothers in Portland. Portland, OR: published by author, 2014.

Herndon, Ruth Wallis. “'Who Died an Expence to This Town:' Poor Relief in Eighteenth-Century Rhode Island," In Down and Out in Early America, edited by Billy G. Smith, 135-162. University Park, PA: Pennsylvania State University Press, 2004.

Foucault, Michel. Discipline and Punish: The Birth of the Prison. Translated by Alan Sheridan, 1997. Reprint, New York: Second Vintage Books 1995. [originally published in France in 1975 as Surveiller et Punir: Naissance de la Prison].

Guest, Geoffrey. “The Boarding of the Dependent Poor in Colonial America." Social Service Review 63 no. 1 (1989): 92-112.

http://www.jstor.org.proxy.lib.pdx.edu/stable/30012002.

Horowitz, David. “Social Morality and Personal Revitalization: Oregon's Ku Klux Klan in the 1920s" Oregon Historical Quarterly 90, no 4 (winter 1989): 365-384.

Kaplan, Richard. Politics and the American Press: The Rise of Objectivity, 1865-1920 Cambridge: Cambridge University Press, 2002.

Katz, Michael. Poverty and Policy in American History. New York: The Academic Press, 1983.

Katz, Michael. Improving Poor People: The Welfare State, the "Underclass" and Urban Schools As History. Princeton: Princeton University Press, 1995.

Katz, Michael. In the Shadow of the Poor House: A Social History of Welfare in America. New York: Basic Books, 1986.

Katz, Michael. The Undeserving Poor: America's Enduring Confrontation with Poverty. New York: Oxford University Press, 2013.

Leiby, James. “Charity Organization Reconsidered.” Social Service Review 58, no. 4 (1984): 523-38. http://www.jstor.org.proxy.lib.pdx.edu/stable/30011759

MacColl, E. Kimbark. The Shaping of a City: Business and Politics in Portland, Oregon, 1885-1915. Portland, OR: printed by the author, 1976.

Marshall, Joan E. "The Charity Organization Society and Poor Relief for the Able-bodied Unemployed: Lafayette, Indiana, 1905-1910”. Indiana Magazine of History 93, 
no. 3 (1997): 214-243. http://www.jstor.org.proxy.lib.pdx.edu/stable/27792018

McNeur, Catherine. "Parks, People, and Property Values: The Changing Role of Green Spaces in Antebellum Manhattan." Journal of Planning History 16, no. 2 (2016): 98-111. https://doi.org/10.1177/1538513216657563

McNeur, Catherine. Taming Manhattan: Environmental Battles in the Antebellum City. Cambridge, MA: Harvard University Press, 2014.

Munk, Michael. "Coxey’s Army,” In Oregon Encyclopedia. Published by Oregon Historical Society and Portland State University, 2017. https://oregonencyclopedia.org/

Nash, Gary B. "Poverty and Politics in Early American History." In Down and Out in Early America, edited by Billy G. Smith, 1-37. University Park, PA: Pennsylvania State University Press, 2004.

Nash, Gary B. "Poverty and Poor Relief in Pre-revolutionary Philadelphia". The William and Mary Quarterly 33, no. 1 (1976): 3-30. doi:10.2307/1921691.

Nesbit, Sharon and Hills, Tim. Vintage Edgefield: A History of the Multnomah County Poor Farm and McMenamins Edgefield. Portland, OR: McMenamins, 1995.

Noel, Thomas J., and Norgren, Barbara S. Denver: The City Beautiful and its Architects, 1893-1941. Denver: Historic Denver Inc., 1987.

Olasky, Marvin. The Tragedy of American Compassion. Washington, D.C.: Regnery Publishing, 1992.

Orloff, Chet. "Portland Park Blocks." In Oregon Encyclopedia. Published by Oregon Historical Society and Portland State University, 2017. https://oregonencyclopedia.org/

Pimpare, Stephen. Poverty in America: A People's History of Poverty in the United States. New York: The New Press, 2008.

Pimpare, Stephen. The New Victorians: Poverty, Politics and Propaganda in Two Gilded Ages. New York: The New Press, 2004.

Prichard, Valentine, "Origin and Development of Settlement Work in Portland, Including Free medical Work (a report of the Auspices of the People's Institute)." (1939) In Public Health in Oregon: Discovering Historical Data. 236. http://digitalcommons.ohsu.edu/public-health-data/236 
Smith, Billy G. “'The Best Poor Man's Country'?” In Down and Out in Early America, edited by Billy G. Smith, xi-xx. University Park, PA: Pennsylvania State University Press, 2004.

Stein, Harry. "The Oregonian.” In Oregonian Encyclopedia. Published by the Oregon Historical Society and Portland State University, 2017. https://oregonencyclopedia.org/articles/oregonian/\#.WdmCJdOGORs

Smits, Katherine and Jansen, Alix. "Staging the Nation and Expos and World's Fairs," National Identities 14 no. 2 (2012): 173-188.

Scott, Harvey Whitefield. History of Portland, Oregon. Portland, OR: D. Mason, Co., 1890.

Stroud, Ellen. "Troubled Waters in Ecotopia: Environmental Racism in Portland," Radical History Review 74 (1999): 65-95

Sykes, Alan. “Harold Farrow's Splendid Portland," Oregon Historical Quarterly 99 no. 1 (1998): 51-52. http://www.jstor.org.proxy.lib.pdx.edu/stable/20614869.

Teague, Ed. "The Apartment Building in Portland: 1900-1930: An Introductory Survey." Lecture at Architectural Heritage Center, Portland, Oregon. November 5, 2016.

Trattner, William. From Poor Law to Welfare State: A History of Social Welfare in America. New York: The Free Press, 1994.

White, Richard. Railroaded: Transcontinental Railroads and the Making of Modern America. New York: W. W. Norton, 2011. 